$$
\text { UNIVERSIDADE DE SÃo PAULO }
$$

Faculdade de Filosofia, Letras e Ciências Humanas

Departamento de Letras Orientais

Programa de Pós-Graduação em Estudos Judaicos

Edson Magalhães Nunes Júnior

\title{
Uma INTROdução geral À Poesia Hebraica Bíblica
}

São Paulo

2012 


\author{
UNIVERSIDADE DE SÃO PAULO \\ Faculdade de Filosofia, Letras e Ciências Humanas \\ Departamento de Letras Orientais \\ Programa de Pós-Graduação em Estudos Judaicos
}

Edson Magalhães Nunes Júnior

Uma InTROduçÃo geral À PoEsia Hebraica Bíblica

Dissertação apresentada à Faculdade de Filosofia, Letras e Ciências Humanas (Departamento de Letras Orientais) da Universidade de São Paulo para obtenção do título de mestre em Estudos Judaicos. Orientadora: Professora Doutora Suzana Chwarts.

São Paulo

2012 


\author{
UNIVERSIDADE DE SÃO PAULO \\ Faculdade de Filosofia, Letras e Ciências Humanas \\ Departamento de Letras Orientais \\ Programa de Pós-Graduação em Estudos Judaicos
}

Edson Magalhães Nunes Júnior

\title{
UMA INTROdução GeRAL À PoEsia Hebraica BíBlica
}

Dissertação apresentada à Faculdade de Filosofia, Letras e Ciências Humanas (Departamento de Letras Orientais) da Universidade de São Paulo para obtenção do título de mestre em Estudos Judaicos. Orientadora: Professora Doutora Suzana Chwarts.

Aprovado em:

\section{BANCA EXAMINADORA}

Profa. Dra. Suzana Chwarts - USP (Universidade de São Paulo) Julgamento: Assinatura:

Prof. Dr. Reginaldo G. de Araújo - USP (Universidade de São Paulo) Julgamento: Assinatura:

Prof. Dr. Reinaldo W. Siqueira - SALT (Seminário Adventista LatinoAmericano de Teologia)

Julgamento: Assinatura:

São Paulo 
À minha esposa, Vanessa, inspiração das inspirações. 


\section{AGRADECIMENTOS}

Ao Criador.

À Vanessa Nunes, minha companheira.

Ao Daniel e Yossef, verdadeiros poemas de amor.

Aos meus pais, Edson e Rose Nunes, imagens dEle, que não somente apoiaram, mas sustentaram meu caminho até aqui.

Ao Eder e Elson Nunes, pelo incentivo.

À Dra. Suzana Chwarts, pela crença em mim, no meu trabalho, que chega a ser uma paráfrase da fé abraâmica.

Ao Dr. Reinaldo Siqueira, modelo acadêmico e um segundo pai.

Ao Dr. Wagner Kuhn, o amparo e a força nos momentos mais difíceis.

Ao Leonardo Gonçalves, amigo chegado como um irmão.

Ao Dr. Murray Salisbury, que plantou a semente da Poesia Hebraica Bíblica em minha mente.

À Luciana Tavares, pela edição e correção de todo o material em tempo recorde.

À Associação Paulistana da IASD, na pessoa do Pr. Sidionil Biazzi, pelo apoio. Ao UNASP, nas pessoas do Pr. Paulo Martini, do Dr. Afonso Ligório e do Pr. Emílson dos Reis, pela confiança e suporte. Considero uma honra fazer parte dessa instituição. 


\section{Resumo}

Ao lidar com uma parte considerável da Bíblia Hebraica, o leitor precisa estar a par do que é Poesia Hebraica Bíblica, suas características, peculiaridades e nuances a fim de entender e apreciar o texto. Mas como os Hebreus não deixaram nenhum manual de poética, o debate sobre a poesia da Bíblia Hebraica envolve desde sua presença no texto até suas características gerais e específicas. No presente trabalho, apresenta-se uma breve discussão sobre a Poesia Hebraica Bíblica no cenário acadêmico atual. Também são expostas as características dessa poesia, com ênfase no paralelismo.

Palavras-chave: Bíblia Hebraica, Poesia Hebraica Bíblica, Paralelismo.

\section{Abstract}

When dealing with most part of the Hebrew Bible, the reader must be aware of what is biblical Hebrew poetry, its characteristics, peculiarities and details in order to understand and appreciate the text. Since there isn't a Hebrew manual of poetics, the debate about the biblical Hebrew poetry comprises from its presence in the text to its general and specific characteristics. The following research presents a brief discussion about Hebrew Bible in the current academic scenario, as the characteristics of this kind of poetry with an emphasis in parallelism.

Keywords: Hebrew Bible, Biblical Hebrew Poetry, Parallelism. 


\section{SUMÁRIO}

INTRODUÇÃO

\section{CAPÍtulo 1}

Poesia Hebraica Bíblica?

1.1 Características da Poesia Hebraica Bíblica

\section{CAPítulo 2}

O “GÊNIO” da Poesia Hebraica Bíblica 26

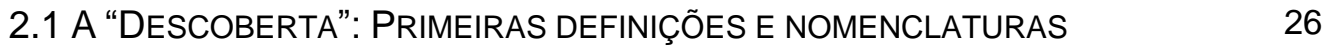

2.2 A REAFIRMAÇÃO: QUESTIONAMENTO DAS DEFINIÇÕES E NOMENCLATURAS

2.2.1 MICHAEL O'CONNOR: INOVAÇÃO NOMENCLATÓRIA E NOVA PROPOSTA DESCRITIVA

2.2.2 JAMES KUGEL: A CRÍTICA DAS DEFINIÇÕES 43

2.2.3 WILFRED WATSON: MANUAL DE ESTILO E TIPOLOGIA EXTENSIVA 47

2.2.4 MeIR WeISS E ROBERT Alter: A BUSCA POR SIMPLICIDADE 60

2.2.5 ADELE BERLIN: UMA APROXIMAÇÃO LINGUÍSTICA 62

2.2.6 CONSIDERAÇÕES POSTERIORES: REAFIRMAÇÕES 70

\section{Capítulo 3}

$\begin{array}{ll}\text { PRODUTOS DO PARALELISMO E UM PRINCÍPIO GERAL } & 77\end{array}$

$\begin{array}{ll}\text { 3.1 QUIASMO } & 77\end{array}$

$\begin{array}{ll}3.2 \text { MÉTRICA } & 90\end{array}$

$\begin{array}{ll}\text { 3.2.1 QUANTITATIVO } & 91\end{array}$

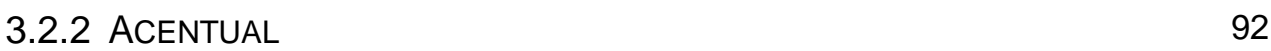

$\begin{array}{ll}3.2 .3 \text { SILÁBICO } & 94\end{array}$

3.2.4 SINTÁTICO $\quad 95$

3.2.5 NÃO HÁ MÉTRICA, HÁ PARALELISMO 96

$\begin{array}{ll}\text { 3.3 PaRES DE PALAVRAS } & 98\end{array}$

$\begin{array}{ll}3.4 \text { METÁFORA } & 103\end{array}$

$\begin{array}{ll}\text { 3.5 PRINCÍPIO GERAL: TENSÃO } & 107\end{array}$

\section{Capítulo 4}

Elementos PoÉticos Diversos 
$\begin{array}{ll}\text { 4.1 LINHA, BICÓLON E ESTROFE } & 109\end{array}$

4.2 ACRÓstico 111

4.3 REFRÃO 111

4.4 INCLUSÃO

$\begin{array}{ll}\text { 4.5 ELIPSE } & 113\end{array}$

4.5.1 ELIPSE RÍTMICA 114

4.6 AliteraÇÃo 115

$\begin{array}{ll}\text { 4.7 ASSONÂNCIA } & 116\end{array}$

$\begin{array}{ll}4.8 \text { RIMA } & 116\end{array}$

$\begin{array}{ll}4.9 \text { ONOMATOPEIA } & 117\end{array}$

$\begin{array}{ll}\text { 4.10 JOGO DE PALAVRAS } & 118\end{array}$

4.11 METONÍMIA 119

4.12 SINÉDOQUE 119

$\begin{array}{ll}\text { 4.13 MERISMA } & 120\end{array}$

4.14 PeRSONIFICAÇÃo OU ProsopopeIA 121

$\begin{array}{ll}\text { 4.15 ANTROPOMORFISMO } & 121\end{array}$

4.16 OXIMORO 122

$\begin{array}{ll}\text { 4.17 ANÁFORA } & 123\end{array}$

$\begin{array}{ll}4.18 \text { HIPÉRBOLE } & 124\end{array}$

$\begin{array}{ll}\text { 4.19 EUFEMISMO } & 125\end{array}$

$\begin{array}{ll}\text { 4.20 SARCASMO E IRONIA } & 126\end{array}$

$\begin{array}{ll}\text { 4.21 PaLAVRAS-CHAVE } & 127\end{array}$

$\begin{array}{lr}\text { 4.22 MUDANÇA DE PESSOA } & 128\end{array}$

$\begin{array}{lr}\text { CONCLUSÃo } & 130\end{array}$

$\begin{array}{ll}\text { REFERÊNCIAS BIBLIOGRÁfICAS } & 133\end{array}$ 
"How something is said is not peripheral to what is said."

Franz Rosenzweig 


\section{INTRODUÇÃO}

Robert Alter, professor de Hebraico e Literatura Comparada na Universidade da Califórnia (Berkeley), em seu livro The Art of Biblical Poetry, afirma:

Poesia [...] não é apenas um conjunto de técnicas para dizer extraordinariamente o que poderia ser dito de outra. Antes, é uma maneira particular de imaginar o mundo - particular no duplo sentido em que poesia como tal tem sua própria lógica, seus próprios caminhos de fazer conexões e engendrar implicações, e porque cada sistema de poesia tem certas forças distintivas semânticas que seguem o impulso de suas disposições formais e hábitos de expressão. ${ }^{1}$ (Alter, 1985, p. 151)

Esse pequeno fragmento do discurso de Alter aponta para a realidade de que ao lidar com uma parte considerável da Bíblia Hebraica $(\mathrm{BH})$, o leitor precisa estar a par do que é Poesia Hebraica Bíblica (PHB), suas características, peculiaridades e nuances a fim de entender e apreciar o texto. Em outro de seus textos, Alter diz: "Qualquer interpretação crítica dos livros poéticos da Bíblia Hebraica é dependente, ou certamente deveria ser dependente, de um entendimento do caráter distintivo da poesia bíblica."2 (Alter, 1998, p. 226)

A necessidade de entender a PHB, entretanto, esbarra em alguns problemas. James Kugel, professor durante onze anos na Universidade de Harvard e, atualmente, professor da Universidade Bar-llan, em Israel, aponta para a ausência da própria palavra poesia em hebraico e para a ausência de uma poética hebraica. (Cf. Kugel, 1981, p. 69, 86, 127)

\footnotetext{
${ }^{1}$ No corpo do texto as citações aparecerão sempre em português, fruto da tradução do autor desse trabalho, mas serão apresentadas em sua língua de origem em notas de rodapé: "Poetry [...] is not just a set of techniques for saying impressively what could be said otherwise. Rather, it is a particular way of imagining the world - particular in the double sense that poetry as such has its own logic, its own ways of making connections and engendering implications, and because each system of poetry has certain distinctive semantic thrusts that follow the momentum of its formal dispositions and habits of expression."

2 "Any critical interpretation of the poetic books of the Hebrew Bible is dependent, or certainly should be dependent, on an understanding of the distinctive character of biblical poetry."
} 
A poética é exatamente "uma tentativa de especificar como a literatura funciona e como nos permite perceber os significados que percebemos". ${ }^{3}$ (Barton, 1996, p. 205) Assim, "ao contrário dos Gregos, os antigos Israelitas não nos deixaram nenhuma 'Poética', ou seja, nenhuma definição sistemática ou descrição do fenômeno". ${ }^{4}$ (Lichtenstein, 1984, p. 107)

Entretanto, apesar da ausência de uma poética hebraica, a busca por entender a PHB perpassa séculos, como comenta Adele Berlin, professora na Universidade de Maryland e ex-presidente da Society of Biblical Literature (SBL): "a definição do que constitui a poesia bíblica, a descrição das características poéticas e a identificação de passagens poéticas variaram grandemente ao longo dos séculos". ${ }^{5}$ (Berlin, 1996, p. 301) E como resultado dessa busca, "tem havido confusão considerável, ao longo dos anos, a respeito dos locais em que há poesia na Bíblia e dos princípios segundo os quais essa poesia funciona". (Alter, 1997, p. 653)

Parte da reflexão acima é o que motiva esse trabalho: como funciona a Poesia Hebraica Bíblica? Quais são suas características? Se, como diz Meir Weiss, professor emérito da Universidade Hebraica de Jerusalém, "o poético é manifesto na forma"6 ${ }^{6}$ (Weiss, 1984, p. 272), então é mais do que preciso entender a forma da PHB para usufruir de sua beleza e de sua mensagem. "Ler poesia Hebraica exige que o intérprete preste atenção tanto à natureza literária e estética do texto quanto ao alcance semântico de palavras individuais." ${ }^{7}$ (Tucker Jr, 2008, p. 585)

Para tanto, o presente trabalho será dividido em quatro partes. No primeiro capítulo apresentar-se-á um breve panorama do debate a respeito da Poesia Hebraica Bíblica entre os estudiosos mais recentes. No segundo capítulo, será exposto o desenvolvimento histórico da principal característica da PHB, o paralelismo. Depois, outras características decorrentes do paralelismo (quiasma, métrica, pares de palavras e metáfora) que, junto dele e por causa

\footnotetext{
3 "[...] an attempt to specify how literature 'works', how it enables us to perceive the meanings we do perceive [...]."

4 "Unlike the Greeks, the ancient Israelites have left us no 'Poetics', that is, no systematic definition or description of the phenomenon."

5 "[...] the definition of what constitutes biblical poetry, the description of poetic features, and the identification of poetic passages have varied greatly over the centuries."

6 "The 'poetic' is manifest in the form [...]."

7 "Reading Hebrew poetry demands that the interpreter pay as much attention to the literary and aesthetic nature of the text as to the semantic range of individual words."
} 
dele, são elementos constantes dentro da PHB. Ainda no terceiro capítulo, será tratado um princípio geral que rege a poesia bíblica. E, por fim, no quarto e último capítulo, será abordada uma série de características poéticas que, de certa maneira, são secundárias e se organizam a partir das outras, trabalhadas no segundo e terceiro capítulos. Após esse corpus, o trabalho será concluído com as reflexões resultantes de todo o processo.

O presente trabalho não visa ser um manual exaustivo e nem abarcar toda a discussão sobre cada nuance formadora PHB. O objetivo é prover, em língua portuguesa, uma introdução que dê conta de um panorama geral, com boa quantidade de exemplos de textos bíblicos. 


\section{Capítulo 1}

\section{Poesia Hebraica Bíblica?}

"Não há palavra para 'poesia' em hebraico bíblico". ${ }^{8}$ (Kugel, 1981, p. 69) Com esta afirmação, James Kugel procura argumentar sobre a inexistência da ideia de Poesia ${ }^{9}$ Hebraica Bíblica (PHB). Embora, em primeira instância, esta pareça uma ideia polêmica, levanta uma questão importante: existe, realmente, PHB?

Kugel alega que não, acrescentando: "Então, falar de 'poesia' na Bíblia será, em alguma medida, impor um conceito estrangeiro ao mundo bíblico". ${ }^{10}$ (Ibid., p. 69) Ele entende que a ideia de "poesia" é uma tentativa de imputar conceitos clássicos, como métrica, rima, etc., ao texto bíblico (Cf. lbid., p. 300$301)$ e rejeita por completo a terminologia "poesia", afirmando: "[...] poesia em hebraico antigo, simplesmente não existe". ${ }^{11}$ (lbid., p. 86)

Há uma ênfase insistente de Kugel na acusação de 'empréstimo' de teorias literárias externas ao texto. Em certo ponto ele diz: "Ao longo dos anos, métrica, rima e outras armadilhas da poesia têm sido 'descobertas' na Bíblia, sempre definidas de acordo com as tradições correntes na língua do próprio escritor". ${ }^{12}$ (Ibid., p. 301) Sem a mesma ênfase e discordando da premissa fundamental de Kugel - a de que não existe PHB - Adele Berlin sustenta: "[...] eruditos em cada época e lugar, [...] aplicaram ao texto bíblico definições de poesia de suas próprias tradições literárias. [...] Nós fazemos o mesmo hoje $[\ldots]^{13}{ }^{13}$ (Berlin, 1996, p. 301)

\footnotetext{
8 "There is no word for 'poetry' in biblical Hebrew". Todas as traduções para o português foram feitas pelo autor do trabalho, mas serão apresentadas, também, em suas versões de origem em notas de rodapé.

${ }^{9}$ Wendland acredita que o termo "poesia" acaba causando confusão, por já vir carregado de aspectos formais (cf. Wendland, 1994, p. 3), mas não apresenta alternativa.

10 "Thus, to speak of 'poetry' at all in the Bible will be in some measure to impose a concept foreign to the biblical world."

11 "[...] poetry in ancient Hebrew simply does not exist."

12 "Over the years, meter, rhyme, and other trappings of poetry have all been 'discovered' in the Bible, ever defined according to traditions current in the writer's own tongue." O uso das aspas na palavra "discovered" (descobertas) denota um certo tom de ironia.

${ }_{13}$ "[...] scholars in each time and place, [...] have applied to the biblical text definitions of poetry from their own literary tradition. [...] We do the same [...]."
} 
Entretanto, Meir Weiss, apresentando seu método de Interpretação Total, ainda que reconheça que "o comentarista é sempre prisioneiro do seu próprio tempo"14 (Weiss, 1984, p. 19), ressalta que: "A verdadeira interpretação é o resultado da ocasião afortunada quando o intérprete não subjuga a criação, mas é subjugado por ela". ${ }^{15}$ (Ibid.)

A relação entre o que é poesia hebraica bíblica e o conceito literário de poesia em diversas épocas e lugares é inevitável, mas não deve subjugar o texto bíblico. Essas teorias poéticas externas devem ser aplicadas de maneira cautelosa (cf. Petersen e Richards, 1992, p. 3), mas é o poema que deve falar. (Cf. Weiss, 1984, p. 63)

Outra dificuldade apresentada para o estudo da PHB é que os poemas não estão dispostos no texto como poesia, ou seja, em versos. (Cf. Alter, 1985, p. 5) Essa dificuldade introduz duas questões relevantes: o que é poesia? E qual é a diferença entre poesia e prosa?

Kugel, apesar de afirmar não existir PHB, parece definir o que ela seria dizendo: "Em suma, o que é chamado de 'poesia' bíblica é um complexo de efeitos elevados usados com combinações e intensidades que variam amplamente [...]". ${ }^{16}$ (Kugel, 1981, p. 94) Além disso, diferencia prosa de poesia afirmando: "'Prosa' e 'poesia' são uma questão de nívell. ${ }^{17}$ (Ibid., p. 302) Essa postulação, inclusive, lembra a mesma feita por Freedman: "[...] a distinção é, frequentemente, quantitativa ao invés de qualitativa e em termos de nível ao invés de tipo [...." ${ }^{18}$ (Freedman, 1980, p. 2)

Para Cloete, a confusão surge pelo uso dos termos "poesia" e "prosa" como se fossem opostos, o que, segundo ele, não são. Ele afirma que o oposto da prosa é o verso, pois ambos se referem a forma. Poesia, ainda segundo ele, se refere a qualidade. (Cf. Cloete, 1989, p. 2) O'Connor assevera: "A diferença

\footnotetext{
14 "[...] the commentator is always a prisoner of his own times."

15 "The true interpretation is the outcome of that fortunate occasion when the interpreter does not subjugate the creation but is subjugated by it."

16 "In sum, what is called biblical 'poetry' is a complex of heightening effects used in combinations and intensities that vary widely [...]."

17 "'Prose' and 'poetry' are a matter of degree."

18 "[...] the distinction is often quantitative rather than qualitative, and in terms of degree rather than kind [...]."
} 
entre prosa e verso, apesar de ser, provavelmente, universal, é impossível de ser descrita de qualquer modo simples". ${ }^{19}$ (O'Connor, 1980, p. 66)

Laferrière aponta um possível problema que pode ter interferido na maneira como se 'procura' a poesia na Bíblia Hebraica: "Poeticistas têm simplesmente crescido acostumados a 'olhar para' o poema, como se realmente ele fosse aquele objeto que o poeta escreve em um plano". ${ }^{20}$ (Laferrière, 1978, p. 16) Marjo Korpel e Johannes de Moor indicam justamente o costume da "interpretação linear" como um dos motivos da dificuldade do "leitor moderno" em 'achar' a PHB. (Cf. Korpel e de Moor, 1988, p. 60)

O que ocorre é que a linha divisória entre poesia e prosa é tênue e, muitas vezes, confusa. (Cf. Roberts, 2001, p. 53) O próprio Kugel sugere que a distinção é melhor entendida como dois pontos em uma linha contínua (Kugel, 1981, p. 85), no que Petersen e Richards concordam:

Os poetas hebreus não nos contam que escreveram um poema. Eles escreveram em verso e é nossa tarefa como ambos, leitores e intérpretes, determinar se um texto é um poema e como essa determinação ajudará nossa leitura. ${ }^{21}$ (Petersen e Richards, 1992, p. 13)

Ernst Wendland coloca essa ideia de "poesia-prosa continuum" (Ibid.) de maneira visual (cf. Wendland, 1994, p. 3):

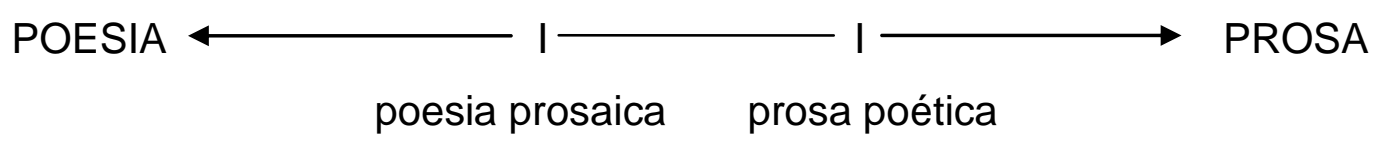

Segundo Weiss, a natureza da poesia estaria além da linguagem representacional (característica da prosa): "A natureza da poesia é que ela não

\footnotetext{
19 "The difference between prose and verse, though it is probably universal, is impossible to describe in any simple way."

20 "Poeticists have simply grown accustomed to 'looking at' the poem, as if it really were that object which the poet writes down in a plane."

21 "The Hebrew poets do not tell us that they have written a poem. They write in verse and it is our task, as both readers and interpreters, to determine whether a text is a poem and how that determination assists our reading."
} 
apenas representa o mundo real, como o reflete, no espelho dos sentidos internos e externos; sua linguagem sozinha é o que toca a mente e as emoções". ${ }^{22}$ (Weiss, 1984, p. 241)

Sobre essa relação entre prosa e poesia, Robert Alter escreve:

De fato, é raro encontrar em algum lugar um estilo poético que não guarde alguma relação com a prosa literária da mesma cultura; em vez disso, o que acaba por ocorrer em muitas instâncias é que a prosa literária é influenciada pela poesia contemporânea, ou anterior, na mesma língua, quase sempre buscando conscientemente ou inconscientemente atingir para si mesma um status quase poético sem as restrições formais limitantes do verso. ${ }^{23}$ (Alter, 1985, p. 6-7)

Assim, a diferenciação primária entre a prosa e a poesia bíblica não se daria pela versificação, mas pela presença mais acentuada de certos elementos literários/poéticos (cf. Berlin, 1985, p. 9-10) e pela densidade compacta do seu discurso. (Cf. Fokkelman, 2001, p. 15)

Ou seja, não é somente a mensagem, mas a maneira/forma como ela é transmitida. Berlin assevera: "Um poema exprime pensamento, e, além disso, exprime que o pensamento, de maneira consciente de si, através de uma estrutura especial de linguagem, chama a atenção para o 'como' da mensagem e também para o 'o quê'."24 (Berlin, 1996, p. 302)

A PHB é, então, um conjunto de elementos literários concentrados, estruturados de determinada maneira, para transmitir uma mensagem em um determinado formato. Buber enfatiza essa ideia de relacionamento entre forma e conteúdo: "[...] é impossível transmitir o conteúdo sem ao mesmo tempo estar transmitindo a forma. Como alguma coisa é dita não é periférico ao o quê é

\footnotetext{
22 "The nature of poetry is that it does not so much represent the real world as reflect it, in the mirror of internal and external senses; its language alone is what touches the mind and emotions."

23 "In fact, it is rare to find anywhere a poetic style that does not bear some relation to the literary prose of the same culture; or rather, it turns out in many instances that literary prose is influenced by contemporary or antecedent poetry in the same language, often seeking knowingly or unwittingly to achieve for itself a quasi-poetic status without the formal constraints of verse."

24 "A poem conveys thought, and, moreover, it conveys that thought in a self-conscious manner, through a special structuring of language that calls attention to the 'how' of the message as well as to the 'what'."
} 


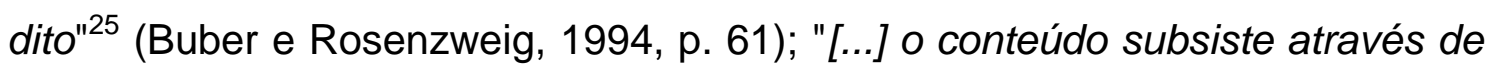
sua própria inseparável forma [...]". ${ }^{26}$ (Ibid., p. 28)

Deste modo, não somente entende-se que há PHB, mas também que ela possui elementos comuns à prosa bíblica, usados de maneira mais intensiva, e que sua forma poética carrega relação intrínseca com sua mensagem, como Buber coloca: "Poesia... comunica a nós uma verdade que não poderia vir em palavras de nenhuma outra maneira a não ser justamente essa, na maneira de sua forma". ${ }^{27}$ (Buber apud Weiss, 1984, p.35)

Retornando, então, à frase de abertura deste capítulo, sobre a não existência do termo "poesia" em Hebraico e que é um dos argumentos de Kugel contra a ideia de $\mathrm{PHB},{ }^{28}$ é preciso notar que diversos outros termos hebraicos são utilizados para se referir a porções que, desde antigamente, são reconhecidas como poéticas. (Cf. Berlin, 1996, p. 301)

Termos específicos, como שִ̣ (šîr), ${ }^{29}$ que significa 'cântico', 'canção' (Cf. Koehler e Baumgartner, 2001, p. 1481) e aparece em diversos contextos sozinha (Jz 5:12; SI 65:1; etc) e em outros carregando uma espécie de

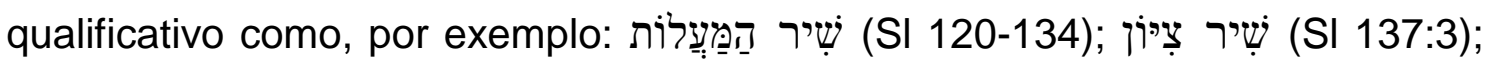
(SI שִיר חָדָדש (SI 96:1, 98:1, 149:1); os quais indicariam gêneros poéticos. (Cf. Schökel, 2000, p. 8; Berlin, 1996, p. 301; Meir, 2004, 98-107)

Outro desses termos, מִמְזמוֹר, que significa 'salmo' (cf. Koehler e Baumgartner, 2001, p. 566), aparece em cerca de 57 salmos e, às vezes, combinado com שִיר. (SI 67:1; 68:1; etc.) Koehler e Baumgartner apresentam uma discussão breve sobre a ocorrência das duas palavras, שִזְמוֹר e שִׁיר, usadas de maneira bem próxima, mas que podem guardar certa diferença, sendo a primeira referência utilizada para a cantilação do texto sem

\footnotetext{
25 "[...] it is impossible to transmit the content without at the same time transmitting the form. How something is said is not peripheral to what is said."

26 "[...] the content subsists throughout in its own inseparable form [...]"

27 "Poetry... imparts to us a truth which cannot come to words in any other manner than just in this one, in the manner of this form."

${ }^{28}$ Berlin aponta a não existência do termo "narrativa" ou "estória" em hebraico e parece sugerir, ironicamente, que nem por isso se deva sugerir sua inexistência. (Cf. Berlin, 1983, p. 11)

${ }^{29}$ Todas as transliterações contidas no trabalho seguirão o padrão acadêmico adotado pela Society of Biblical Literature (SBL), exposto no SBL Handbook of Style. (Alexander et al, 1999, p. 25-27)
} 
instrumentos musicais e a segunda para cantilação com os mesmos. (Cf. Koehler e Baumgartner, 2001, 1481-1482)

Mais um termo é קִינָה, que significa 'lamento', 'canção de funeral' (cf. Ibid., p. 1097-1098) e aparece com uso individual (2 Cr 35:25) e coletivo. (Jr 9:9) Além desses, מָׁiָ, que significa 'provérbio', 'ditado', etc. (cf. Koehler e Baumgartner, 2001, p. 647-648) é bem frequente e aparece como título do livro de Provérbios (Pv 1:1) e ainda na introdução dos dizeres de Balaão. ( $N m$ 23:7, $18 ; 24: 3,15)$

Schökel ainda apresenta mais alguns termos (cf. Schökel, 2000, p. 8-9) e tanto ele quanto Berlin reforçam que a terminologia da própria Bíblia Hebraica $(\mathrm{BH})$ aponta porções que devem ser analisadas e reconhecidas como poéticas. (Cf. Schökel, 2000, p. 9-10; Berlin, 1996, p. 301)

Um exemplo do uso do termo שִׁיר (šîr), como marcação de um espaço diferente de uma narrativa comum, é o texto de Juízes 5. Esse texto, inclusive, é analisado por três autores - Robert Alter, ${ }^{30}$ Adele Berlin $^{31}$ e Alviero Niccacci ${ }^{32}$ - para evidenciar a diferença entre prosa e poesia, bem como demonstrar a presença de elementos característicos da PHB.

Robert Alter realça a relevância da análise da Canção de Déborah (Jz 5) dizendo:

A Canção de Déborah é muito longa para ser analisada aqui em sua totalidade, mas a notável conclusão da seção (Jz 5:2431 ), a qual reconta a morte do general canaanita Sisera pelas mãos determinadas de Jael é, em si mesma, uma instância iluminada das possibilidades artísticas da narrativa versificada em Hebraico, e é mais do que isso, instrutiva porque pela maneira como molda seu material dificilmente pode ser comparada com a versão em prosa do mesmo evento que precede a Canção. ${ }^{33}$ (Alter, 1985, p. 43)

\footnotetext{
${ }^{30}$ Cf.Alter, 1985, p. 43-50.

${ }^{31}$ Cf. Berlin, 1985, p. 12-15.

32 Cf. Niccacci, 1997, p. 77-80.

33 "The Song of Deborah is too long to be analyzed here in its entirety, but the remarkable concluding section (Judg. 5:24-31), which recounts the Canaanite general Sisera's death at the unflinching hands of Jael, is in itself an illuminating instance of the artistic possibilities of Hebrew verse narrative, and is all the more instructive because the way it shapes its materials can be hardly compared with the prose version of the same events that precedes the Song."
} 
Comparando diretamente os trechos semelhantes das duas versões do mesmo relato, Juízes 4:17-24 e Juízes 5:24-31, ${ }^{34}$ a diferença entre o que seria prosa e poesia no texto bíblico parece ficar evidente, ainda que os dois textos sirvam a propósitos diferentes: Jz 4 conta/informa da batalha e de seu desfecho e Jz 5 celebra/canta a vitória. (Cf. Niccacci, 1997, p. 78)

Em Juízes 4:19 lemos: ${ }^{35}$

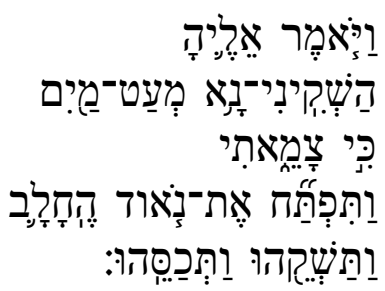

E disse a ela:

dá-me de beber, por favor, um pouco de água

pois estou sedento

e ela abriu um odre de leite

e deu a ele de beber e o cobriu. ${ }^{36}$

Já em Juízes 5:25 temos: ${ }^{37}$

Água ele pediu

leite ela deu

em tigela nobre

ela trouxe nata.

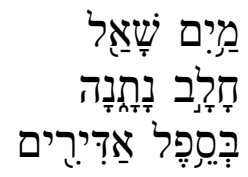

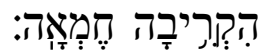

Nos dois trechos, que contam o mesmo segmento da história, é possível notar paralelismo. Em Jz 4:19 a mesma raiz שקה é repetida e os termos

\footnotetext{
${ }^{34}$ Uma outra análise comparativa é a de Ogden, 1994, p. 111-130.

${ }^{35}$ A divisão do verso segue a sugestão de Niccacci, que também "versifica" o relato prosaico para acentuar a diferença, não pela forma, mas pelas características de ambos (cf. Niccacci, 1997, p. 78), ao contrário de Berlin, que mantém o texto em prosa no formato linear e coloca o texto poético em versos. (Cf. Berlin, 1985, p. 12)

${ }^{36}$ As traduções do hebraico para o português, salvo indicação contrária, são do autor desse trabalho. As traduções da $\mathrm{BH}$ fornecidas pelos autores citados serão apresentadas nas notas de rodapé. Dicionários, léxicos e Bíblias consultadas estão na bibliografia do trabalho. Cf. Brown, Driver, Briggs, 1886; Clines (ed.), 2009; Dotan (ed.), 2001; Ellieger e Rudolph (eds.), 1997; Koehler e Baumgartner, 2001; Owens, 1989; Schökel, 1997.

${ }^{37}$ A divisão em versos aqui também segue sugestão de Niccacci. (1997, p. 79)
} 
semanticamente correlatos, 'leite' e 'água', também se posicionam como complementos diretos do verbo. Já em Jz 5:25 o paralelismo, mais estrutural, enfatiza o contraste entre o que 'ele', Sisera, pede - água - e o que 'ela', Jael, Ihe dá - leite. (Cf. Berlin, 1985, p. 12)

Também relevante é que no relato em prosa há uma linearidade em narrar o evento, ao passo que no relato poético há uma segmentação na comunicação. Enquanto em Jz 4:19 há um verbo para o pedido de Sisera e um verbo para a resposta de Jael, em Jz 5:25 também há um verbo para o pedido, mas dois para a resposta. Além disso, no primeiro texto há o paralelo 'água' e 'leite' que, embora também apareça no segundo, ocorre com um acréscimo - a nata. (Cf. Niccacci, 1997, p. 79)

Comparando esses dois textos, Alter aponta que em Jz 5:25 (e no restante do trecho poético) há uma intensificação derivada de um certo incremento na exposição da história, ausente em Jz 4:19 - a nata e a tigela nobre/real, por exemplo. (Cf. Alter, 1985, p. 44)

Já Berlin verifica características definitivas da PHB, entre as quais, a concisão. Essa concisão é facilitada pela frequente omissão do artigo definido, do indicador do objeto direto e do pronome relativo - אשר e את e respectivamente. (Cf. Berlin, 1996, 303)

A omissão dessas partículas é de tal relevância que David Noel Freedman chega a definir a PHB baseado na ocorrência ou não delas. Daí serem chamadas de 'partículas de prosa'. Esse critério "mecânico" e mensurável através de fórmulas e tabulações, não somente separaria a poesia da prosa de maneira efetiva e simples, como também apontaria a frequência em que ocorre a PHB na BH. (Freedman, 1980, p.2-3; Freedman, 1987, p. 1218) Andersen e Forbes, com ajuda de mecanismos computadorizados documentam a ocorrência ou não dessas 'partículas de prosa'. (1983, p. 165183)

Voltando a Berlin, além da concisão, ela conclui que "a poesia usa o paralelismo como seu mecanismo constitutivo ou construtivo, enquanto a não- 
poesia, embora contenha paralelismo, não estrutura sua mensagem sobre um sistemático uso do paralelismo". ${ }^{38}$ (Berlin, 1985, p. 16)

Roman Jakobson, falando exatamente sobre o uso sistemático do paralelismo na poesia (no caso, poesia russa), diferencia poesia de prosa na base de suas etimologias:

Nós temos aprendido a sugestiva etimologia dos termos prosa e verso - o primeiro, [...] 'discurso tornado direto', e o último, [...] 'retorno'. Portanto, nós precisamos consistentemente concluir de todas inferências o fato óbvio de que em cada nível de linguagem, a essência do artifício poético consiste em um recorrente retorno. ${ }^{39}$ (Jakobson, 1966, p. 399)

Niccacci ressalta que a comunicação poética é mais segmentada e que os paralelos de informação são similares entre as linhas, mas mais desiguais na prosa. Isso se dá porque a "poesia se desenvolve por segmentos de informação dispostos em linhas paralelas ao invés de peças coordenadas de informação ligadas por uma sequência linear." ${ }^{40}$ (Niccacci, 2006, p. 266) Além de mencionar que em prosa o sistema verbal é detectável, enquanto na poesia seria indetectável, embora deva-se evitar a tendência de ignorar seu modo verbal. (Cf. Niccacci, 1997, p. 77-78; Niccacci, 2006, p. 247-26841; Tatu, 2008, p. $\left.8^{42}\right)$

Uma marca da PHB destacada por Robert Alter é sua intensidade, o que ele denomina de "estrutura de intensificação". Essa intensificação seria o uso de paralelismo para criar progressão e até mesmo pressão no texto. (Cf. Alter, 1985, p. 61) Schökel, de maneira similar, afirma: "Nós devemos falar ao invés

\footnotetext{
38 "Poetry uses parallelism as its constitutive or constructive device, while nonpoetry, though it contains parallelism, does not structure its message on a systematic use of parallelism."

39 "We have learned the suggestive etymology of the terms prose and verse - the former, [...] 'speech turned straightforward', and the latter, [...] 'return'. Hence, we must consistently draw all inferences from the obvious fact that on every level of language, the essence of poetic artifice consists in recurrent returns."

40 "[...] poetry develops by segments of information disposed in parallel lines rather than by coordinate pieces of information linked in a linear sequence."

${ }^{41}$ Nesse artigo, Alviero Niccacci desenvolve o que seria uma teoria verbal para a prosa e a poesia bíblica, embora sua ênfase seja somente o sistema verbal poético, para o qual ele lista uma série de exemplos.

${ }^{42}$ Tatu fala da flexibilidade no uso dos modos verbais na PHB em relação à narrativa bíblica. Jero também menciona essa flexibilidade, mas argumenta que o sistema verbal não é, de modo nenhum, algo a ser descartado. (Cf. Jero, 2008, p. 184)
} 
de frequência, predominância, densidade, intensidade". ${ }^{43}$ (Schökel, 2000, p. 19) Além de Alter e Schökel, Fokkelman também entende a densidade como característica fundamental da poesia, vista por ele como o discurso mais compacto e concentrado possível. (Cf. Fokkelman, 2001, p. 15)

A abordagem de Silviu Tatu é singular. Ele menciona que a prosa e poesia seriam gêneros distintos responsáveis por causar sensações e efeitos específicos na audiência. Em nível estético, a poesia estaria associada à subjetividade, a expressões vívidas e atemporalidade, enquanto a prosa seria o completo oposto, embora reconheça que essa distinção, em termos de oposição, seja tarefa difícil e complexa. (Cf. Tatu, 2008, p. 1)

Das perguntas levantadas (existe algo que pode ser chamado Poesia Hebraica Bíblica?; qual a diferença entre poesia e prosa?; o que é poesia bíblica?), David Petersen e Kent Richards resumem a linha adotada por este trabalho quando concluem:

Como resultado, nós rejeitamos a noção de que não haja poesia na Bíblia Hebraica. Essa opinião não pretende negar que a prosa e a literatura poética Hebraica compartilhem características importantes. Mesmo assim, a distinção entre poesia e prosa não é uma imposição de categorias estrangeiras gregas ao Hebraico. Em vez disso, em Hebraico, como em muitas outras línguas, há um corpo literário que pode razoavelmente ser identificada como poesia. ${ }^{44}$ (Petersen e Richards, 1992, p. 14)

\subsection{Características da Poesia Hebraica Bíblica}

Lichtenstein pondera sobre o funcionamento da PHB dizendo:

No melhor de qualquer tradição poética, a técnica poética não é um conjunto de regras a serem seguidas por si mesmas, mas uma reflexão verdadeira dos valores estéticos partilhados [...].

\footnotetext{
43 "We must speak rather of frequency, predominance, density, intensity."

44 "As a result, we reject the notion that there is no poetry in the Hebrew Bible. This judgment is not intended to deny that Hebrew prose and poetic literature share important features. Nonetheless, the distinction between poetry and prose is not an imposition of foreign Greek categories on Hebrew. Rather, in Hebrew as with many other languages there is a body of literature that may reasonably be identified as poetry."
} 
Assim, em poesia bíblica, observamos várias técnicas formais de composição, todas contribuindo para a conquista de um idealmente concebido e abarcante senso de balanço. ${ }^{45}$ (Lichtenstein, 1984, p. 114-115)

Assim, diversos autores elaboraram listas sobre os principais elementos da PHB. E ainda que esses elementos sejam comuns também à prosa, são utilizados de maneira mais intensiva nos trechos poéticos. (Cf. Salisbury, 2004, p. 3)

$\mathrm{Na}$ verdade, como coloca Meir Sternberg, as convenções da poesia bíblica e da prosa vão divergir no uso desses elementos. Sternberg assinala que na PHB, por exemplo, as estruturas equivalentes (paralelismo) preservam o núcleo do significado, mas não das palavras, enquanto na prosa a flexibilidade é maior. (Cf. Sternberg, 1987, p. 386)

George B. Gray, já há muito, reconhece que há uma grande diferença de opiniões sobre quais seriam as características da PHB, mas estabelece o paralelismo e a métrica como as duas mais importantes configurações da poesia bíblica. (Cf. Gray, 1915, p. 3-4)

Inclusive, sobre essa diferença de opiniões levantada previamente por Gray, Robert Alter escreve:

Quais são os elementos formais que fazem um poema na Bíblia Hebraica? A ingenuidade incorrigível do senso comum pode levar alguém a supor que os rudimentos de uma resposta são evidentes, mas, de fato, não há nenhum aspecto da literatura bíblica que trouxe mais contraditórias, intricadas e, algumas vezes, fantásticas visões, desde a antiguidade até as mais recentes publicações. ${ }^{46}$ (Alter, 1985, p. 3)

\footnotetext{
45 "In the best of any traditional poetry, poetic technique is not some arbitrary set of rules to be followed for their own sake, but a true reflection of shared aesthetic values [...]. Just so in biblical poetry, we observe various formal techniques of composition, all contributing to the attainment of an ideally perceived, all-embracing, sense of balance."

46 "What are the formal elements that make up a poem in the Hebrew Bible? The incorrigible naïveté of common sense might lead one to suppose that the rudiments of an answer would be self-evident, but in fact there is no aspect of biblical literature that has elicited more contradictory, convoluted, and at times quite fantastical views, from late antiquity to the last scholarly publications."
} 
Wilfred Watson apresenta uma relação de dezenove características da PHB: presença de formas lineares estabelecidas; elipse (especialmente de verbos); vocabulário não usual; concisão; ordem de palavras não usual; arcaísmos; métrica e rima; regularidade e simetria; paralelismo; pares de palavras; padrões quiásticos; incluso; quebra de frases estereotipadas; repetição; paralelismo de gênero; tricólon; rima; padrões sonoros; e ausência (ou uso raro) de elementos prosaicos. (Cf. Watson, 1984, p. 46-47)

Para Meir Weiss, a expressão poética é manifesta através do tamanho da sentença, da escolha das palavras e de sua ordem, e na estrutura de relacionamento entre as partes e o todo. Portanto, o efeito da linguagem poética seria atingido através da sintaxe. (Cf. Weiss, 1984, p. 241)

Adele Berlin lembra que como a BH não define ou descreve sua própria poesia, cada estudioso acabará definindo-a de acordo com sua visão, dificultando o consenso. Ainda assim, Berlin acredita que existe um consenso em torno da seguinte definição: "Poesia bíblica é um tipo de discurso elevado, composto de linhas concisas, e que emprega um alto grau de paralelismo e imagens." ${ }^{47}$ (Berlin, 2004, p. 2098)

Walter Cloete lista cinco qualidades distintivas da PHB: 1) uso especial de sons; 2) preferência por palavras e combinações entre elas, diferentes do discurso normal; 3) extensivo uso de metáforas e figuras de linguagem; 4) estrutura rítmica do texto; e 5) elementos sintáticos não usuais. (Cf. Cloete, 1989, p. 4)

Ernst Wendland lista dez características formais que, devido à sua aparição frequente, são representativas da $\mathrm{PHB}^{48}$ : balanço entre as linhas causado por paralelismo; repetição generalizada - também decorrência do paralelismo; linguagem compacta; uso reduzido das partículas de prosa; arranjos sintáticos não usuais (quiasmos, anacruses, etc.); jogo fonológico (aliteração, assonância, rima, onomatopeia, etc.); linguagem figurativa e imagística; recursos afetivos/emocionais (ironia, hipérbole, alusão); discurso

\footnotetext{
47 "Biblical poetry is a type of elevated discourse, composed of terse lines, and employing a high degree of parallelism and imagery."

${ }^{48}$ Kathryn J. Partridge menciona essa lista como a "melhor lista" de características da PHB do ponto de vista linguístico, apesar de apresentá-la em ordem distinta da de Wendland. (Cf. Partridge, 1995, p. 12-13)
} 
direto e formas poéticas tradicionais (pares de palavras, fórmulas introdutórias e conclusivas, clichês e motivos da própria BH). Esses dez itens seriam um guia indicativo de aproximação do texto poético. (Cf. Wendland, 1994, p. 3-5)

Mas, apesar de tão diversas e variadas listas, algumas características parecem se repetir em cada uma e o paralelismo é uma delas. Alan Cooper, em um excurso breve no livro de Weiss, atesta:

Paralelismo, criado por modelos de equivalência linguística projetada em sequências de sons, acentos, palavras, sentenças, textos e assim por diante, é a característica dominante da linguagem poética. ${ }^{49}$ (Weiss, 1984, p. 406)

Benjamin Hrushovski também aponta o papel básico do paralelismo dizendo:

Poesia bíblica, e talvez literatura bíblica como um todo, provê um sistema mais flexível das formas de expressão. O princípio básico é o paralelismo. Uma unidade poética consiste de dois ou três versos (ou cólons) exibindo características de equivalência em seu formato rítmico, sua sintaxe e sua semântica assim como em seus muitos elementos concomitantes, como o número de sílabas em palavras paralelas, repetições sonoras e morfologia. ${ }^{50}$ (Hrushovski, 1981, p. 58)

D. Phillip Roberts afirma: "[...] paralelismo é o verdadeiro gênio da poesia hebraica. Ele e seu derivado, o bicólon, são os mais importantes elementos característicos da poesia hebraica." ${ }^{51}$ (Roberts, 2001, p. 54)

Assim, no capítulo seguinte, apresentaremos o 'verdadeiro gênio' da PHB, o paralelismo, e o que dele decorre.

\footnotetext{
49 "Parallelism, created by patterns of linguistic equivalence projected into sequences of sounds, accents, words, sentences, texts, and so forth, is the dominant characteristic of poetic language."

50 "Biblical poetry, and perhaps biblical literature as a whole, provides a most flexible system of expressive forms. The basic principle is parallelism. A poetic unit consists of two or three versets (or 'cola') displaying traits of equivalence in their rhythmical make-up, their syntax, and their semantics, as well as in many concomitant features, such as the number of syllables in parallel words, sound-repetition, and morphology."

51 "[...] parallelism is the true genius of Hebrew poetry. It and its corollary, the bicolon, are the most characteristic features of Hebrew poetry."
} 


\section{O "Gênio" da Poesia Hebraica Bíblica}

"O estudo moderno de poesia bíblica começa com exatidão em 1753 com a publicação do seminal De sacra poesi Hebraeorum, de Robert Lowth." ${ }^{52}$ (Harris, 2004, p. 1) Nesse trabalho, o bispo de Londres e professor de Poesia em Oxford (cf. O'Connor, 1997, p. 638), Robert Lowth, introduz o conceito de parallelismus membrorum, que seria a estruturação de um verso em duas partes paralelas, ou equivalentes. (Cf. Cloete, 1989, p. 21)

\subsection{A "Descoberta": Primeiras definições e nOMenclaturas}

O raciocínio de Lowth sobre o paralelismo é construído a partir da ideia de "conformação" entre sentenças:

$\mathrm{Na}$ poesia hebraica, como eu afirmei anteriormente, pode ser observada uma certa conformação das sentenças, a natureza da qual é, que o senso completo é quase igualmente infundido em cada parte componente, e que cada parte constitui um verso inteiro [...]. ${ }^{53}$ (Lowth, s/d, p. 34)

Ele clarifica sua ideia na Leitura XIX:

A conformação poética das sentenças que tem sido tão frequentemente aludida como uma característica da poesia hebraica, consiste principalmente em uma certa igualdade, similaridade, ou paralelismo, entre os membros de cada período; então em duas linhas (ou membros do mesmo período), coisas em sua maior parte respondem a coisas, e palavras a palavras, como se ajustassem-se uma a outra por algum tipo de regra ou medida. ${ }^{54}$ (Ibid., p. 204-205)

\footnotetext{
52 "The modern study of Biblical poetry properly begins in 1753 with the seminal publication of Robert Lowth's De sacra poesi Hebraeorum."

53 "In the Hebrew poetry, as I before remarked, there may be observed a certain conformation of the sentences, the nature of which is, that a complete sense is almost equally infused into every component part, and that every member constitutes an entire verse [...]."

54 "The poetical conformation of the sentences which has been sooften alluded to as characteristic of the Hebrew poetry, consists chiefly in a certain equality, resemblance, or parallelism, between the members of each period; so that in two lines (or members of the same period), things for the most part shall answer to things, and words to words, as if fitted to each other by a kind of rule or measure."
} 
Lowth, entretanto, não foi o primeiro a notar o uso do que, a partir dele, passou a se chamar, tecnicamente, de paralelismo. (Cf. Cloete, 1989, p. 21) Abraham Ibn Ezra, sábio sefardi (aproximadamente 1089-1160), em seu comentário sobre o livro de Jó, destaca o paralelismo como um fator estilístico importante no mesmo. (Cf. Aranda, 2004, p. LVIII) Na sua interpretação de Jó 6:17, ele diz: "O correto em minha opinião é que neste versículo está repetido o sentido, como é habitual em versículos deste e de outros livros". ${ }^{55}$ (Ibid., p. 64) Inclusive, pela identificação desse contexto de paralelismo entre as linhas em Jó 6:17, ele indica que o sentido de יִזְר é "aquecer-se" - o que seria um hapax legomena - já que a complementação do verso traz o verbo חמם, que significa "fazer calor; esquentar". (Cf. Koehler e Baumgartner, 2001, p. 328)

Essa conclusão se dá porque Ibn Ezra entende que há uma paralelo

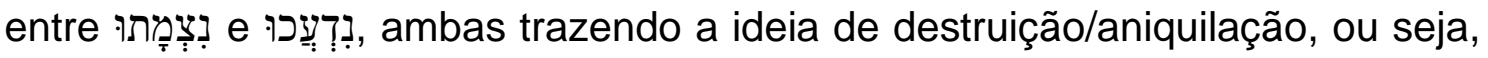
ele estende o paralelismo de dois termos para o restante do verso. (Cf. Aranda, 2004, p. 64-65) O próprio Lowth cita um outro rabino, Azarias, como uma 'autoridade' anterior a ele que entendia essa "proporção" entre sentenças nas "canções bíblicas". (Cf. Lowth, s/d, p. 214)

No desenvolvimento do seu conceito de parallelismus membrorum, Lowth apresenta o que seriam três tipos de paralelismo bíblico: o sinônimo, o antitético e o sintético.

O primeiro tipo seria definido como a estrutura em que o mesmo sentimento/ideia é repetido em termos diferentes, mas equivalentes. Ainda sobre o paralelismo sinônimo, o mais abundante e frequente dos três, o bispo reconhece haver variedade de formas do mesmo. (Cf. Ibid., p. 205-210) Como exemplo, ele cita, entre outros, $\mathrm{Na}$ 1:2 (cf. Ibid., p. 207-208):

JEHOVAH é Deus zeloso e vingador;

JEHOVAH é vingador e cheio de ira:

JEHOVAH se vinga de seus adversários;

E ele reserva indignação para seus inimigos." ${ }^{56}$

\footnotetext{
55 "Lo correcto en mi opinión es que en este versículo está repetido el sentido, como es habitual en los versículos de éste y otros libros."

${ }^{56}$ A tradução e versificação seguem o texto de Lowth: "JEHOVAH is a jealous and avenging God; / JEHOVAH avengeth, and is wrathful: / JEHOVAH avengeth his adversaries; / And he reserveth indignation for his enemies."
} 
paralelismo antitético seria quando algo é ilustrado pelo seu contrário, ou seja, seu oposto. (Cf. Ibid., p. 210-211) Exemplificando esse tipo, ele usa o texto de Is 65:13-14 (cf. Ibid., p. 211):

Eis, meus servos comerão, mas vós sereis famintos;

Eis, meus servos beberão, mas vós sereis sedentos;

Eis, meus servos regozijarão, mas vós sereis confusos;

Eis, meus servos cantarão alto de alegria no coração,

Mas vós chorareis alto de tristeza no coração

E na angústia do espírito quebrantado uivarão. ${ }^{57}$

Quanto ao terceiro tipo, o paralelismo sintético, assim define Lowth:

Há uma terceira espécie de paralelismo, no qual as sentenças respondem entre si, não pela repetição da mesma imagem ou sentimento, nem pela oposição de seus contrastes, mas meramente pela forma de construção. Quanto a ela, que pode ser chamado de Paralelismo Sintético ou Construtivo, pode ser atribuído tudo o que não está conectado nas categorias. ${ }^{58}$ (lbid., p. 211-212)

Ou seja, o paralelismo sintético seria quando a correspondência entre os dois segmentos não é imediatamente evidente. A explicação desse terceiro tipo de paralelismo, entretanto, é abrangente e obscura. (Cf. Harris, 2004, p. 2) O SI 19:8-11 $1^{59}$ é um dos exemplos dados por Lowth (s/d, p. 212):
A lei de JEHOVAH é perfeita, restaura a alma;
O testemunho de JEHOVAH é confiável, faz do simples sábio;
Os preceitos de JEHOVAH são retos, alegram o coração;
O mandamento de JEHOVAH é claro, ilumina os olhos;
O temor de JEHOVAH é puro, dura para sempre;
Os juízos de JEHOVAH são verdadeiros, todos eles são completamente justos:
Mais desejáveis que ouro, ou do que muito ouro fino;
E mais doces do que mel, ou do que o gotejar de favos de mel. ${ }^{60}$

\footnotetext{
${ }^{57}$ A tradução e versificação seguem o texto de Lowth: "Behold, my servants shall eat, but ye shall be famished;/ Behold, my servants shall drink, but ye shall be thirsty;/ Behold, my servants shall rejoice, but ye shall be confounded;/ Behold, my servants shall sing aloud for gladness of heart;/ But ye shall cry aloud for grief of heart,/ And in the anguish of a broken spirit shall ye howl."

58 "There is a third species of parallelism, in which the sentences answer to each other, not by the iteration of the same image or sentiment, or the opposition of their contraries, but merely by the form of construction. To this, which may be called the Synthetic or Constructive Parallelism, may be referred all such as do not come within the two former classes."

${ }^{59} \mathrm{Na}$ ARA, SI 19:7-10.

${ }^{60}$ A tradução e versificação seguem o texto de Lowth: "The law of JEHOVAH is perfect, restoring the soul; / The testimony of JEHOVAH is sure, making wise the simple; / The precepts of JEHOVAH
} 
É justamente o paralelismo sintético que, daquela época até os dias atuais, tem recebido maior atenção. A discussão, a partir de Lowth, gira em torno das distinções e especificações das diversas linhas paralelas que não se encaixam nas categorias de sinônimo ou antitético. (Cf. Petersen e Richards, 1992, p. 22)

Deste modo, os estudos produzidos sobre paralelismo nos últimos séculos são, essencialmente, uma reação às proposições de Robert Lowth, quer sejam para refinar suas definições e categorizações, ou para rejeitar suas análises e entender o fenômeno do paralelismo de um ponto de vista totalmente diferente. (Cf. Rogers, 2010, p. 10; Harris, 2004, p. 3) E, ainda que não seja o intento desse trabalho elaborar um estudo histórico sobre paralelismo, é importante apresentar brevemente a discussão sobre o assunto.

Em um artigo publicado em 1885, o professor Edward Curtis apresenta o que seriam as características principais da PHB. Segundo ele, apesar de desprovida de métrica e rima, a PHB possui ritmo e "uma certa uniformidade no tamanho e estrutura das linhas, além de um balanço de pensamento de uma linha sobre a outra", ${ }^{61}$ que ele denomina de paralelismo. (Curtis, 1885, p. 2) A subjetividade e a intensidade são as outras características realçadas por ele. (Cf. Ibid., p. 7)

Um ano depois, Charles Briggs apresenta uma série de artigos sobre PHB. Em seu primeiro artigo, apesar do foco principal ser a métrica, ao analisar o poema de $\mathrm{Nm}$ 23:7-10, enumera o que seriam, segundo ele, diversos paralelismos sinônimos, como por exemplo, 'Balaque' e o 'rei de Moabe' (23:7), 'Jacó' e 'Israel' (23:10), os verbos 'contar' e 'enumerar' (23:10), etc. Briggs, seguindo a ideia do parallelismus membrorum de Lowth, pondera que as linhas, apesar de variarem, mantêm sempre algum elemento (membro) em paralelo com a próxima linha. (Cf. Briggs, 1886, p. 164-166)

are right, rejoicing the heart; / The commandment of JEHOVAH is clear, enlightening the eyes; / The fear of JEHOVAH is pure, enduring for ever; / The judgments of JEHOVAH are truth, they are just altogether: / More desirable than gold, or than much fine gold; / And sweeter than honey, or the dropping of honey-combs."

61 "[...] a certain uniformity in the length and structure of lines, and the balancing of the thought of one line over against another [...]." 
George Buchanan Gray, em seu livro The Forms of Hebrew Poetry, de 1915, produz uma crítica pioneira, apontando a fraqueza da definição de Lowth, principalmente no que tange ao paralelismo sintético. (Cf. Kugel, 1981, p. 12) Para Gray, "o ponto vulnerável da exposição de Lowth sobre paralelismo como a lei da poesia hebraica está no que ele achou necessário compreender sob o termo paralelismo sintético [...]". ${ }^{62}$ (Gray, 1915, p. 49)

A maior parte do juízo de Gray se refere aos exemplos dados por Lowth, os quais, muitas vezes, nem apresentariam membros paralelos entre as linhas. (Cf. Ibid., p. 50) Mas apesar da crítica, ele considera sólida a exposição de Lowth acerca do paralelismo e busca, de fato, fazer uma reafirmação do conceito, apresentando alguns adendos. (Cf. Ibid., p. 52) Sua concordância com o parallelismus membrorum é tamanha que ele chega a dividir a literatura entre o que contém paralelismo - poesia - e o que não contém paralelismo prosa. (Cf. Rogers, 2010, p. 30)

Entre os adendos propostos estão tipos de paralelismo, como o completo e incompleto. O primeiro seria quando há a repetição de cada termo de uma linha em outra, como em Gn 49:7b (cf. Gray, 1915, p. 60):

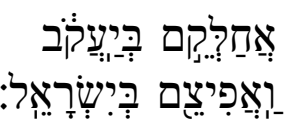

Eu vou dividi-los em Jacó; e vou espalhá-los em Israel. ${ }^{63}$

No exemplo acima, cada termo da primeira linha tem seu paralelo exato na segunda linha. (Cf. Rogers, 2010, p. 31) O segundo tipo, paralelismo incompleto, quando apenas alguns elementos se repetem, enquanto os outros termos expressam algo similar ao já dito (cf. Gray, 1915, p. 59), como ocorre em Is 1:26a (cf. Ibid., p. 75):

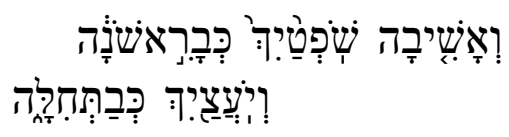

E Eu vou restaurar seus juízes como no princípio;

\footnotetext{
62 "The vulnerable point in Lowth's exposition of parallelism as the law of Hebrew poetry lies in what he found it necessary to comprehend under the term synthetic parallelism [...]."

${ }^{63}$ A divisão em versos segue a sugestão de Gray. $(1915$, p. 60$)$ Sua tradução do hebraico foi: "I will divide them in Jacob, / And I will scatter them in Israel."
} 
e seus conselheiros como no começo. ${ }^{64}$

Em 1929, Theophile James Meek, com um artigo intitulado The Structure of Hebrew Poetry, apontava alguns traços distintivos da PHB, entre eles o uso de termos arcaicos, elipses e a ausência do pronome relativo e do artigo definido. (Cf. Meek, 1929, p. 524) Agora, o traço distintivo que encontrava unanimidade entre os estudiosos da época, segundo Meek, era o paralelismo: "Se há algum único ponto no qual os estudiosos há muito têm concordado, é que o paralelismo é a marca característica do verso hebraico e um importante diferencial entre prosa e poesia". ${ }^{65}$ (Ibid., p. 528)

Meek entende que o paralelismo pode ir além do par de linhas, abrangendo três ou quatro linhas, desde que mantendo a mesma unidade de pensamento. (Cf. Ibid., p. 529) Ele também amplia a classificação dos tipos de paralelismo para além dos três propostos por Lowth, incluindo as categorias de paralelismo completo e incompleto (cf. Ibid., p. 530), no que parece reproduzir Gray.

\subsection{A REAFIRMAÇÃO: QUESTIONAMENTO DAS DEFINIÇÕES E NOMENCLATURAS}

Hans Kosmala, teólogo alemão que dirigiu o Swedish Theological Institute em Jerusalém durante cerca de vinte anos, propõe uma nova aproximação da PHB, aproximação essa que deveria se concentrar em duas características poéticas: a regularidade do número de palavras (ou unidades de palavra) em cada sentença e a composição correspondente entre as linhas, não somente em comprimento, mas também em conteúdo. Sua percepção é que a forma e o conteúdo poético caminham em conjunto. (Cf. Kosmala, 1964, p. 424-425) Ele atesta:

O uso de duas orações paralelas em uma sentença ou linha e - princípio da palavra-unidade junto com a íntima correspondência entre forma e estrutura, ou ainda mais, forma e o arranjo de ideias na composição como um todo, a qual

\footnotetext{
${ }^{64}$ A divisão em versos segue a sugestão de Gray. (1915, p. 75) Sua tradução do hebraico foi: "I will restore thy judges as at the first, / And thy counsellors as at the beginning."

65 "If there is any one point on which scholars have long been agreed, it is that parallelism is the characteristic mark of Hebrew verse and an important differentia between prose and poetry."
} 
novamente, como nós iremos ver, cria um novo paralelismo distinto daquele dentro da linha, a saber, o de linhas correspondentes dentro da composição - essas são as características distintivas da poesia ugarítica (segundo milênio a.e.c.) assim como também na poesia hebraica até tempos exílicos. ${ }^{66}$ (Ibid., p. 427)

Como Lowth, ele também se remete ao rabino Azaryah de Rossi ${ }^{67}$ como um pioneiro no estudo da PHB. Para Kosmala, o princípio fundamental estabelecido pelo rabino era que o elemento básico da PHB seria a palavra, ou palavra-unidade. Sua crítica a Lowth é que, apesar de ter explicitado bem o fenômeno do paralelismo, não aplicou esse princípio da palavra-unidade em sua análise da PHB. (Cf. Ibid., p. 425-427)

A recuperação da literatura ugarítica, mencionada por Kosmala acima, deu novo impulso aos estudos bíblicos, em especial aos estudos da PHB. Desde $1934,{ }^{68}$ a observação de que tanto a poesia ugarítica quanto a poesia hebraica guardavam diversas similaridades, como o uso abundante do paralelismo, revelou uma série de possibilidades comparativas. (Cf. Yoder, 1971 , p. 470-472 e Korpel e de Moor, 1988, p. 1)

Além disso, os estudos de Roman Jakobson sobre paralelismo, principalmente em dois artigos, Poesia da gramática e gramática da poesia (publicado em russo em 1961; traduzido e publicado em português em 1970) e Grammatical Parallelism and Its Russian Facet (1966), abriram portas para um novo tipo de abordagem do paralelismo. (Cf. Tsumura, 2009, p. 167-168; Cross, 1983, p. 129) Nesses estudos, Jakobson demonstrava a presença do paralelismo como um importante elemento em diversas literaturas, como a finlandesa e a russa. (Cf. Geller, 1979, p. 1-2)

\footnotetext{
66 "The use of two parallel clauses in a sentence or line and the principle of the word-unit together with the close correspondence between form and structure, or rather, form and the arrangement of ideas in the composition as a whole, which again, as we shall see, creates a new parallelism apart from the one within the line, namely that of corresponding lines within the composition - these are the distinctive features in Ugaritic poetry (2nd millenium B.C.) as well as in ancient Hebrew poetry down to exilic times."

${ }^{67}$ Ver a nota 41.

${ }^{68}$ Perry Yoder cita uma série de artigos de H. L. Ginsberg, o pioneiro do assunto. (Cf. Yoder, 1971,470, n. 2,3 e 4)
} 
Jakobson argumenta que o paralelismo expresso na arte poética franqueia uma visão direta das concepções de equivalência, similaridade e discrepância tanto sintática, quanto morfológica e léxica dentro da língua. (Cf. Jakobson, 1970 , p. 70$)^{69}$ Ele afirma enfaticamente:

Um problema poético e linguístico de tamanha importância como o paralelismo dificilmente poderá ser tratado com eficácia se sua análise ficar automaticamente restrita à forma externa e for excluída toda e qualquer discussão dos significados gramaticais e lexicais. (lbid.)

Stephen Geller aponta o artigo de 1966 (mencionado acima) de Roman Jakobson como o principal estímulo para sua busca por um método que isolasse as primordiais estruturas gramáticas e semânticas do verso paralelo. (Cf. Geller, 1979, p. 1-3, 6) Mas embora Jakobson falasse que as estruturas fonológicas, gramaticais e semânticas do paralelismo estivessem além das linhas paralelas e permeassem todo o texto (cf. Jakobson, 1966, p. 423), Geller argumenta que a aplicação na PHB seria quase impossível e enumera dificuldades que vão desde a pronúncia ${ }^{70}$ até a falta de estudos sistemáticos sobre o paralelismo gramatical. (Cf. Geller, 1979, p. 2-3) Por isso ele se limitaria, inicialmente, ao par de linhas (A e B) e não a todo o poema. (Cf. Ibid., p. 16)

Então, paralelismo envolveria um relacionamento primariamente binário entre as linha $A$ e $B$, sendo possível, a princípio, reduzir o par de linhas em uma única afirmação, que foi expressa binariamente. (Cf. Ibid.) Sua explicação dessa redução é:

Para cada exemplo, alguém pode restaurar, ou 'reconstruir', a afirmação hipoteticamente unitária arranjando as linhas $A$ e $B$ de maneira que as unidades semanticamente paralelas apareçam nas mesmas posições e em uma estrutura sequencial sintagmática a qual também inclui elementos não paralelos. ${ }^{71}$ (lbid.)

\footnotetext{
${ }^{69} \mathrm{Em}$ outro artigo, intitulado Configuração verbal subliminar em poesia, Jakobson volta a insistir na complexidade do sistema de correspondência e em quão intuitivo ele pode ser. (Cf. Jakobson, 1970, p. 91-92)

${ }_{71}^{70}$ Geller aponta a possível distorção da vocalização Massorética. (Cf. Geller, 1979, p. 2)

71 "For each example, one can restore, or 'reconstruct', the hypothetical unitary statement by arranging $A$ and $B$ lines in such a way that semantically parallel units appear in the same positions and in a sequential syntagmatic structure which also includes non-parallel elements."
} 
A 'reconstrução' gramatical das linhas visa perceber se existe paralelismo ou apenas uma compatibilidade. (Cf. Ibid.) Por exemplo, se houvesse um paralelismo semântico entre as linhas $A$ e $B$, mas a gramática ou sintaxe não fosse coincidente, ele transformaria ou reconstruiria as linhas, geralmente a segunda, B. (Cf. Rogers, 2010, p. 45-46)

No segundo apêndice de sua obra (aonde critica o paralelismo sintático nos termos de Lowth), Geller conclui dizendo que o "paralelismo, como recurso poético, significa que deve-se sempre entender uma dada linha $B$, tanto quanto possível, em termos da linha $A$ correspondente, tanto semanticamente quanto gramaticalmente".$^{72}$ (Geller, 1979, p. 385)

Um ponto a ressaltar é a categorização extensa feita por Geller ao se referir ao paralelismo semântico. Ele apresenta as seguintes categorias simples para o paralelismo: sinônimo, lista, antitético, merisma, epíteto, pronominal, numérico, concreto-abstrato, todo-parte, nome próprio, metafórico. (Cf. Ibid., p. 34-38) Além dessas, ainda apresenta as categorias "modificadas" e as "compostas". (Cf. Ibid., p. 38-41)

Geller registra que o paralelismo 'sinônimo' não é mera repetição, mas uma repetição variada onde os termos podem ser descritos como sinônimos. Ele acrescenta que, mesmo sendo sinônimos, um olhar mais cuidadoso revela diferenças de 'tom'. (Cf Geller, 1979, p. 34-35) O exemplo dado é Gn 4:23a (cf. Geller, 1979, p. 35):

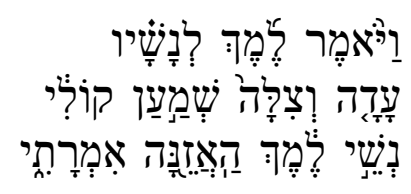

E disse Lameque ${ }^{73}$ para suas mulheres:

Ada e Zilá, escutai minha voz;

mulheres de Lameque, dai ouvidos ao meu discurso. ${ }^{74}$

\footnotetext{
72 "[...] parallelism as a poetic device means that one must always understand a given $B$ line as much as possible in terms of its A line, both semantically and grammatically."

${ }_{74}^{73}$ Nomes próprios seguem a tradução da ARA

74 Geller não apresenta o verso em hebraico e nem sua tradução. Ele apenas cita os termos que estariam em paralelo. No caso, 'voz' (קל) e 'discurso' (אמרה). Nas notas seguintes, indicarei os termos destacados por Geller. (1979, p. 35)
} 
Na categoria 'lista' estão os membros paralelos que possuem um mesmo campo semântico, mas não podem permutar, gerando um efeito de enumeração, como, segundo Geller, ocorre em Gn 4:23b (cf. Ibid.):

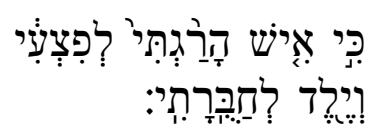

pois um homem matei por me causar ferida;

e um adolescente por me dar uma pancada. ${ }^{75}$

O paralelismo 'antitético' é pertencente ao paradigma no qual a "identidade básica" do termo é substituída pela "não identidade", como Geller indica em Dt 32:25a (cf. Ibid.):

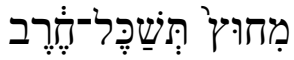

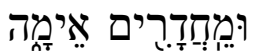

Lá fora desolará a espada;

e nas câmaras terror. ${ }^{76}$

Uma outra categoria de paralelismo revelado por Geller é a 'merisma'. Ele o relaciona com o paralelismo antônimo, mas especifica que no paralelismo merismático a afirmação opõe dois extremos para implicar tudo entre eles. (Cf. Geller, 1979, p. 35) Um dos dois exemplos dados por ele é Dt 32:1 (cf. Ibid., p. 36):

Dai ouvidos, céus, e eu falarei;

e escuta, terra, as palavras da minha boca. ${ }^{77}$

Na categoria de 'epíteto', o paralelismo ocorre pela descrição em rodeios de algo na linha B que é explícito ou claro na linha A. Geller não lista nenhum texto da BH como exemplo. Em seguida, na categoria de 'nome próprio', onde

75 Os termos paralelos indicados por Geller são: 'homem' (איש:) e 'jovem' (ילד). (p. 35)

${ }^{76}$ Os termos paralelos indicados por Geller são: 'lá fora' (מחוץ) e 'câmaras' (מחדים). (מחדרים) (p. 35)

77 Os termos paralelos indicados por Geller são: 'céus' (שמים) e 'terra' (ארץ). (p. 36) 
um substantivo próprio é pareado com um substantivo comum, como em Gn 49:16 (cf. Ibid.):

Dã julgará seu povo;

como um das tribos de Israel. ${ }^{78}$

Uma similar à do exemplo acima é a 'pronominal', quando pronomes de mesmo "antecedente" são colocados em paralelo, tal qual Jz 5:29 (cf. Ibid.):

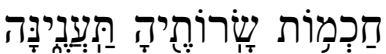

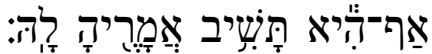

A mais sábias de suas damas respondem-na; também a ela fazem retornar suas próprias respostas. ${ }^{79}$

A característica da categoria 'todo-parte' é que um membro do paralelo abrange semanticamente o outro. Basicamente, é uma sinédoque, tipo específico de metonímia. Um dos exemplos dados por Geller é Dt 33:29c (cf. Ibid.):

A nona categoria das onze propostas por Geller é a 'concreto-abstrato, que coloca um termo mais geral e abstrato em paralelo com outro mais

\footnotetext{
78 Os termos paralelos indicados por Geller são: 'seu povo' (עמוi) e 'tribos de Israel' ( שבטי ישראל). (p. 36)

${ }^{79}$ Os termos paralelos indicados por Geller são: 'as mais sábias de suas damas' ( חַכְמוֹת

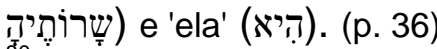

${ }^{80}$ Tradução segue indicação de Geller.

81 Os termos paralelos indicados por Geller são: 'seus inimigos' (איביך) e 'sobre suas costas' (על־במוֹתימו) (p. 36)
} 
concreto e que está contido na ideia do termo abstrato. Isso ocorre, conforme Geller, em Dt 32:25a (cf. Ibid., p. 37):

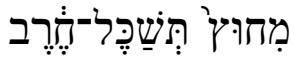

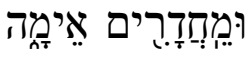

Lá fora desolará a espada;

e nas câmaras terror. ${ }^{82}$

A penúltima categoria é a 'numérica'. É uma variação da 'lista' em que os números são pareados, sem que sejam semanticamente paralelos, como em Dt 32:30a (cf. lbid.):

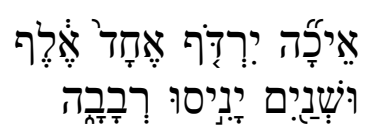

Como perseguiria um a mil;

e dois colocariam em fuga dez mil. ${ }^{83}$

Por fim, Geller fala do paralelismo metafórico, que sucede quando os termos estão relacionados metaforicamente dentro de um contexto estabelecido dentro do par de linhas. Geller cita SI 68:3b-c como exemplo (cf. lbid., p. 38):

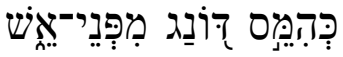

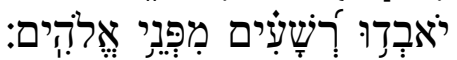
como cera derretida diante do fogo; perecerão os perversos diante de Deus.$^{84}$

Cerca de um ano depois, David Noel Freedman publicou o livro Pottery, Poetry, and Prophecy, com uma série de artigos/ensaios que ele mesmo havia apresentado ao longo da década de 1970. Para Freedman, a importância da PHB é seu uso como evidência de datação da BH. (Cf. Freedman, 1980, p. 4-6) Isso porque, através da comparação entre os textos (principalmente com 0

82 Os termos paralelos indicados por Geller são: 'espada' (חרב) e 'terror' (אימה). (p. 37)

83 Os termos paralelos indicados por Geller são: 'um' (אחד) e 'dois' (שנרבים). (p. (קנד)

${ }^{84}$ Os termos paralelos indicados por Geller são: 'cera' (דשוֹג) e 'perversos' (רשגים). (p. 38) 
Ugarítico), seria possível indicar as semelhanças e estabelecer a prosódia hebraica bíblica. (Cf. Petersen e Richards, 1992, p. 15)

A contribuição de Freedman para a discussão sobre paralelismo se dá em seu artigo Prolegomenon em uma reimpressão do livro de George B. Gray, The Forms of Hebrew Poetry, em 1972. Ali, Freedman repassa as contribuições de Gray para o estudo da PHB, exaltando a flexibilidade nas definições do estudioso inglês, principalmente no que se refere à classificação de paralelismo completo e incompleto. A classificação de Gray de paralelismo completo e incompleto, segundo Freedman, resultaria na percepção de que o paralelismo não é o único critério definidor do verso bíblico e, na verdade, nem seria uma característica necessária à PHB. (Cf. Freedman, 1980, p. 36-37)

\subsubsection{Michael O'Connor: inovação nOMEnClatória e nOVA PROPOSta DESCRITIVA}

Hebrew Verse Structure, uma tese doutoral retrabalhada (cf. Holladay, 1999, p. 20) e lançada como um "ensaio" (cf. O'Connor, 1997, p. 1) em 1980 por Michael O'Connor, é um marco por sua extensão e pela tentativa de trazer uma nova nomenclatura e uma nova dinâmica ao estudo da PHB e do paralelismo. (Cf. Holladay, 1999, p. 19-20)

O'Connor apresenta seu entendimento do verso hebraico em contraste com o que ele chama de "Descrição Padrão do verso Hebraico". ${ }^{85}$ Essa "Descrição Padrão" é atribuída, fundamentalmente, a Lowth e seus sucessores. (Cf. O'Connor, 1997, 4-5) Ele, inclusive, chega a fazer uma distinção entre a "Descrição Padrão" e a "descrição nativa", ${ }^{86}$ sendo a segunda relativa às indicações esticométricas tradicionais presentes na $\mathrm{BH}$ - trechos já divididos em versos no texto Massorético, como os livros de Jó, Provérbios e Salmos, além de outros poucos poemas, como Ex 15, Dt 32 e 33, Jz 5 e 2 Sm 22. (Cf. Ibid., p. 29-30)

\footnotetext{
${ }^{85}$ A expressão usada por ele é "Standard Description of Hebrew verse".

${ }^{86}$ A expressão usada por O'Connor é "native description".
} 
A percepção essencial de Lowth, segundo O'Connor, é que o verso hebraico está assentado em duas bases: linhas contíguas (que Lowth chama de paralelismo) e as próprias linhas (que Lowth chama de métrica). O'Connor observa: "Nos duzentos e vinte cinco anos desde que as conferências de Lowth foram publicadas, eruditos e estudantes buscaram refinar sua tipologia do paralelismo e especificar a natureza da base métrica". (Ibid., p. 32-33) Entretanto, essa busca, de acordo com O'Connor, resultaria em um mistério obscuro - a métrica - e outro somente um pouco menos obscuro - o paralelismo. (Cf. Ibid., p. 33)

A principal crítica de O'Connor ao paralelismo de Lowth é que o mesmo é somente descrito em termos unicamente semânticos e em relação a realidades não-verbais. A própria nomenclatura 'paralelismo' é questionada ("a objeção mais óbvia") ${ }^{87}$ e o efeito classificado como indefinível, visto cobrir tantos fenômenos linguísticos. (Cf. Ibid., p. 50-51)

O'Connor, como Geller, cita o seguinte texto de Jakobson ao tratar da extensão do paralelismo como um fenômeno além da semântica (cf. Geller, 1979, p. 1; O'Connor, 1997, p. 89):

Paralelismo penetrante inevitavelmente ativa todos os níveis da linguagem - as características distintivas (fonológicas), ambas inerentes e prosódicas, as categorias e formas morfológicas e sintáticas, as unidades lexicais e suas classes semânticas tanto em suas convergências quanto divergências adquirem um valor poético autônomo. ${ }^{88}$ (Jakobson, 1966, p. 423)

Ao mesmo tempo, ele reconhece que a descrição de Lowth do paralelismo como um componente estrutural importante da PHB não é totalmente equivocada, mas acrescenta que a problemática é a definição simplória. (Cf. O'Connor, 1997, p. 88-89) Nas palavras de O'Connor:

Nós estamos preocupados com o paralelismo como um componente da descrição estrutural da poesia; se houvesse uma única característica do paralelismo, que é um importante

\footnotetext{
87 "The most obvious objection [...]."

88 "Pervasive parallelism inevitably activates all the levels of language - the distinctive (phonological) features, both inherent and prosodic, the morphological and syntactic categories and forms, the lexical units and their semantic classes in both their convergences and divergences acquire an autonomous poetic value."
} 
mecanismo estruturante do sistema do verso, ela estaria disponível para definição e consideração.

Não existe tal definição porque não existe uma única característica. Antes, um pequeno grupo de elementos paralelísticos são centrais para o sistema e todos os outros ocorrem esporadicamente. ${ }^{89}$ (Ibid., p. 89)

Ele também declara:

Nós vamos sustentar que a estrutura poética é determinada por um certo fenômeno paralelístico, o qual chamamos de tropos. Há muitos outros fenômenos paralelísticos, que se dividem em dois grupos: (a) aqueles que são raros e menores e pertencem ao reina da figuração e da ornamentação; (b) aqueles que resultam da co-ocorrência dos tropos. ${ }^{90}$ (lbid., p. 96)

As colocações de O'Connor parecem levar o leitor à dúvida sobre qual o pensamento dele sobre paralelismo. De um lado parece diminuir a importância do fenômeno na estrutura do verso e de outro, ele o afirma como estrutural. $\mathrm{O}$ que ocorre é que O'Connor percebe o sistema estrutural do verso da PHB como uma base restritiva definida em termos sintáticos a qual tropos paralelísticos são colocados sobre. Essa percepção parece assemelhar-se da percepção de Lowth que via a métrica como complementar ao paralelismo na formação da PHB. (Cf. Leatherman, 1998, p. 106-107)

Ou seja, a perspicácia crucial de Lowth, na visão de O'Connor, foi concluir que o padrão da PHB é criado pela interação entre dois sistemas recorrentes. (Cf. O'Connor, 1997, p. 4) O que Lowth entende como métrica, baseado em fonologia, O'Connor entende como um "sistema sintático de restrições". Ambos apontam que o segundo ${ }^{91}$ sistema recorrente é o paralelismo, o qual O'Connor chama de tropo. (Cf. Leatherman, 1998, p. 107)

\footnotetext{
89 "We are concerned with parallelism as a component of structural description of poetry; if there were a single feature of parallelism which is a major structuring device of the verse system, it would be available for definition and close consideration. No such definition exists because no single feature exists. Rather, a small group of parallelistic features are central to the system and all others accur sporadically."

90 "We will contend that poetic structure is determined by certain parallelistic phenomena which we call tropes. There are many other parallelistic phenomena which fall into two groups: (a) those which are rare and minor and belong to the realms of figuration and ornamentation and (b) those which result from the cooccurrence of tropes."

${ }^{91}$ É preciso esclarecer que não se trata de hierarquia.
} 
O'Connor reivindica que o paralelismo pode ser desmantelado em partes e ser examinado a partir disso, o que, segundo ele, não era um processo acessível a Lowth e que só se tornou possível graças aos avanços acadêmicos modernos, principalmente através do conhecimento de outros tipos de poesia além da ocidental. (Cf. O’Connor, 1997, p. 87)

Entretanto, o paralelismo, e os tropos paralelísticos que O'Connor busca isolar, não são apenas fenômenos puramente sintáticos e também são determinados por considerações semânticas, ainda que a sintaxe exerça sempre algum papel nessas situações. (Cf. Leatherman, 1998, p. 117)

Os tropos da exposição de O'Connor podem ser divididos em dois grupos: tropos do paralelismo - coloração, duplicação, mistura; e tropos de continuidade - repetição, elipse e dependência. Essa divisão não evita que haja uma pequena superposição entre elipse e duplicação e que combinação esteja contida em dependência. (Cf. O’Connor, 1997, p. 87-88)

Coloração consiste em qualquer caso de binômino, coordenação e combinação. O primeiro caso, binômio, se refere ao uso de dois termos se referindo à mesma entidade em linhas consecutivas, como por exemplo, אֶלדהים

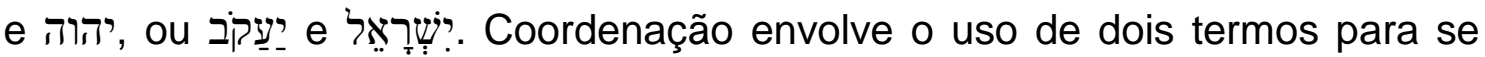
referir a duas entidades diferentes, mas que sejam frequentemente associadas

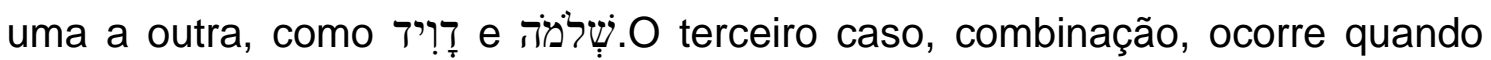
uma frase consiste de termos frequentemente associados, e estes são divididos em duas linhas. (Cf. Leatherman, 1998, p. 117-118)

Duplicação seria, como aponta O'Connor, o fenômeno que muitos associam com o paralelismo. É quando as linhas possuem estrutura sintática idêntica, como por exemplo, o SI 106:35b-36a (cf. O'Connor, 1997, p. 119-120):

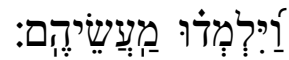

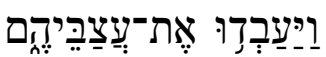

E eles aprenderam seus trabalhos.

E eles serviram seus ídolos. ${ }^{92}$

92 A divisão em versos segue a sugestão de O'Connor. (1997, p. 120) Sua tradução do hebraico foi: "They learned their customs. / They worshipped their idols." 
O tropo da mistura é definido assim por O'Connor:

O tropo da mistura envolve duas linhas dependentes e duas independentes que ocorrem em uma sequência, na qual as duas linhas dependentes dependem das duas independentes. Esta é a característica estrutural mais densa do verso hebraico e é rara. ${ }^{93}$ (Ibid., p. 132)

Um exemplo dado por ele é o SI 106:47 (cf. Ibid., p. 132):

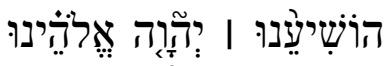

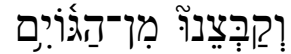

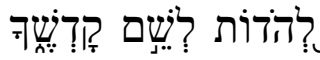

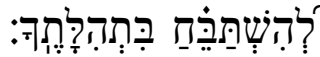

Salva-nos YHWH nosso Deus, e nos reúna de entre as nações, para render graças ao nome da Tua santidade, para louvar em teu louvor. ${ }^{94}$

Pode-se perceber que o tropo coloração funciona entre palavras, o tropo da duplicação entre as linhas e o tropo da mistura envolve estruturas maiores do que as linhas. Assim também funcionam os tropos da continuidade. (Cf. Leatherman, 1998, p. 118)

O tropo da repetição é autoexplicativo. Consiste no uso de expressões idênticas assiduamente. Esse tropo se dá no nível da palavra e é o único que O'Connor reconhece como funcionando contiguamente. Ainda assim, ele estabelece limites para este tropo: é preciso ser o mesmo lexema atuando na mesma função sintática. (Cf. Ibid.)

A elipse é o tropo que funciona no nível da linha e consiste na supressão de uma palavra ou expressão da estrutura de uma das linhas consecutivas, geralmente a segunda. A elipse mais frequente na PHB é a do verbo. (Cf.

\footnotetext{
93 "The trope of mixing involves two dependent and two independent lines which occur in sequence, in which both dependent lines depend on both independent clauses. This is the densest structural feature of Hebrew verse and it is rare."

${ }^{94}$ A divisão em versos segue a sugestão de O'Connor. (1997, p. 132) Sua tradução do hebraico foi: "Save us, Yahweh our god, / Gather us from the nations, / To praise your holy name,/ to laud (you) for your triumphs."
} 
O'Connor, 1997, p. 122-129) Ele cita o SI 78:51 como exemplo da elipse de verbo (cf. Ibid., p. 128):

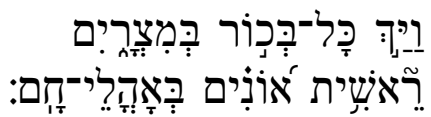

Ele afligiu todos os primogênitos no Egito, o primórdio da força nas tendas de Hām. ${ }^{95}$

Por fim, dependência envolve linhas consecutivas ou próximas, sendo que uma é sintaticamente dependente da outra. Esse tropo é raro e, como sugere O'Connor, menos importante: "Ao considerar a dependência como um tropo sugere-se que as relações sintáticas além da linha são menos importantes no verso hebraico do que aquelas que coincidem com a linha; isso é verdade" ${ }^{96}$ (Ibid., p. 129)

Toda essa definição dos tropos - nomenclatura utilizada somente por O'Connor e que se refere, basicamente, ao paralelismo (cf. Kugel, 1981, p. 316) - tem duas funções principais dentro da lógica de O'Connor: amarrar as linhas do verso e marcar um texto como poético. (Cf. Leatherman, 1998, p. 120)

\subsubsection{JAMES KUGEL: A CRÍTICA DAS DEFINIÇÕES}

No ano seguinte à publicação da obra de O'Connor, James Kugel retoma a análise do conceito de paralelismo proposto por Lowth e vê problemas não somente no paralelismo sintético (como Gray e outros), mas nos dois outros tipos também. Para ele a própria definição do paralelismo sinônimo acarreta um equívoco, pois simplesmente deduz que a linha B é uma confirmação da linha A: "Paralelismo se torna, então, dizer a mesma coisa duas

\footnotetext{
95 A divisão em versos segue a sugestão de O'Connor. (1997, p. 128) Sua tradução do hebraico foi: "He killed every first born child in Egypt, / (he killed) the first fruits of their strength in the tents of Ham."

96 "Considering dependency as a trope suggests that syntactic relations beyond the line are less important in Hebrew verse than those that coincide with the line; this is true."
} 
vezes". ${ }^{97}$ (Kugel, 1981, p. 12-13) Quanto ao paralelismo antitético, sua crítica é que A e B "se tornam versões independentes (opostas) da 'mesma ideia'."18 (Ibid., p. 13), ${ }^{99}$ ou seja, ao invés de criarem contraste (como a nomenclatura sugere), proporcionam harmonia. (Cf. Ibid., p. 14)

As definições de Lowth dos tipos de paralelismo são, segundo Kugel, confusas e trouxeram efeitos desastrosos sobre a real natureza do paralelismo bíblico nos estudos subsequentes. (Cf. Kugel, 1981, p. 15) Para ele, o próprio uso do termo "paralelismo" é enganoso, pois implicaria, necessariamente, em um paralelo entre metades, o que não chegaria a ocorrer (cf. Ibid., p. 2), no que soa como um eco da crítica da mesma crítica feita por O'Connor.

Para Kugel, a essência do paralelismo está distante de qualquer tipo de paralelo entre as linhas: "[...] linhas bíblicas são paralelísticas não porque $B$ seja supostamente paralela a $A$, mas porque $B$ tipicamente apoia $A$, levando-a adiante, dando suporte a ela, completando-a e indo além dela". ${ }^{100}$ (Ibid., p. 52) Portanto, a similaridade entra elas é, na verdade, um argumento contra a similaridade entre elas. Isto é, o que as aproxima é o que as afasta. Nas palavras dele:

O que isso significa é simples: $B$, por estar conectado a $A$ carregando-a além, ecoando-a, definindo-a, reafirmando-a, contrastando-a, não importa o que - tem um caráter enfático "secundário" e é isso, mais do que qualquer estética de simetria ou de paralelo, que está no coração do paralelismo bíblico. ${ }^{101}$ (Ibid., p. 51)

Kugel propõe quatro exemplos para demonstrar que todo paralelismo consiste de "A, uma pausa, e a continuação de A, B (ou B + C)". ${ }^{102}$ (Cf. Ibid., p.

\footnotetext{
97 "Parallelism, then, became 'saying the same thing twice' [...]."

98 "[...] become independent (opposite) versions of 'the same idea' [...]."

99 Krašovec possui definição parecida - o paralelismo antitético não é a contradição ou negação, mas o aspecto oposto de uma mesma ideia. (Cf. Krašovec, 1984, p. 4-6) Mas, ao contrário de Kugel, ele busca não somente demonstrar o paralelismo antitético na PHB, mas o conceito de antítese para além do verso. (Cf. Ibid., p. 137) Krašovec também apresenta uma lista de estruturas antitéticas na $\mathrm{BH}$ e até tenta criar categorias para o paralelismo antitético. (Cf. Ibid., p. 124-130)

100 "[...] biblical lines are parallelistic not because $B$ is meant to be parallel of $A$, but because $B$ typically supports $A$, carries it further, backs it up, completes it, goes beyond it."

101 "What this means is simply: $B$, by being connected to $A$ - carrying it further, echoing it, defining it, restating it, contrasting with it, it does not matter which - has an emphatic, 'seconding' character, and it is this, more than any aesthetic of symmetry or paralleling, which is at the heart of biblical parallelism."

102 "[...] A, a pause, and A's continuation $B($ or $B+C)$."
} 
57-58) Os exemplos são o SI 98:1 (primeira parte); SI 96:1; SI 149:1 e SI 33:3, listados respectivamente abaixo (cf. Ibid., p. 58):

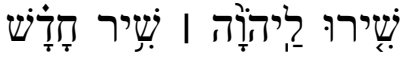

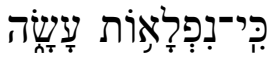

Cantai para YHWH uma canção nova

pois maravilhosos são seus feitos.$^{103}$

Cantai para YHWH uma canção nova

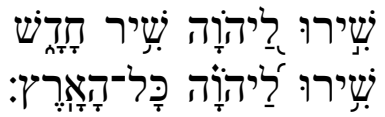

Cantai para YHWH toda a terra. ${ }^{104}$

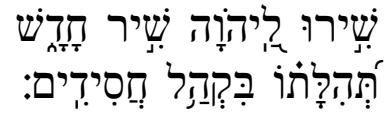

Cantai para YHWH uma canção nova

Seu louvor na congregação dos fiés. ${ }^{105}$

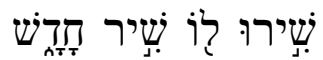

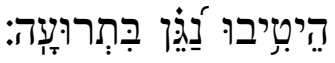

Cantai para YHWH uma canção nova tangei artisticamente em alegria. ${ }^{106}$

Com esses exemplos, Kugel pretende demonstrar que, estruturalmente, não há diferenciação significativa entre esses versos e, ao mesmo tempo, que as diferenças entre eles não podem ser expressas em termos de categorias. Ele conclui: "Paralelismo bíblico é de um tipo, 'A, e ainda mais, $B$ ' ou de centenas de tipos; mas não de três". ${ }^{107}$ (Ibid., p. 58)

Em um apêndice de seu livro, Kugel elabora uma reflexão sobre a obra de O'Connor, então recém-lançada. Ele concorda com O'Connor na crítica às

\footnotetext{
${ }^{103}$ A divisão em versos segue a sugestão de Kugel. (1981, p. 58) Sua tradução do hebraico foi: "Sing another song of the Lord / how he has worked wonders."

${ }^{104}$ A divisão em versos segue a sugestão de Kugel. (1981, p. 58) Sua tradução do hebraico foi: "Sing another song of the Lord / sing of the Lord all the earth."

${ }^{105}$ A divisão em versos segue a sugestão de Kugel. (1981, p. 58) Sua tradução do hebraico foi: "Sing another song of the Lord / [sing] his praise in a company of the faithful."

${ }^{106}$ A divisão em versos segue a sugestão de Kugel. (1981, p. 58) Sua tradução do hebraico foi: "Sing another song of the Lord / play a goodly tune."

107 "Biblical parallelism is of one sort, 'A, and what's more, B' or a hundred sorts; but it is not three."
} 
categorias de Lowth e na argumentação contra a definição de paralelismo. (Cf. Ibid., p. 315) Entretanto, considera que apesar das críticas, O'Connor apenas redefine os conceitos da PHB com "alterações radicais", ao invés de prosseguir com seu questionamento da própria ideia de PHB. (Cf. Ibid., p. 316) Kugel considera que isso poderia levar a proposta de O'Connor pelo mesmo caminho do objeto da sua crítica. (Cf. Ibid., p. 323)

Por isso, o juízo central de Kugel ao método de O'Connor se baseia na omissão dele em discutir a distinção entre prosa e poesia na $\mathrm{BH}$ : " $A$ inabilidade desta descrição para descrever alguma diferença entre poesia e prosa está longe de ser uma irrelevância ou um pequeno defeito: chama a um questionamento de todo o projeto". ${ }^{108}$ (Ibid., p. 319)

Kugel também considera que a abordagem de O'Connor quanto ao paralelismo é, por vezes, de uma simplificação excessiva, principalmente do conceito de elipse. (Cf. Ibid., p. 322) E, a despeito de considerar a contribuição de O’Connor substancial quanto à análise sintática do hebraico (cf. Ibid., 323), ele afirma:

A aproximação do paralelismo de O'Connor, instrutiva como é, consegue obscurecer a única coisa que foi mais valiosa no 'paralelismo' de Lowth - seu agrupamento de uma variedade de procedimentos sob uma simples assinatura por seus efeitos básicos de similaridade. ${ }^{109}$ (Ibid., p. 322)

De maneira geral, Kugel parece concordar com O'Connor quanto ao caráter do paralelismo. (Cf. Berlin, 1985, 147, n. 11) Enquanto o segundo afirma: "A maior parte do uso do paralelismo resulta de fatos ordinários da linguagem, não de características poéticas específicas". ${ }^{110}$ (O’Connor, 1997, p. 101); o primeiro parece corroborar dizendo: "Por isso, não há nada 'poético' ou literário nos pares per se [...]". ${ }^{111}$ (Kugel, 1981, p. 33-34) Ou seja, embora reconheça o paralelismo como um fenômeno da linguagem hebraica, Kugel

\footnotetext{
108 "The inability of this description to describe any difference between poetry and prose is far from an irrelevancy or a minor defect: it calls into question the entire undertaking."

109 "O'Connor's approach to parallelism, enlightening as it is, thus succeeds in obscuring the one thing that was most valuable in Lowth's 'parallelism - its grouping of a variety of procedures under a single rubric because of their basic effective similarity."

110 "Most parallelistic usages result from ordinary facts of language, not specific poetic features."

111 "Thus, there is nothing 'poetic' or literary in the pairs per se [...]."
} 
não o aceita como um indicativo da existência de PHB ou como recurso exclusivo da mesma.

\subsubsection{WILFRED WATSON: MANUAL DE ESTILO E TIPOLOGIA EXTENSIVA}

Wilfred Watson, em seu Classical Hebrew Poetry: a guide to its techniques (1984), propõe um manual ou "livro-texto" de PHB. (Cf. Watson, 1984, p. 1) Seu objetivo com o manual não é nem uma análise linguística nem literária, mas estilística. (Cf. Ibid., p. 3) ${ }^{112}$

Para tanto, Watson vai estabelecer logo de início três bases: a relação da PHB com a poesia de outras línguas semíticas, mais precisamente o acadiano e o ugarítico (Cf. Ibid., p. 4-10); uma terminologia explicativa antecipada (Cf. Ibid., p. 11-15); e um método baseado em catorze passos (Cf. lbid., p. 15-20).

Sobre o primeiro aspecto, ele assevera: "Para um mais completo entendimento das técnicas poéticas usadas na poesia hebraica clássica algumas comparações serão feitas [... $]^{113}$ (lbid., p. 4) As razões para a comparação entre as literaturas poéticas hebraica, acadiana e ugarítica vão além do binômio espaço-tempo. Se concentram também no aspecto da extensão do corpus de análise. (Cf. Ibid., p. 4-5)

Sobre a questão da terminologia, ele justifica a importância da mesma dizendo: "Diferentes eruditos ou escritores usam diferentes nomes para os mesmos componentes, o que pode levar a um grande grau de confusão, mesmo que um escritor particular possa usar tais termos consistentemente". ${ }^{114}$ (Ibid., p. 11) Mas a importância da terminologia vai além da nomenclatura e,

\footnotetext{
${ }^{112}$ Watson faz a distinção entre estudos linguísticos e literários baseado em H. G. Widdowson. É da definição dele de 'estilo' que Watson se apropria para apresentar seu objetivo: o estilo do verso hebraico. (Cf. Watson, 1984, p. 3)

113 "For a fuller understanding of the poetic techniques used in classical Hebrew poetry some comparison will be made [...]."

114 "Different scholars or writers use different names for the same components, which can lead to a great deal of confusion, even though a particular writer may use terms consistently."
} 
segundo ele "em definindo meus termos eu implico uma teoria subjacente relacionada à estrutura nos textos poéticos". ${ }^{115}$ (lbid.)

Ao expor sua metodologia de análise da PHB, Watson é cuidadoso em afirmar: "Nenhum único método uniforme de análise aplicável a todo poema pode, de fato, ser proposto. [...] Em última instância, é claro, o poema é uma entidade individual que não pode ser encaixada em uma camisa de força de classificação rígida". ${ }^{116}$ (Ibid., p. 16) Ainda assim, uma série de 14 passos ${ }^{117}$ que vão da seleção do poema até a comparação com outras literaturas é sugerida.

O método de Watson começa com a seleção da passagem poética a ser estudada. Ele sugere que o iniciante na prática escolha textos menores e mais facilmente identificáveis, como um salmo. (Cf. Ibid., p. 16) Depois deve-se ler os comentários disponíveis sobre o texto selecionado de forma a vislumbrar o que já foi dito sobre o mesmo. O passo seguinte é traduzir o poema de maneira a encontrar as dificuldades filológicas e textuais. (Cf. Ibid., p. 17)

Na sequência, Watson pondera sobre o Texto Massorético (TM) e, apesar de sugerir que possa haver necessidade de reconstrução do texto, ${ }^{118}$ conclui que "como regra geral é melhor deixar o texto sozinho e não começar a emendá-lo". ${ }^{119}$ (Ibid., p. 17) A leitura do poema, para "senti-lo", perceber sons e repetições e até o uso de canetas marcadoras para sublinhar palavras-chave, padrões de gênero e vocabulário fazem parte do método de se aproximar do poema de Watson. (Cf. Ibid., p. 17-18)

Esses passos, considerados preliminares por Watson, terminam com a escolha da aproximação que deverá ser feita do poema. A seguir, o poema precisa ser delimitado (início e fim), o que ocorre pela presença de indicadores

\footnotetext{
115 "[...] in defining my terms I imply an underlying theory concerning structure in poetic texts $[\ldots] . "$

"No single, uniform method of analysis applicable to every poem can, in fact, be proposed. [...] Ultimately, of course, the poem is an individual entity which cannot be fitted into the straightjacket of rigid classification."

117 Os catorze passos do método são: seleção, comentários, tradução, níveis do TM, leitura do poema, praticidades, aproximação, delimitação, segmentação, análise da estrofe, isolamento de artifícios poéticos, tabulação, síntese e comparação. (Cf. Watson, 1984, p. 16-20)

${ }^{118}$ Nesse quesito, Watson parece seguir a mesma linha de Geller e O'Connor ao questionar o TM.

119 "[...] as a general rule it is better to leave the text alone and not begin emending."
} 
de abertura e fechamento, como as chamadas 'formas pausais'. ${ }^{120}$ (Cf. Ibid., p. 18-19)

O próximo passo é dividir o poema em seus componentes. Watson relaciona essa segmentação a esticometria, cuja "principal guia" seria o paralelismo. Uma vez que os limites de cada estrofe (o verso) ${ }^{121}$ estão estabelecidos pela segmentação, deve-se analisar a estrofe, ou seja, entender o tipo de paralelismo, de padrões sonoros e de estrutura ali presentes. (Cf. Ibid., p. 19)

O décimo primeiro passo do método proposto por Watson é isolar os elementos poéticos, tais como pares de palavras, metáforas, elipses, etc. Feito isso, ele propõe que se faça uma tabulação de todas as palavras repetidas, das consoantes aliteradas, pares de palavras, etc. Essa tabulação, segundo Watson, ajudaria na percepção de elementos poéticos além da estrofe, como, por exemplo, o refrão. (Cf. Ibid., p. 19-20)

A síntese, penúltimo passo, consiste em determinar como os diversos elementos poéticos encontrados e analisados no nível da estrofe se relacionam ao longo do poema. Por fim, Watson recomenda a comparação do poema com literaturas semelhantes e indica que isso deveria ser feito seguindo a mesma forma literária - um lamento hebraico com um lamento sumério. (Cf. Ibid., p. 20)

Dentro dessa metodologia proposta por Watson, o paralelismo parece ter um status paradoxal. Ao passo que afirma que "paralelismo [...] pertence a um grupo maior de analogia matemática e não pode ser exaltado ao posto de 'a característica da poesia hebraica"122 (Ibid., p. 118), posteriormente o menciona como algo fundamental na PHB. (Cf. Watson, 1994, p. 16)

\footnotetext{
${ }^{120}$ Revell, em um artigo de 1981, apresenta a discussão do assunto. Sua tese é de que os versos já apresentam as formas pausais dividindo a linha do verso. Essa formas pausais (silluq, 'ole we-yored, 'athah, etc.) já apontariam as divisões dos versos. (Cf. Revell, 1981, p. 187) Ainda segundo Revell, nos versos menores, tanto os estudiosos medievais como os modernos concordam com a posição dessas formas pausais, mas em versos maiores, a discussão é que os leitores antigos viam o verso dividido em apenas duas linhas, enquanto os modernos chegam a vê-lo dividido em quatro. (Cf. Ibid., p. 189)

${ }_{121}$ Uma estrofe corresponde a uma unidade de verso - quer seja bicólon, tricólon ou monocólon. (Cf. Watson, 1984, p. 13)

${ }_{122}$ "Parallelism, it is now evident, belongs within a larger group of mathematical analogues and cannot be exalted to the rank of 'the characteristic of Hebrew poetry' [...]."
} 
Valorizando ou não o papel do paralelismo na PHB, Watson também critica a classificação de Lowth dos tipos de paralelismo, considerando-a incompleta e imprecisa (Cf. Ibid., p. 16) e nomeia uma extensa tipologia do fenômeno, por entender que "forma não pode ser dissociada do conteúdo, [...] e apreciação da técnica poética pode prover pistas cruciais para a correta interpretação das passagens em verso". ${ }^{123}$ (Ibid., p. 18)

A abordagem de Watson do paralelismo é totalmente distinta e se aproxima do fenômeno como um conceito matemático: "Falar de paralelismo é usar uma analogia baseada em conceitos matemáticos (ou, melhor, geométricos), e eruditos falharam em ver as profundas implicações resultantes desta noção comumente aceita". ${ }^{124}$ (Watson, 1984, p. 114)

Primeiro Watson expõe o que considera um equívoco dos estudiosos de poesia, a saber, o ato de olhar um poema. ${ }^{125}$ Esse ato corriqueiro demonstra a predisposição de entender o discurso (que envolve o tempo e sua passagem) no espaço (a página). Quer dizer, o poema não deveria ser entendido apenas na sua diagramação na página, se também envolve o tempo, mas também em seu próprio conceito de disposição espacial. (Cf. Ibid., p. 115)

Com essa discussão introdutória, Watson apresenta uma série de ilustrações baseadas no conceito de simetria geométrica. Essas ilustrações consistem de um ou mais gatos em frente de um espelho e suas respectivas imagens projetadas. A primeira delas segue abaixo (Cf. Ibid., p. 116):

\footnotetext{
123 "Form cannot be dissociated from content, [...] and appreciation of poetic technique can provide crucial clues to the correct interpretation of passages in verse."

124 "To talk about parallelism is to use an analogy based on mathematical (or, rather, geometrical) concepts and scholars have failed to see the deeper implications resulting from this commonly accepted notion."

${ }^{125} \mathrm{Em}$ uma nota de rodapé, Watson cita Daniel Rancour-Laferriére, que em seu livro sobre teoria poética de 1978 discute a relação entre o poema e o espaço.
} 


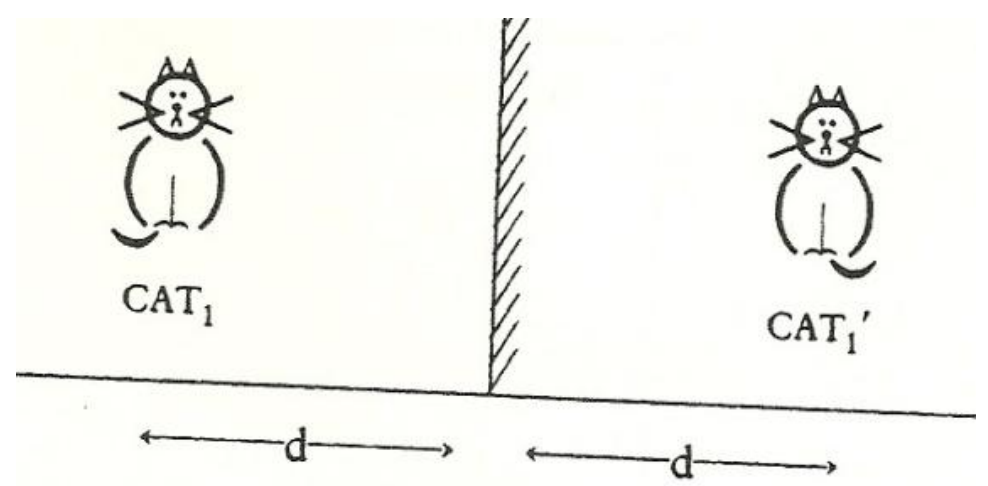

O reflexo do gato no espelho é equidistante e está no mesmo plano do próprio gato, mas está invertida. Watson pretende chamar a atenção para a questão da simetria, ou balanço, entre os 'dois' gatos, já que eles só podem ser considerados assim juntos, como um conjunto. Sua aplicação é que "simetria é uma relacionamento". ${ }^{126}$ (Ibid., p. 116)

Ele prossegue colocando dois gatos em frente ao espelho e que, obviamente, se tornam quatro (Cf. Ibid., p. 116):

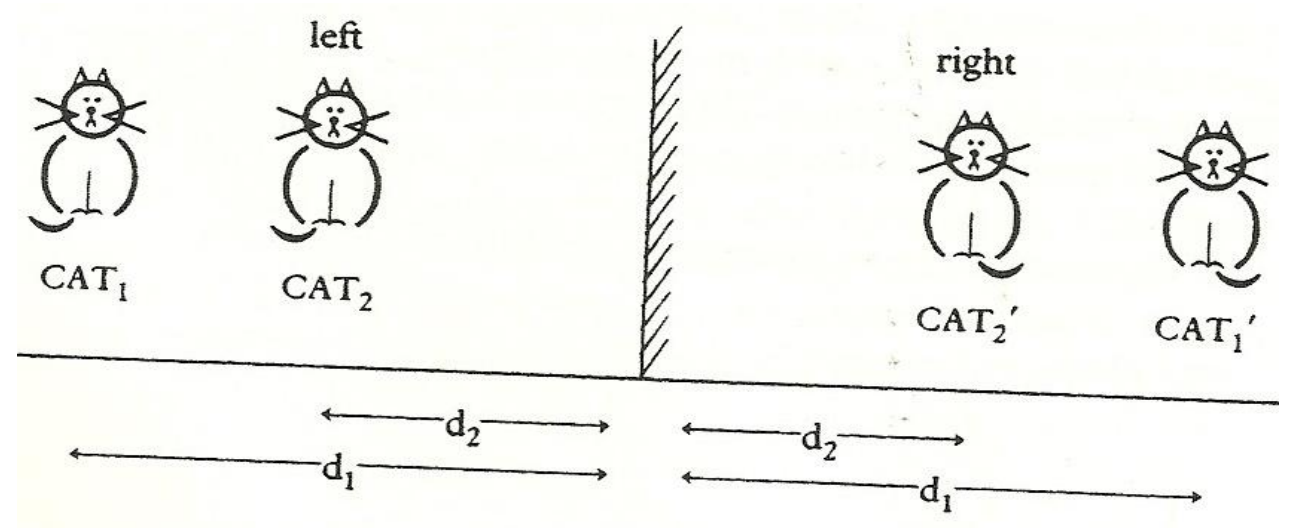

Watson pretende demonstrar as possibilidades que 0 conceito geométrico de paralelos pode conter, alterando-se a sequência (a ordem dos gatos), invertendo-se os sinais (a direção das caudas), etc. (Cf. Ibid., p. 116117)

Baseado nessa ilustração, ele relata quatro exemplos das possibilidades, são eles (Cf. Ibid., p. 118-119):

$\overline{126}$ "[...] symmetry is a relationship." 
1) Paralelismo (mesma sequência, mesmo sinal) - Jr $51: 27$

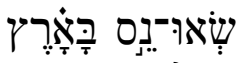

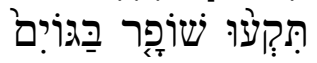

Estabeleça um estandarte na terra;

Tocai um šôpār entre as nações. ${ }^{127}$

2) Quiasmo, ${ }^{128}$ ou congruência reflexiva (sequência oposta, mesmo sinal) - SI 107:16

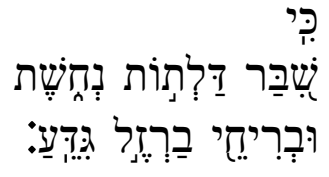

Pois

despedaçou as portas de bronze;

e as barras de ferro cortou em duas. ${ }^{129}$

3) Anticongruência (mesma sequência, sinal oposto) - SI 85:12 $12^{130}$

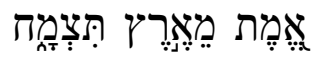

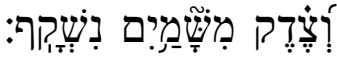

Verdade da terra brotará;

e justiça dos céus olhará para baixo. ${ }^{131}$

4) Anticongruência reflexiva, ou quiasmática (sequência oposta, sinal oposto) - SI 37:30

A boca do justo profere sabedoria;

\footnotetext{
${ }^{127}$ A divisão em versos segue a sugestão de Watson. (1984, p. 118) Sua tradução do hebraico foi: "Raise a standard in the land; / blow a trumpet among the nations."

${ }^{128}$ Devido à relevância desse tipo de paralelismo, ele será tratado em outro momento.

${ }^{129}$ A divisão em versos segue a sugestão de Watson. (1984, p. 118) Sua tradução do hebraico foi: "For / he has shattered doors of bronze; / and bars of iron he has snapped."

${ }_{130}^{130} \mathrm{Na}$ ARA, SI 85:11.

${ }^{131}$ A divisão em versos segue a sugestão de Watson. (1984, p. 118) Sua tradução do hebraico foi: "Fidelity from the earth will spring up; / and justice form the sky will peer down."
} 
e sua língua fala justiça. ${ }^{132}$

Essas quatro possibilidades seriam os principais tipos de relacionamento paralelístico. Variantes externas não afetam ou mudam a tipologia básica. Padrões parciais e subgrupos podem ocorrer dentro de cada um dos quatro tipos básicos. (Cf. Ibid., p. 119) E, apesar de citar com certa distinção a descrição de paralelismo de Kugel (Cf. Ibid., p. 120-121), Watson introduz uma série de variações dentro da classificação primária dada por ele. (Cf. Ibid., p. $123-159)^{133}$

O primeiro desses subgrupos é o do paralelismo de gênero, que pode se configurar com uma série de variações e para diferentes funções. (Cf. Ibid., p. 123-128) Esse tipo de paralelismo, segundo Watson, foi primeiro identificado na poesia ugarítica por Cassuto. (Cf. Watson, 1980, p. 322-323) O paralelo é geralmente entre os substantivos que podem ficar dispostos de diversas formas nas duas linhas do bicólon. Por exemplo, em SI 85:12 ${ }^{134}$ (Cf. Ibid., p. 324):

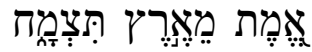

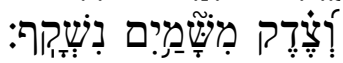

Verdade da terra brotará;

e justiça dos céus olhará para baixo.

Nesse caso, na primeira linha os dois substantivos são femininos (קֶֶ,

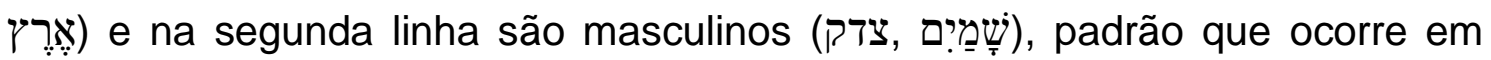
menor quantidade do que o contrário, ou seja, substantivos masculinos na primeira linha e femininos na segunda, como em Is 3:24 (Cf. Ibid., p. 324):

\footnotetext{
132 A divisão em versos segue a sugestão de Watson. (1984, p. 119) Sua tradução do hebraico foi: "The just man's mouth mutters wisdom; / his tongue speaks justice."

${ }^{133}$ Essa citação favorável de Kugel por Watson parece ignorar o fato de que Kugel discorda fortemente da ampla classificação do paralelismo, algo que Watson passa a fazer nos tópicos seguintes.

${ }^{134} \mathrm{Na}$ ARA, SI 85:11.
} 
e será

em lugar de perfume, decomposição acontecerá;

e em lugar de cinto, corda. ${ }^{135}$

O paralelismo de gênero também se dá com a inversão do padrão, ou seja, quando na primeira linha há dois substantivos, um masculino e um feminino, o que também ocorre na segunda linha, como em Is 41:2 (Cf. Watson, 1984, p. 124):

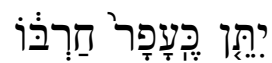

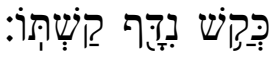

Ele os torna como poeira com sua espada; como restolho disperso com seu arco. ${ }^{136}$

No exemplo acima, a primeira linha apresenta um substantivo masculino (עפר) seguido de um feminino (חרב) e a segunda linha, na mesma sequência, um substantivo masculino (קש) e um feminino (קשת), sendo que a sequência inversa também pode suceder. (Cf. Ibid., p. 124)

Paralelismo de gênero também se dispõe em quiasmos, como em SI 37:30 (Cf. Ibid.):

A boca do justo profere sabedoria;

e sua língua fala justiça.

Aqui, na primeira linha temos a sequência de substantivo masculino (צכדיק) e feminino (חכמה), mas na segunda linha a ordem é invertida, com substantivo feminino (לשוֹן) primeiro, seguido de substantivo masculino (משפת)).

\footnotetext{
${ }^{135}$ A divisão em versos segue a sugestão de Watson. (1980, p. 324) Sua tradução do hebraico foi: "Instead of perfume, putrefaction there'll be, / instead of a belt, bonds."

${ }^{136}$ A divisão em versos segue a sugestão de Watson. (1984, p. 124) Sua tradução do hebraico foi: "Who makes them like dust with his sword, / like chaff, drives them with his bow?" Nós seguimos a tradução proposta por John Joseph Owens. (Cf. Owens, 1989, vol. 4, p. 124)
} 
Watson também lista o paralelismo de pares de palavras, ${ }^{137}$ citando 0 texto de Pv 26:1, onde neve e chuva se balanceiam e seriam um par de palavras de conteúdo sinônimo. (Cf. Ibid., p. 128):

Como neve no verão;

e como chuva na colheita ${ }^{138}$

Outro tipo de paralelismo exemplificado por Watson é o de número. Esse tipo seria uma variante do paralelismo de 'pares de palavras' e, visto que nenhum possui um sinônimo, a única maneira de prover uma relação paralela é acrescentar um número maior em valor na segunda linha. Normalmente esse número maior é o dígito imediatamente posterior ao colocado na primeira linha, como em Mq 5:4 ${ }^{139}$ (Cf. lbid., p. 144):

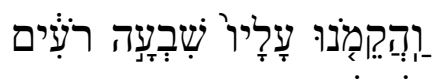

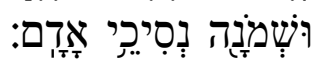

e faremos levantar contra ele sete pastores e oito príncipes dos homens ${ }^{140}$

Watson até introduz uma fórmula do paralelismo de número: ' $n / / n+1$ '. Mas é possível encontrar variações dessa fórmula, incluindo multiplicação (por onze, dez e cem). A fórmula e suas variações também são comuns na literatura acadiana e na ugarítica. (Cf. Ibid., p. 144-147; Roth, 1962, p. 300-302)

O paralelismo escada, como o nome indica, é aquele aonde há um processo de avanço em degraus. (Cf. Ibid., p. 150) Esse tipo é comum na literatura ugarítica e, na $\mathrm{BH}$, não fica restrito somente à poesia, aparecendo na prosa também. Parece ser um recurso comum quando no discurso direto. (Cf. Watson, 1983, p. 510-511)

\footnotetext{
${ }_{137}^{137}$ A terminologia 'pares de palavras' receberá tratamento específico adiante.

${ }^{138}$ A divisão em versos segue a sugestão de Watson. (1984, p. 128). Sua tradução do hebraico foi: "Like snow in summer, / and like rain at harvest."

${ }^{139} \mathrm{Na}$ ARA, Mq 5:5.

140 A divisão em versos segue a sugestão de Watson. (1984, p. 144) Sua tradução do hebraico foi: "then we will raise against him seven shepherds, / eight chiefs of men."
} 
O recurso do paralelismo escada pode ser usado com uma repetição da fraseologia da primeira linha, como em SI 77:17 ${ }^{141}$ (Cf. Watson, 1984, p. 151):

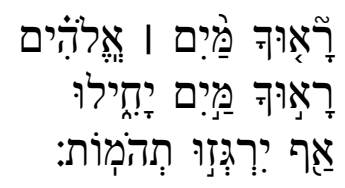

Viram -te as águas, Deus viram-te as águas, tiverem medo ; também perturbaram-se as profundezas. ${ }^{142}$

Mas também pode ser usado com a elipse de algum componente, tal qual Jz 5:7 com a preposição (Cf. Ibid., p. 152-153):

Até que se levantou Débora;

se levantou uma mãe em Israel. ${ }^{143}$

Outro exemplo de paralelismo escada com variação é Ct 6:1. Nesse verso não há a repetição das mesmas palavras, mas da mesma fraseologia com o uso de sinônimos (Cf. Ibid. p. 153):

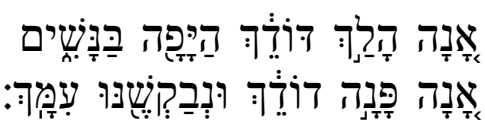

Para onde foi seu amado, mais bela entre as mulheres; para aonde se dirigiu seu amado e o procuraremos consigo. ${ }^{144}$

Por fim, Watson enumera de forma breve uma série de quatro tipos de paralelismo: sequência de sinônimos, não-verbal, vertical e janus. ${ }^{145} \mathrm{O}$

\footnotetext{
${ }^{141} \mathrm{Na}$ ARA, SI 77:16.

${ }^{142}$ A divisão em versos segue a sugestão de Watson. (1984, p. 151) Sua tradução do hebraico foi: "When the waters saw you, God, / when the waters saw you they trembled, / even the deeps shook in fear."

${ }^{143}$ A divisão em versos segue a sugestão de Watson. (1984, p. 153) Sua tradução do hebraico foi: "Until you arose, Deborah, / (until) you arose as a mother in Israel."

${ }^{144}$ A divisão em versos segue a sugestão de Watson. (1984, p. 153) Sua tradução do hebraico foi: "Whither has gone your love, O fairest among women, / Whither has turned your love, that we may look for him with you?."

${ }_{145}$ Jogo de palavras envolvendo polissemia, também chamado de paralelismo polissêmico. Quem primeiro fez uso do termo Janus foi Cyrus Gordon, em 1978. (Cf. Noegel, 1996, p. 11 -
} 
paralelismo de sequência de sinônimos pode ser exemplificado em SI 135:5 (Cf. lbid. p., 157):

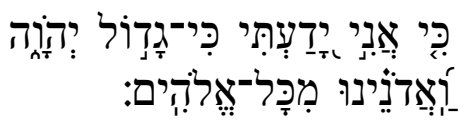

Pois eu sei que grande é YHWH;

e nosso Senhor sobre todos os deuses.

Posteriormente Watson vai denominar esse tipo de paralelismo de paralelismo de grande precisão dizendo: "a linha $B$ especifica a linha $A$ de alguma maneira [...]. Nesses casos o poeta não está meramente repetindo em palavras diferentes, mas corrigindo seu foco". ${ }^{146}$ (Watson, 1994, p.16)

O paralelismo não-verbal é quando um verbo serve de paralelo para um substantivo ou correlato. ${ }^{147}$ Jó 18:21 ilustra bem esse tipo. (Cf. Watson, 1984, p. 157):

Certamente essas são as moradas do pecador; e esse é o lugar do que não conhece a Deus.

Quanto ao paralelismo vertical, ${ }^{148}$ Watson o define como se estendendo além do par de linhas e com paralelos, como diz o nome, verticais e não horizontais. (Cf. Ibid., p. 158) Ele pode ser reconhecido no texto de Pv 3:6 (Cf. Tsumura, 2009, p. 175):

Em todos os teus caminhos reconhece-o;

12) 'Janus' é uma referência a mitologia romana, já que o deus das portas, passagens e pontes era representado com duas faces voltadas para lados opostos.

146 "[...] the B-line specifies the A-line in some way [...]. In such cases the poet is not merely repeating himself in different words but correcting his focus."

${ }^{147}$ Aqui Watson dá total crédito a Daniel Grossberg como o 'descobridor' desse tipo e apresenta a argumentação resumida dele. (Cf. Watson, 1993, p. 157-158)

${ }^{148}$ A nomenclatura de Watson é utilizada por Tsumura, que amplia e desenvolve a ideia relacionando-a aos escritos de Jakobson. (Cf. Tsumura, 2009, p. 167-181) 
e ele endireitará tuas veredas. ${ }^{149}$

No exemplo acima, a segunda linha depende verticalmente da primeira, gramaticalmente falando. Ou seja, há uma sentença expressa em duas linhas. E o par de palavras caminhos (דרכים) e veredas (ארחות) reforçam a ligação e o paralelo entre as linhas. (Ibid.)

Por fim, Watson conclui com o paralelismo Janus, ou polissêmico, que também é ferramenta utilizada na literatura ugarítica (Cf. Ibid., p. 159) Um dos primeiros exemplos a ser descoberto foi o do texto de Ct 2:12. (Cf. Noegel, 1996, p. 12):

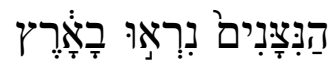

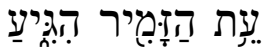

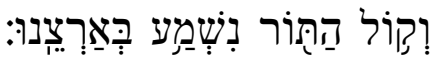

As flores apareceram na terra,

o tempo de זמיר chegou,

e a voz da pomba é ouvida na nossa terra. ${ }^{150}$

A palavra זמיר, que possui dois significados distintos - 'cântico'/'música' e 'poda' (cf. Koehler e Baumgartner, 2001, p. 273-274), pode ser conectada das duas formas no tricólon. Se for traduzida como cântico/música se liga à última linha (a voz da pomba ouvida na terra) e como poda se liga à primeira (as flores na terra). A ideia é justamente que haja uma leitura polissêmica da palavra. (Cf. Noegel, 1996, p. 12)

Esse recurso, o paralelismo Janus, aparece notadamente outras duas vezes no texto de Cântico dos Cânticos, primeiro em Ct 7:5-6 ${ }^{151}$ (Cf. Ibid., p. 33):

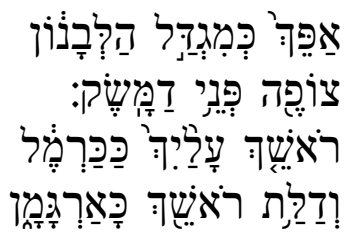

\footnotetext{
149 A divisão em versos segue a sugestão de Tsumura. (2009, p. 175) Sua tradução do hebraico foi: "In all your ways acknowledge him, / who makes straight your paths."

${ }^{150}$ A divisão em versos segue a sugestão de Noegel. (1996, p. 12) Sua tradução do hebraico foi: "The blossoms have appeared in the land; / the time of זמיר has arrived, / the call of the turtledove is heard in our land."

${ }^{151} \mathrm{Na}$ ARA, Ct 7:4-5.
} 
Teu nariz como torre do Líbano, olhando por sobre a face de Damasco, כרמל sobre ti como ראשך e tua cabeleira solta como púrpura. ${ }^{152}$

Na terceira linha duas palavras podem ter dois significados cada: ראשך pode significar tanto 'tua cabeça' quanto 'teu cume'; e כרמל pode ser 'carmesim' ou 'Carmelo'. Se a sugestão for seguir com 'tua cabeça' e 'carmesim' essa linha fará paralelo com a seguinte ('cabeleira' e 'púrpura'), mas se a escolha for 'cume' e 'Carmelo', o paralelo é com as duas linhas anteriores ('torre do Líbano', 'face de Damasco'). Ou seja, há a busca pela polissemia novamente. (Cf. Ibid.)

O outro paralelismo Janus de Cântico dos Cânticos está em Ct 7:12$13^{153}$ (Cf. Ibid.):

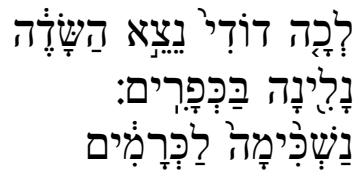

Vem meu amado, saiamos aos campos, passemos a noite na/entre כפרים sigamos cedo para os vinhedos. ${ }^{154}$

A expressão בכפרים pode ser lida como 'nas vilas' e assim faria o paralelo com a linha anterior ('campos'). Mas também pode ser 'entre henas', fazendo paralelo com a linha posterior ('vinhedos'). Novamente, a construção Janus indicaria a dupla possibilidade. (Cf. Ibid., p. 34)

\subsubsection{MeIr WeISS E Robert ALter: A BUSCA POR Simplicidade}

\footnotetext{
152 A divisão em versos segue a sugestão de Noegel. (1996, p. 33) Sua tradução do hebraico foi: "Your nose is as the tower of Lebanon / which faces the face of Damascus. / כראש / upon you is as כרמל / and the coiffure of your head is as purple."

${ }_{153}^{153} \mathrm{Na}$ ARA, Ct 7:11-12.

154 A divisão em versos segue a sugestão de Noegel. (1996, p. 34) Sua tradução do hebraico foi: "Come my beloved, let us go to the field; / let us lodge in/among the כפרים / Let us rise up early to the vineyards."
} 
Do mesmo ano do manual de Watson, The Bible from Within (1984), de Meir Weiss, indica um novo método para o estudo da BH. Chamado de 'Método da Interpretação Total', aplicado por Weiss, principalmente, a textos poéticos. A tese fundamental de Weiss é: "O 'poético' é manifesto na forma; conteúdo existe somente na medida em que é revelado em sua forma [...]". ${ }^{155}$ (Weiss, p. 272) Ou seja, Weiss defende a indissociabilidade entre a forma e o conteúdo para análise de PHB. (Cf. Ibid., p. 46)

Weiss chama a atenção dos intelectuais estudiosos da Bíblia para a riqueza e diversidade do paralelismo, para ele "o mais característico elemento estilístico da poesia bíblica." ${ }^{156} \mathrm{Em}$ sua opinião, a tentativa de padronizar o paralelismo, codificando suas formas de acordo com algum esquema, é uma falha de compreensão do fenômeno. (Cf. Ibid., p. 244)

Robert Alter também discorre sobre paralelismo buscando enfatizar sua dinâmica para além de definições e/ou classificações. Falando especificamente do paralelismo sinônimo, ele aponta que a ideia em si assume um grau considerável de estatismo (cf. Alter, 1985, p. 10), além de afirmar que "nenhuma língua possui sinônimos inteiramente verdadeiros."157 (Ibid., p. 13)

Alter ecoa Kugel ao afirmar: "O maior obstáculo na abordagem da poesia bíblica tem sido a concepção errônea de que paralelismo implica sinonímia, ou seja, dizer o mesmo duas vezes com palavras diferentes". (Alter, 1997, p. 658) Entretanto, diferentemente de Kugel, Alter acredita que o paralelismo semântico (e até sintático) exista e seja uma característica prevalecente do versículo bíblico. Ele, inclusive, compara o uso do paralelismo com o do pentâmetro iâmbico no verso de Shakespeare, ou seja, como sendo um modelo formal da PHB. (Cf. Ibid., p. 655)

Fugindo da imposição de categorias, Alter procura enfatizar o que considera o marco do paralelismo bíblico:

\footnotetext{
155 "The 'poetic' is manifest in the form; content exists only insofar as it is revealed in the form $[\ldots \ldots] . "$ "[...] the most characteristic stylistic feature of Biblical poetry [...]."

157 "[...] no language has entirely true synonyms [...]."
} 
O padrão dominante é um foco, intensificação ou especificação de idéias (sic), imagens, ações, temas de um verseto para o seguinte. Se algo é quebrado no primeiro verseto, é despedaçado ou estilhaçado no segundo; se uma cidade é destruída no primeiro verseto, ela é transformada em um monte de entulho no segundo. Um termo geral na primeira metade da linha é seguido, de modo típico, por uma instância específica da categoria geral na segunda metade; ou, novamente, uma afirmação literal no primeiro verseto torna-se uma metáfora ou hipérbole no segundo. (Ibid., p. 648)

Como exemplo desse conceito de intensificação, Alter apresenta uma série de exemplos, entre os quais, SI 88:12-13 ${ }^{158}$ (cf. Alter, 1985, p. 14):

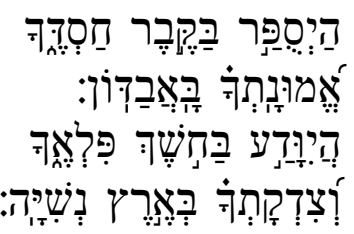

É declarado na cova o Teu favor,

Tua fidelidade em 'ăbaddôn?

São conhecidas na escuridão Tuas maravilhas, e Tua justiça na terra do esquecimento? ${ }^{159}$

No texto, 'favor', 'fidelidade', 'maravilhas' e 'justiça' aparecem como termos típicos de balanço entre as linhas, comportando-se como conceitos complementares conectados. Ao mesmo tempo, 'cova', "ăbaaddôn', ${ }^{160}$ 'escuridão' e 'esquecimento' aparecem em uma progressão de imagens relativas à morte. Da palavra corriqueira 'cova', para a quase-mítica 'ăbaddôn' há uma intensificação e uma especificação. Na sequência do texto, uma palavra corriqueira e concreta, 'escuridão', é paralela à expressão 'terra do esquecimento', de conotação sensorial. Ou seja, a obviedade da relação entre cova e morte é ampliada e intensificada linha após linha, tornando o texto dinâmico e não repetitivo. (Cf. Ibid.)

\footnotetext{
${ }^{158} \mathrm{Na}$ ARA, SI 88:11-12.

${ }^{159}$ A divisão em versos segue a sugestão de Alter. (1985, p. 14) Sua tradução do hebraico foi: "Will Your steadfast care be told in the grave, / Your constancy in Perdition? // Will Your wonders be known in the darkness, / Your bounty in the land of oblivion?". A tradução sugerida por mim procura manter a ordem das palavras do texto Massorético.

160 Alter traduz אִבַּדוֹ como "Perdição". (1985, p. 14) Koehler e Baumgartner a traduzem por "lugar de destruição", "submundo" e a coloca em paralelo com שִׁị (2001, p. 3) e por isso preferi deixá-la sem tradução.
} 
O que Alter procura ressaltar, portanto, é que no paralelismo há sempre algo novo sendo acrescentado à primeira afirmação, e não apenas novo, mas mais intenso. (Cf. Alter, 1997, p. 658; 1985, p. 84) Em outra semelhança com a argumentação de Kugel, ele afirma:

O que eu gostaria de propor, e essa é a única coisa a respeito da qual meu entendimento do fenômeno é parecido do de James Kugel, é que uma descrição diametralmente oposta do sistema - um argumento a favor do movimento dinâmico de um verso para o próximo - seria muito mais próxima da verdade, muito mais próxima da maneira pela qual os poetas bíblicos esperavam que as audiências prestassem atenção para suas palavras. ${ }^{161}$ (Alter, 1985, p. 10)

Em geral, as conclusões de Alter e Kugel se assemelham e presumem uma natureza de intensificação no paralelismo hebraico bíblico. (Cf. Roberts, 2001, p. 55) Nas palavras de Alter: "O que isso significa é que a poesia da Bíblia refere-se, acima de tudo, ao processo dinâmico que se move em direção a algum clímax". (Alter, 1997, p. 663)

\subsubsection{AdELE BERLIN: UMA APROXIMAÇÃo LINGUíSTICA}

Assim como James Kugel e Robert Alter, Adele Berlin considera que o paralelismo é um fenômeno linguístico complexo e reduzi-lo a uma mera repetição de um pensamento ou estrutura sintática com palavras diferentes é um equívoco. (Cf. Berlin, 1985, p. 129-130) Ela também tece críticas quanto ao legado de Lowth, que, segundo ela, manteve a visão do paralelismo bíblico estreita, limitada ao relacionamento entre as linhas. (Cf. Ibid., p. 3)

Entretanto, de uma outra perspectiva, Berlin considera a ideia de paralelismo de Kugel, "A, ainda mais B" nebulosa e despropositada enquanto definição. (Cf. Ibid., p. 130) Para ela, paralelismo consiste de "uma rede de

\footnotetext{
161 "What I should like to propose, and this is the one respect in which my own understanding of the phenomenon is close to James Kugel's, is that a diametrically opposite description of the system - namely, an argument for dynamic movement from one verset to the next - would be much closer to the truth, much closer to the way the biblical poets expected audiences to attend to their words."
} 
equivalências e/ou contrates envolvendo muitos aspectos e níveis da linguagem". ${ }^{162}$ (lbid., p. 141)

Tomando uma definição mais abrangente, baseada nos estudos linguísticos de Roman Jakobson, Berlin sugere que a busca pela "equivalência linguística" deve ir além de linhas e sentenças adjacentes e estender-se por todo o texto. (Cf. Ibid., p. 3) Ela demonstra, ao longo de seu livro The Dynamics of Biblical Parallelism, que o paralelismo ativa os quatro principais aspectos da linguagem: gramatical, lexical, fonológico e semântico; e ainda que esses aspectos podem ocorrer em combinação. (Cf. Ibid., p. 127)

O paralelismo gramatical pode ser de dois tipos, morfológico e sintático. O primeiro ocorre no nível das palavras e se dá quando uma é substituída por outra de função sintática semelhante. (Cf. Ibid., 31-53) Por exemplo, no SI 33:8 o substantivo da primeira linha dá lugar ao pronome na segunda linha (cf. Lucas, 2003, p. 70):

Tenham medo de YHWH toda a terra,

dEle permaneçam em temor todos os habitantes do mundo. ${ }^{163}$

Outro exemplo dado é Ct 3:1, onde o substantivo ou o pronome da primeira linha é substituído por uma cláusula relativa na segunda (cf. Berlin, 1985, p. 33):

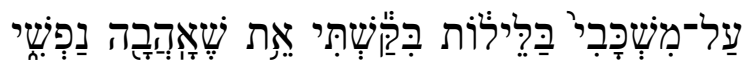

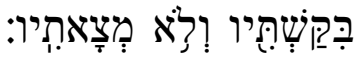

Sobre minha cama, à noite, eu busquei aquele a que minha alma ama;

eu busquei por ele, mas não o achei. ${ }^{164}$

\footnotetext{
162 "a network of equivalence and/or contrasts involving many aspects and levels of language."

${ }^{163}$ A divisão em versos segue a sugestão de Lucas. (2003, p. 70) Sua tradução do hebraico foi: "Let all the earth fear the Lord; / let all the inhabitants of the world stand in awe of Him."

${ }^{164}$ A divisão em versos segue a sugestão de Berlin. (1985, p. 33) Sua tradução do hebraico foi: "On my coach at night I sought the one I love; / I sought him but did not find him."
} 
Ainda no paralelismo gramatical, há o tipo sintático, quando a estrutura da sentença da segunda linha é transformada em relação à primeira (cf. Ibid., p. 53-63), como em SI 6:6 $6^{165}$, onde a primeira linha apresenta uma afirmação e a segunda uma pergunta (cf. Lucas, 2003, p. 71):

Pois não há na morte, lembrança de ti;

no šěôl quem louvará a ti? ${ }^{166}$

Outro tipo de paralelismo proposto por Berlin é o lexical, onde ela trabalha a questão dos "pares de palavras"167 extensivamente, apresentando regras sintagmáticas e paradigmáticas para o fenômeno. (Cf. Berlin, 1985, p. 64-80) Esses pares de palavras ocorrem em linhas subsequentes, como por exemplo, céus/terra em SI 115:16 (cf. Lucas, 2003, p. 71):

Os céus são céus de YHWH;

mas a terra Ele deu para os filhos do homem.

O paralelismo semântico, segundo Berlin, "é o relacionamento entre o significado de uma linha e sua linha paralela". ${ }^{168}$ (Berlin, 1985, p. 90) Ela foge das categorias de Lowth e da abrangência de Kugel (cf. Lucas, 2003, p. 71) e propõe a tese da equivalência, sem necessariamente significar semelhança ou antítese. (Cf. Berlin, 1985, p. 90) Sua exposição sobre esse tipo de paralelismo inclui o exemplo do SI 102:2 $2^{169}$ (cf. lbid., p. 94):

YHWH, escuta minha oração;

e meu clamor a Ti chegue. ${ }^{170}$

\footnotetext{
${ }^{165} \mathrm{Na}$ ARA, SI 6:5.

${ }^{166}$ A divisão em versos segue a sugestão de Berlin. (1985, p. 59) Sua tradução do hebraico foi: "For in Death there is no mention of you; / In Sheol who can acclaim you?."

${ }^{167} \mathrm{O}$ conceito de "par de palavras" será demonstrado posteriormente nesse trabalho.

168 "[...] is the relationship between the meaning of one line and its parallel line."

${ }^{169} \mathrm{Na}$ ARA, SI 102:1.

${ }^{170}$ A divisão em versos segue a sugestão de Berlin. (1985, p. 94) Sua tradução do hebraico foi: "YHWH, hear my prayer; / and let my cry reach you."
} 
Por fim, Berlin identifica o paralelismo fonológico que seria, basicamente, a presença de paronomásia. (Cf. Ibid., p. 103) Sua exposição vai lidar com "pares de sons" que ela define como: "a repetição em palavras ou linhas paralelas de consoantes iguais ou similares em qualquer ordem com iminente proximidade". (Ibid., p. 104) Um dos exemplos é SI 18:32 ${ }^{171}$ (cf. Ibid., p. 105):

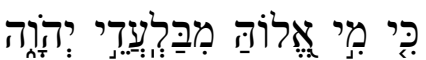

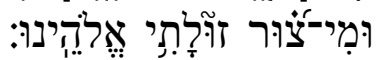

Pois quem é Deus a não ser YHWH?;

e quem é rocha se não nosso Deus? ${ }^{172}$

Sobre a variedade e complexidade do paralelismo, Berlin conclui:

Com tantos aspectos da linguagem capazes de serem ativados (pode haver mais do que quatro) e tantas possibilidades para tipos de equivalência ou contraste em cada, que poderia parecer que o número de possíveis paralelismos para cada linha dada é enorme - talvez infinito. ${ }^{173}$ (Berlin, 1985, p. 127)

Como exemplo dessa conclusão, Berlin lista onze textos com paralelismos do livro de Salmos contendo a ideia de que Deus escuta a oração do salmista. Os exemplos, organizados em três grupos, partem da menor para a maior complexidade. Segue o primeiro grupo de quatro salmos (cf. Berlin, 1985, p. 127-128):

1) $\mathrm{SI} 54: 4^{174}$

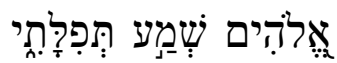

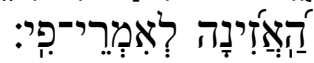

Deus, ouve minha oração;

Dê ouvidos para as palavras da minha boca. ${ }^{175}$

\footnotetext{
${ }_{172}^{171} \mathrm{Na}$ ARA, SI 18:31

172 A divisão em versos segue a sugestão de Berlin. (1985, p. 104) Sua tradução do hebraico foi: "For who is a god except YHWH; / And who is a rock besides our God?."

173 "With so many aspects of language capable of being activated (there may be more than four), and so many possibilities for types of equivalence or contrast in each, it would seem that the number of possible parallelisms for any given line is enormous - perhaps infinite."

${ }_{174} \mathrm{Na}$ ARA, SI 54:2

${ }^{175}$ A divisão em versos segue a sugestão de Berlin. (1985, p. 128) Sua tradução do hebraico foi: "God, hear my prayer; / Harken to the words of my mouth."
} 
2) SI 61:2 176

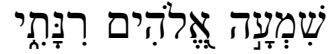

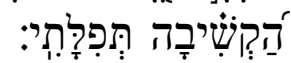

Ouve, Deus, meu clamor;

Escuta atentamente minha oração. ${ }^{177}$

3) SI 66:19

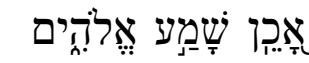

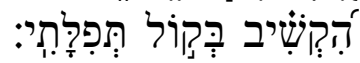

Verdadeiramente ouviu Deus

Escutou atentamente a voz da minha oração. ${ }^{178}$

4) SI 84:9179

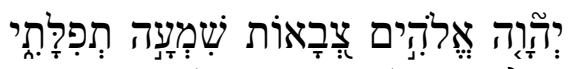

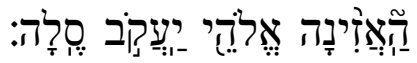

YHWH, Deus dos exércitos, ouça minha oração;

Dê ouvidos, Deus de Jacó, selāh. ${ }^{180}$

Nos quatro exemplos acima, a equivalência entre as linhas se dá: pela variação lexical (com o sujeito antes do verbo), como em SI 54:4 e pela elipse do sujeito em SI 54:4, 61:2 e 66:19; pela variação gramatical (frase preposicionada que torna o objeto do verbo indireto, ao invés de direto) como nos SI 54:4 e 66:19; pela variação da ordem das palavras (sujeito + verbo na primeira linhas, seguido de verbo + sujeito na segunda linha) como no SI 84:9. (Cf. Berlin, 1985, p. 128)

A equivalência também é notada pela escolha de verbos semanticamente semelhantes, que seguem a tendência apontada por Alter, do verbo mais ordinário na primeira linha para um mais literário na segunda. (Cf.

\footnotetext{
${ }_{176}^{176} \mathrm{Na}$ ARA, SI 61:1.

177 A divisão em versos segue a sugestão de Berlin. (1985, p. 128) Sua tradução do hebraico foi: "Hear, God, my song; / Harken [to] my prayer."

${ }^{178}$ A divisão em versos segue a sugestão de Berlin. (1985, p. 128) Sua tradução do hebraico foi: "Indeed God heard; / He harkened to the sound of my prayer."

${ }_{179}^{179} \mathrm{Na}$ ARA, SI 84:8.

${ }^{180}$ A divisão em versos segue a sugestão de Berlin. (1985, p. 128) Sua tradução do hebraico foi: " YHWH, the God of Hosts, hear my prayer; / Harken, God of Jacaob, Selah."
} 
Alter, 1985, p. 13-15) Entretanto, é curioso notar que no SI $61: 2$ essa tendência (ordinário-literário) se dê nos verbos ששב e שמע שמע, mas seja invertida nos

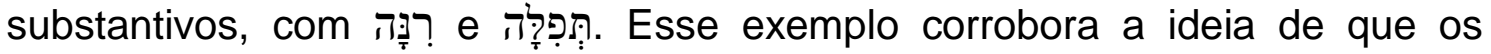
poetas bíblicos, por vezes, procurassem evitar a regularidade com pequenas variações. (Cf. Alter, 1997, p. 655)

Os próximos três salmos têm construção semelhante entre si (cf. Berlin, 1985, p. 128):

5) SI 102:2 $2^{181}$

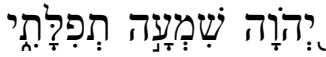

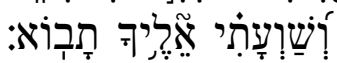

YHWH, ouve minha oração;

E meu pedido até ti chegue. ${ }^{182}$

6) $\mathrm{SI} 88: 3^{183}$

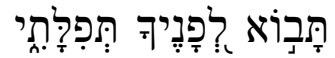

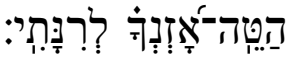

Que chegue diante da tua face minha oração; Inclina teu ouvido para meu clamor. ${ }^{184}$

7) SI $88: 14^{185}$

Mas eu, para ti, YHWH, peço;

E pela manhã, minha oração, levo diante de ti. ${ }^{186}$

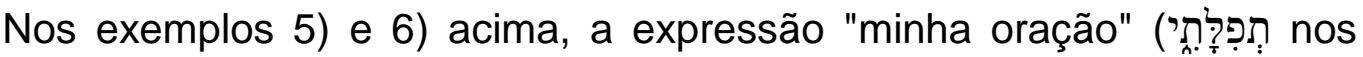

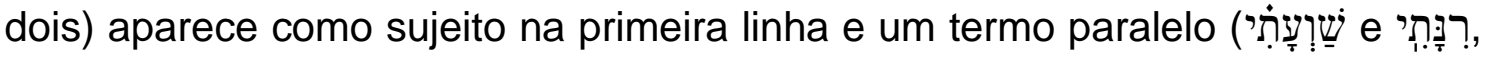
respectivamente) como objeto na linha seguinte, criando balanço e tensão,

\footnotetext{
${ }^{181} \mathrm{Na}$ ARA, SI 102:1.

182 A divisão em versos segue a sugestão de Berlin. (1985, p. 128) Sua tradução do hebraico foi: "YHWH, hear my prayer; / And may my cry come to you."

${ }_{183} \mathrm{Na}$ ARA, SI 88:2.

${ }^{184}$ A divisão em versos segue a sugestão de Berlin. $(1985$, p. 128) Sua tradução do hebraico foi: "May my prayer come before you; / Incline your ear to my song."

${ }^{185} \mathrm{Na}$ ARA, SI 88:13.

${ }^{186}$ A divisão em versos segue a sugestão de Berlin. (1985, p. 128) Sua tradução do hebraico foi: "As for me, to you, YHWH, I cry; / And at morning my prayer greets you."
} 
equivalência e contrate. Em SI 88:14, o fenômeno, um pouco mais complexo, é semelhante, já que o fraseado verbal, שִ diș da primeira linha, é paralelo à expressão nominal,

Os quatro últimos exemplos são (cf. Ibid., p. 129):

8) $\mathrm{SI} 4: 2^{187}$

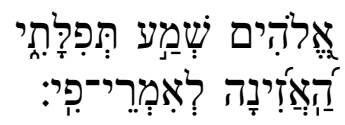

Deus, ouve minha oração;

Dê ouvidos para as palavras da minha boca. ${ }^{188}$

9) SI 71:2

Ouve, Deus, meu clamor;

Escuta atentamente minha oração. ${ }^{189}$

10) SI 119:149

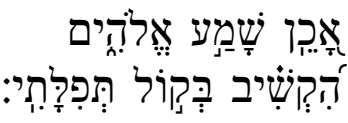

Verdadeiramente ouviu Deus

Escutou atentamente a voz da minha oração. ${ }^{190}$

11) SI 143:1

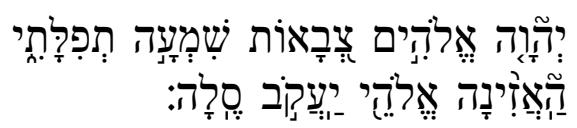

YHWH, Deus dos exércitos, ouça minha oração;

\footnotetext{
${ }_{187}^{187} \mathrm{Na}$ ARA, SI 4:1.

${ }^{188}$ A divisão em versos segue a sugestão de Berlin. (1985, p. 129) Sua tradução do hebraico foi: "When I call, answer me, my righteous God; / In dire straits you eased [things] for me; / Be gracious to me and hear my prayer."

${ }^{189}$ A divisão em versos segue a sugestão de Berlin. (1985, p. 129). Sua tradução do hebraico foi: "According to your righteousness save me and rescue me; / Incline your ear to me and deliver me."

${ }^{190}$ A divisão em versos segue a sugestão de Berlin. (1985, p. 129) Sua tradução do hebraico foi: "Hear my voice as befits your loyalty; / YHWH, as befits your justness preserve me."
} 
Dê ouvidos, Deus de Jacó, selāh. ${ }^{191}$

Esses quatro últimos versos, de maior complexidade, possuem um campo semântico maior, com mais possibilidades de paralelismo. Berlin aponta uma maior equivalência sintagmática nesse derradeiro grupo de exemplos - 0 pedido (para que a oração seja ouvida) não se "repete" (não há um paralelo direto), mas há uma ideia consequencial de equivalência - e, dada a variedade de possibilidades, sustenta que não se deveria reduzir a definição de paralelismo a uma ou outra forma. (Cf. Ibid., p. 129)

Ainda segundo Berlin, existem quatro princípios que auxiliam no reconhecimento de um paralelismo, tornando-o perceptível: "proximidade dos equivalentes linguísticos, similaridade das estruturas superficiais, o número dos equivalentes linguísticos envolvidos e a expectativa da equivalência". ${ }^{192}$ (Ibid., p. 131)

Ela ainda conclui que a percepção do paralelismo, embora importante, não é necessariamente o que vai trazer entendimento ao texto: "deixe-me fazer claro de uma vez que o paralelismo em si mesmo não tem significado". ${ }^{193}$ Entretanto, os elementos formais de um texto ajudam na estruturação do mesmo e produzem impacto em como a mensagem será alcançada. (Cf. Ibid., p. 135)

O resultado do estudo da dinâmica do paralelismo bíblico, para Berlin, é que:

Cada paralelismo é projetado para se adequar em seu próprio contexto, para tomar parte do significado do texto como um todo e contribuir para ele. Paralelismo em si mesmo não possui significado; mas estrutura o significado dos sinais para os quais foi composto. ${ }^{194}$ (lbid., p. 138)

\footnotetext{
${ }^{191}$ A divisão em versos segue a sugestão de Berlin. (1985, p. 129) Sua tradução do hebraico foi: "YHWH, hear my prayer; / Give ear to my pleadings in your steadfastness; / Answer me in your righteousness."

192 "[...] proximity of the linguistic equivalences, the similarity of their surface structures, the number of linguistic equivalences involved, and the expectation of equivalence."

193 "Let me make clear at once that parallelism in itself does not have meaning."

194 "Each parallelism is designed to fit into its own context, to partake of the meaning of the text as a whole and to contribute to it. Parallelism itself does not have meaning; but it structures the meaning of signs of which it is composed."
} 


\subsubsection{CONSIDERAÇÕES POSTERIORES: REAFIRMAÇÕES}

David Clines, também reconhece as amplas possibilidades do paralelismo e também critica a definição 'restritiva' de James Kugel. (Cf. Clines, 1987, p. 95) Com ideia semelhante a de Adele Berlin, declara:

Poesia bíblica em geral é grandemente composta de pares de linhas (ou três linhas, um par estendido), e desses pares de linhas podemos afirmar que são de um tipo (A está relacionado a B) ou de uma centena, mas não que são de três, ou quatro, ou cinco. ${ }^{195}$ (lbid.)

A citação acima, inclusive, parece remeter a uma passagem do próprio Kugel, quando ele critica as categorias de Lowth e propõe a sua, dizendo: "Paralelismo bíblico é de uma classe, 'A, e ainda mais $B$ ' ou de centenas de classes, mas não de três". ${ }^{196}$ (Kugel, 1981, p. 58)

A conclusão de Clines é que a relação entre o par de linhas é de tal intensidade e complexidade que "o todo é diferente da soma das partes, porque as partes influenciam ou contaminam uma a outra". ${ }^{197}$ (Clines, 1987, p. 95)

Luis Alonso Schökel também argumenta que o paralelismo, embora possa se estabelecer ao longo do texto, é preferencialmente entre duas linhas subsequentes. (Cf. Schökel, 2000, p. 49) Exemplificando, ele usa o SI 114:1-2 (cf. Ibid., p. 48):

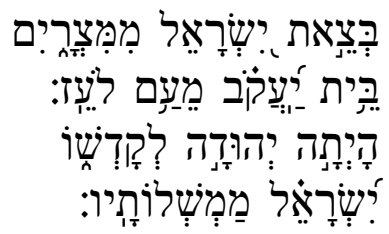

Quando saiu Israel do Egito, a casa de Jacó de um povo de fala ininteligível; tornou-se Judá por seu santuário,

\footnotetext{
195 "Biblical poetry in general is overwhelmingly composed of couplets (or triplets, extended couplets), and of such couplets we would state that they are of one sort ( $A$ is related to $B$ ) or of a hundred, but not of three or four or five."

196 "Biblical parallelism is of one sort, 'A, and what's more B', or hundred sorts; but it is not three."

197 "The whole is different from the sum of its parts because the parts influence or contaminate each other."
} 
Israel como seu domínio. ${ }^{198}$

Sobre o texto acima, Schökel diz: "Que maneira curiosa de se expressar! É como se, quando andando, alguém desse dois passos pra frente com a perna direita e depois dois com a perna esquerda." (Ibid., p. 48) Seu argumento é que a construção sintática normal seria posicionar a oração principal logo depois da subordinada, que deixaria o texto assim (cf. Ibid.):

Quando saiu Israel do Egito, tornou-se Judá por seu santuário;

a casa de Jacó de um povo de fala ininteligível, Israel como seu domínio.

Ao invés disso, o salmista dobra a primeira sentença antes de prosseguir, fazendo com que ambas soem e ressoem. O uso do artifício cria uma interrupção, um suspense, uma tensão. (Cf. Ibid.) O paralelismo nas duas primeiras linhas afeta somente a primeira linha, criando especificidade e trazendo à tona um contexto histórico, e protela o desfecho da sentença. Já o segundo paralelismo, nas duas linhas seguintes, afeta ambos os versos e acrescenta intensidade à declaração da primeira linha do verso dois, "tornou-se Judá por seu santuário". (Ibid., p. 49)

Sobre a natureza do paralelismo, Schökel postula:

O uso do termo 'paralelismo' é metafórico. Seu significado apropriado se refere ao espaço, mas a poética o aplica a um processo no qual é mais ligado ao tempo do que ao espaço. É preferível falar de 'ritmo' de quadros dípticos. ${ }^{199}$ (Ibid., p. 50)

Seu argumento é de que o paralelismo é a operação mais básica da linguagem na reconstrução da pluralidade da realidade circundante. A raiz do paralelismo seria não somente a história ou o processo literário, mas a linguagem em si, já que ela procura articular, através do som, sintaxe, ritmo e semântica, essa pluralidade. (Cf. Ibid., p. 51)

\footnotetext{
198 Fokkelman apresenta a tradução do texto de acordo com a RSV (Revised Standard Version): "If I forget you, O Jerusalem, / let my right hand whither; / let my tongue cleave to the roof of my mouth, / if I do not remember you, / if I do not set Jerusalem / above my highest joy."

199 "The use of the term 'parallelism' is metaphorical. Its proper meaning refers to space, but poetics applies it ot a process which is linked more to time than space. It is rather like speaking of th 'rythm' of a diptych of paintings."
} 
S. E. Gillingham inicia seu livro declarando dívida com os escritos de Schökel, Watson e Alter (cf. Gillingham, 1994, p. vii) e, de fato, seu primeiro exemplo usado para descrever o paralelismo é o mesmo de Schökel, SI 114:12. (Cf. Ibid., p. 69-70) Ele também concorda com Kugel no que se refere a usar o paralelismo como um fator de identificação da PHB, visto que o fenômeno ocorre em textos de prosa. (Cf. Ibid., p. 77)

Sobre a definição de paralelismo, Gillingham afirma: "há uma necessidade de uma definição precisa (entretanto não rígida) de paralelismo, a qual vá além de Kugel, mas não tão longe quanto Lowth". ${ }^{200}$ A proposta dele é que o paralelismo seria de um tipo (na linha de Kugel) 'A, ainda mais B', mas esse 'mais' em termos de repetição ou contraste (na linha de Lowth) - sinônimo ou antitético. (Cf. Ibid., p. 78)

Essa mecânica acontece, segundo Gillingham, com certas variações. Por exemplo, a linha $A$ pode ser trocada com a linha $B(A=B)$, tanto em termos de eco, quanto de negação. (Cf. Ibid., p. 78-79) Ele exemplifica com SI 33:7 (cf. Ibid., p. 80):

Ele ajunta como em garrafa as águas do mar, ele põe em depósitos as profundezas. ${ }^{201}$

Outra variação é quando a linha $A$ é mais importante do que a linha $B$ e essa, por sua vez, apenas qualifica $A(A>B)$. Isso também pode ocorrer por repetição ou contraste. Ele menciona Pv 30:18 (cf. Ibid.):

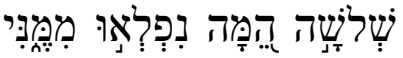

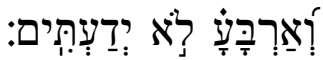

Três coisas são maravilhosas pra mim, e quatro eu não entendo. ${ }^{202}$

\footnotetext{
200 "[...] there is a need for a precise (although not rigid) definition of prallelism which goes beyond Kugel but not as far as Lowth."

${ }^{201}$ A divisão em versos segue a sugestão de Gillingham. (1994, p. 80) Sua tradução do hebraico foi: "He gathered the waters of the sea as in a bottle; / he puts the deeps in storehouses."
} 
A última variação do paralelismo segundo a ótica de Gillingham é quando a linha $A$ expressa uma ideia introdutória e a linha $B$ não somente complementa $A$, mas também a conclui $(A<B)$. Aqui ele cita Is $40: 3$ (cf. Ibid., p. 81):

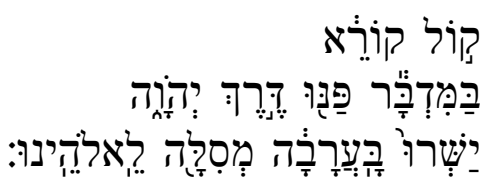

Uma voz clama

no deserto prepara o caminho de YHWH

endireita no ermo estrada para nosso Deus. ${ }^{203}$

Com fraseologia semelhante à de Clines, J. P. Fokkelman também entende que, quanto ao uso do paralelismo, "o todo é mais do que a soma das partes". ${ }^{204}$ (Fokkelman, 2001, p. 65) Para ele o paralelismo é uma parte do todo poético, mas não deve ser enxergado como algo restrito ao verso. Sua definição do poema hebraico é:

Um poema é o resultado de (por um lado) uma maneira artística de lidar com a linguagem, estilo e estrutura, e (por outro lado) aplicar proporções prescritas em todos os níveis do texto, para que uma combinação controlada de linguagem e número seja criada. ${ }^{205}$ (Ibid., p. 35)

Nessa definição do poema, o paralelismo seria um recurso que manteria o balanço e a equivalência entre a linguagem e o número não só no nível do verso, mas de toda a construção poética. (Cf. Ibid., p. 34) Como exemplo, ele cita um famoso trecho do SI 137 (cf. Ibid., p. 61):

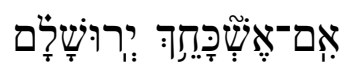

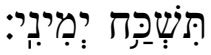

202 A divisão em versos segue a sugestão de Gillingham. (1994, p. 80) Sua tradução do hebraico foi: "Three things are too wonderful for me; / four I do not understand."

${ }^{203}$ A divisão em versos segue a sugestão de Gillingham. (1994, p. 81) Sua tradução do hebraico foi: "In the wilderness prepare the way of the Lord, / make straight in the desert a highway for our God."

204 "The whole is more than the sum of its parts [...]."

205 "A poem is the result of (on the one hand) an artistic handling of language, style and structure, and (on the other hand) applying prescribed proportions to all levels of the text, so that a controlled combination of language and number is created." 


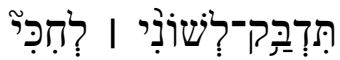

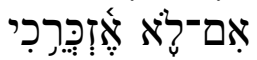

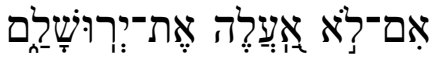

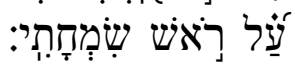

\begin{abstract}
Se eu te esquecer, Jerusalém, que esqueça minha mão direita;

que agarre-se minha língua ao meu palato

se eu não me lembrar de ti,

se eu não colocar Jerusalém

sobre a cabeça da minha alegria. ${ }^{206}$
\end{abstract}

Fokkelman acredita que SI 137:5-6 tenha sido organizado em um

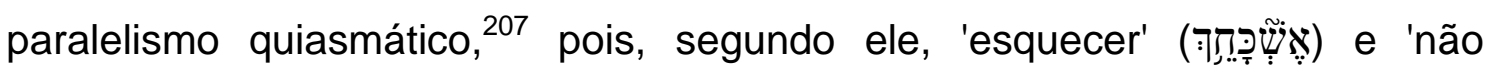

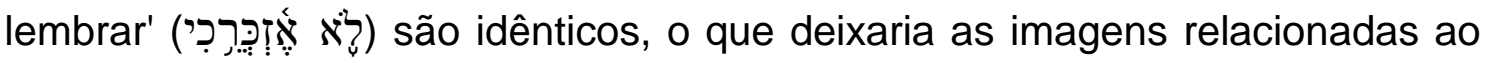
corpo no centro das primeiras quatro linhas. Ou seja, o poeta se sente fisicamente doente pelo simples fato de pensar em perder suas raízes. (Cf. Ibid., p. 61) A conclusão do pequeno trecho poético seria, segundo Fokkelman, as duas últimas linhas, quando novamente o poeta tenta "expressar a inexprimível" importância de Jerusalém para ele. (Cf. Ibid., p. 62)

Com este exemplo, Fokkelman tenta demonstrar o paralelismo como um recurso maior do que o verso, ou linha, e estabelecê-lo como o fator de unidade e alinhamento textual. (Cf. Ibid.)

A favor da ligação intrínseca entre paralelismo e linguagem, Nicholas Lunn ressalta a presença do paralelismo em diversas outras línguas. Assim, paralelismo seria uma característica que iria além do hebraico bíblico e mesmo de um ambiente semítico. O paralelismo teria sido identificado desde ugarítico até russo, turco e chinês, não apenas na poesia antiga, como na moderna também. (Cf. Lunn, 2006, p. 14)

Lunn também aponta a existência do paralelismo em nível semântico, sintático, morfológico, léxico e fonológico, mas ressalta que "paralelismo de significado é geralmente acompanhado de por um paralelismo de forma"208

\footnotetext{
${ }^{206}$ Fokkelman apresenta a tradução do texto de acordo com a RSV (Revised Standard Version): "If I forget you, O Jerusalem, / let my right hand whither; / let my tongue cleave to the roof of my mouth, / if I do not remember you, / if I do not set Jerusalem / above my highest joy." ${ }^{207}$ Quiasmo será definido e explicado na próxima parte desse capítulo.

208 "[...] parallelism of meaning is often accompanied by parallelism of form."
} 
(lbid., p. 15), ou seja, aonde há um relacionamento de significado, usualmente há algum tipo de relacionamento sintático, e como exemplo ele cita $2 \mathrm{Sm}$ 22:29 (cf. lbid.):

pois tu és minha lâmpada, YHWH;

e YHWH ilumina minha escuridão. ${ }^{209}$

As duas linhas se correspondem em significado (semanticamente equivalentes) e o relacionamento sintático também carrega paralelismo. A primeira linha é uma sentença nominal e a segunda verbal. ${ }^{210} \mathrm{Na}$ primeira sentença 0 autor se dirige a YHWH na segunda pessoa, enquanto na sentença seguinte, a referência é em terceira pessoa. Ainda que sejam, sintaticamente, diferentes, o paralelismo semântico é fortalecido pela seguinte nuance: o complemento da sentença nominal e o verbo da sentença verbal têm relação com 'luz' e, gramaticalmente, o tema dos dois é YHWH. (Cf. Ibid., p. 15-16)

Lunn também aventa a possibilidade de ocorrência de paralelismo para além do par de linhas, entre bicólons, e para aquém também, isto é, no próprio cólon/linha. (Cf. Ibid., p. 17-18)

Essa breve exposição cronológica sobre 0 desenvolvimento da discussão sobre o tema paralelismo revela que, embora o fenômeno tenha sido amplamente aceito (mesmo que com certas restrições) e estudado ao longo dos últimos séculos, ele se constitui em algo elaborado ao ponto de não ser esgotado. Como coloca Roman Jakobson:

Pode-se afirmar que na poesia a similaridade se superpõe à contigüidade (sic) e, assim, 'a equivalência é promovida a princípio constitutivo da seqüência' (sic). Nela toda reiteração perceptível do mesmo conceito gramatical torna-se um procedimento poético efetivo. Uma descrição não-apriorística, atenta, exaustiva, completa, dos processos de seleção, distribuição e inter-relacionamento das diferentes classes morfológicas e das diferentes construções sintáticas presentes em um dado poema surpreende até mesmo o investigador que

\footnotetext{
${ }^{209}$ A divisão em versos segue a sugestão de Lunn. (2006, p. 15) Sua tradução do hebraico foi: "For you are my light, O YHWH; / and YHWH lightens up my darkness."

${ }^{210}$ Seguindo a descrição de Adele Berlin, esse seria um paralelismo gramatical sintático. (Cf. Berlin, 1985, p. 54-56)
} 
a realiza. Surpreendem-no simetrias e anti-simetrias (sic) inesperadas, notáveis, as estruturas balanceadas, a acumulação eficiente de formas que se equivalem e contrastes que sobressaem e, finalmente, as eliminações, consequentes (sic) e severas restrições no repertório dos constituintes morfológicos e sintáticos usados no poema, as quais permitem, por outro lado, acompanhar a hábil integração dos constituintes nele realizados. (Jakobson, 1970, p. 72-73)

\section{Capítulo 3}

PRODUTOS DO PARALELISMO E UM PRINCíPIO GERAL 
Por seu papel central na PHB, o paralelismo acaba por gerar uma série de produtos que, embora possam ser analisados separadamente, estão conectados em diversos níveis ao seu conceito geral.

A seguir apresentamos esses produtos e um princípio geral para análise da PHB.

\subsection{QUIASMO}

O quiasmo é um tipo específico de paralelismo. Consiste de uma sequência de componentes repetidos e em ordem invertida é conhecida como quiasmo. O nome é derivado da letra grega chi, cuja escrita é ' $X$ ' (como um xis). A repetição pode ocorrer em nível fonético, léxico, gramatical e semântico. (Cf. Overland, 2008, p. 54)

Já na época de Gray esse padrão de repetição, ou paralelismo, era reconhecido, mas não com o termo técnico 'quiasmo'. Gray empregava letras minúsculas do alfabeto para designar cada termo na linha - sistema que se tornou "universalmente" empregado por estudiosos da $\mathrm{BH}$ - e, ao apontar as diversas variações do paralelismo, verificou o padrão abc//c'b'a' (Cf. Freedman, 1980, p. 25)

Mas as possibilidades de um arranjo quiasmático não se resumem à repetição como em um espelho, como visto por Gray. Na verdade, segundo O'Connor, existem seis possibilidades: 1) ordem quiasmática simples com

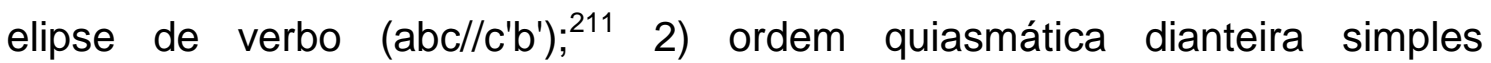
$\left(a b c / / b^{\prime} a^{\prime} c^{\prime}\right)$; 3) ordem quiasmática traseira simples (abc//a'c'b'); 4) ordem quiasmática dianteira invertida (abc//c'a'b'); 5) ordem quiasmática traseira invertida (abc//b'c'a'); e, como já citado, 6) ordem quiasmática de espelho (abc//c'b'a'). Essas possibilidades não se resumiriam apenas ao par de linhas (ou bicólon), mas teriam aplicabilidade em larga escala, ou seja a todo o

${ }^{211}$ O'Connor, como em outros momentos já expostos nesse trabalho, usa uma terminologia própria e, nesse caso, em vez do usual padrão de letras (abc), se utiliza de números. (1980, p. 393) 
poema. (Cf. O'Connor, 1980, p. 393-394) As possibilidades apontadas por O'Connor estão focadas na ordem dos elementos da linha.

Na mesma orientação de O'Connor, Lunn define o quiasmo como a reordenação dos componentes da segunda linha em relação à primeira, mantendo aspectos em comum. Entretanto, Lunn emprega a terminologia de quiasmo preciso ou parcial: ${ }^{212} \mathrm{o}$ primeiro se referindo à ordem quiasmática de espelho e o segundo a todas as outras cinco possibilidades apontadas por O'Connor. Lunn analisa que quando houver três partes constituintes de uma linha (ou cólon), a chance de um paralelismo quiasmático preciso ocorrer é muito pequena (cf. Lunn, 2006, p. 107-108) e também O'Connor fala sobre a raridade do quiasmo de espelho. (Cf. O'Connor, 1980, p. 394)

Em SI 7:17, ${ }^{213}$ Lunn exemplifica o que seria esse quiasmo preciso com linhas de três componentes (cf. Lunn, 2006, p. 108):

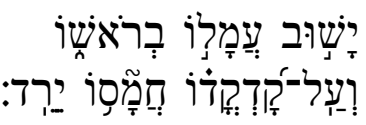

Retornará sua maldade em sua própria cabeça;

e sobre seu próprio crânio sua violência descerá. ${ }^{214}$

Na primeira linha o verbo שiּ inicia a sentença e está no Qal imperfeito, na terceira pessoa masculino singular, paralelo ao verbo ירד que termina a sentença da segunda linha e também está no Qal imperfeito, na terceira pessoa masculino do singular. O mesmo ocorre com os dois componentes da primeira linha - um substantivo e um modificar - que estão invertidos na segunda linha. (Cf. Lunn, p. 108)

Berlin, por sua vez, trabalha o padrão do quiasmo (ab//b'a') sob 0 desenho léxico, gramatical e semântico. No primeiro ela cita Jr 17:7 (cf. Berlin, 1985, p. 85):

\footnotetext{
${ }^{212}$ Aqui Lunn segue a terminologia de Watson. (1984, p. 203)

${ }^{213}$ Na ARA, SI 7:16.

${ }^{214}$ A divisão em versos segue a sugestão de Lunn. (2006, p. 108) Sua tradução do hebraico foi: "His mischief will return upon his own head, / and his violence will descend upon his own crown."
} 
Bendito é o homem que confia em YHWH; e é YHWH sua confiança. ${ }^{215}$

Para ilustrar o quiasmo gramatical ela refere-se ao SI 137:5-6a (cf. Ibid., p. 86):

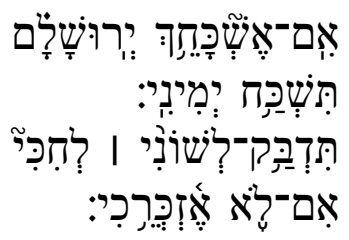

Se eu te esquecer, Jerusalém, que esqueça minha mão direita; que agarre-se minha língua ao meu palato, se eu não me lembrar de ti. ${ }^{216}$

O paralelismo quiasmático nesse caso está além do par de linhas e se mostra como um recurso estrutural importante na construção do poema. $\mathrm{Na}$ primeira linha, além da partícula de hipótese אם, há o verbo no Qal imperfeito na primeira pessoa comum do singular com sufixo de segunda pessoa feminino do singular. Na última linha também temos a composição partícula de hipótese mais verbo no Qal imperfeito na primeira pessoa comum do singular com sufixo de segunda pessoa feminino do singular. Nas duas linhas centrais a estrutura é similar, com verbo no Qal imperfeito na terceira pessoa feminino do singular iniciando a ideia, seguido de substantivo com sufixo de primeira pessoa do singular. Assim, há um quiasmo gramatical de espelho. ${ }^{217}$

No desenho semântico, o quiasmo funcionaria como elucidado em Pv 23:15-16 (cf. lbid., p. 87):

\footnotetext{
${ }^{215}$ A divisão em versos segue a sugestão de Berlin. (1985, p. 85) Sua tradução do hebraico foi: "Blessed is the man who is secure in YHWH; / and YHWH will be his security."

${ }^{216}$ A divisão em versos segue a sugestão de Berlin. (1985, p. 86) Sua tradução do hebraico foi: "If I forget you, Jerusalem, / Let my right hand wither; / let my tongue stick to my palate, / If I do not remember you."

${ }^{217}$ Nesse caso, entretanto, há de se levar em conta que o quiasmo sugerido por Berlin não é tão 'preciso' assim, visto que o verbo da última linha contém uma negação ausente na construção da primeira linha e que a terceira linha, em paralelo com a segunda, apresenta dois substantivos ao invés de um.
} 
Filho meu, se é sábio teu coração, regozijará meu coração comigo;

e exultarão meus rins,

em falar teus lábios o que é reto. ${ }^{218}$

Segundo Berlin, seus exemplos são os mais simples e óbvios, pois o que ela procura é demonstrar que embora os diferentes quiasmos apenas acrescentem efeito ao paralelismo, esse, por sua vez, é o resultado de diversos efeitos criados pelos muitos aspectos da linguagem. (Cf. Ibid., p. 87-88)

Kugel reconhece o quiasmo como um recurso inegável do hebraico bíblico e coloca que o mesmo não deve ser separado do contexto paralelístico, muito embora o quiasmo seja exatamente a decisão de não colocar em paralelo a ordem das palavras de A em B. (Cf. Kugel, 1981, p. 19) Ele faz referência a Ez 36:26 como modelo (cf. Ibid., p. 20):

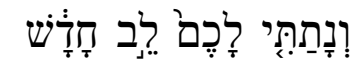

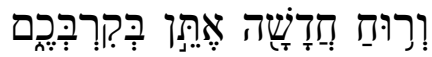

e dar-vos-ei coração novo

e espírito novo colocarei no vosso interior. ${ }^{219}$

No modelo acima, Kugel ainda revela a similaridade entre a questão da alternância verbal "Qatal-Yiqtol"220 e o quiasmo, enfatizando que ambos são parte do efeito da variação da ordem das palavras no paralelismo e que causam a mesma sensação estética. (Cf. Ibid.)

\footnotetext{
${ }^{218}$ A divisão em versos segue a sugestão de Berlin. (1985, p. 87) Sua tradução do hebraico foi: "My son, if our heart is wise, / my own heart will rejoice; / my kidneys will be glad, / when your lips speak rightly."

${ }^{219}$ A divisão em versos segue a sugestão de Kugel. (1981, p. 20) Sua tradução do hebraico foi: "I will give you a new heart / and a new spirit will I put in your midst."

220 Kugel a indica como "qtl-yqtl". (Cf. Kugel, 1981, p. 20) Jüon e Muraoka usam a nomenclatura Qatal/perfeito e Yiqtol/futuro. (Cf. Jüon e Muraoka, 2009, p. 330 e 337) Já Greenberg prefere perfeito e imperfeito. (Cf. Greenberg, 1965, p. 45 e 49) Halabé escolhe denominar Qatal de 'forma sufixa' e Yiqtol de 'forma prefixa'. (Cf. Halabé, 2011, p. 230) Para uma breve discussão sobre a terminologia, ver Merwe, Naudé e Kroeze. (1999, p. 141-144)
} 
Wilfred Watson define quiasmo como uma série ( $a, b, c)$ e seu inverso (c, b, a) em uma unidade combinada, geralmente em um par de linhas, como em Jr 4:5a (cf. Watson, 1984, p. 201-202):

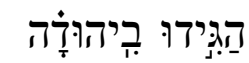

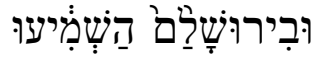

Anuncia em Judá

e em Jerusalém faze ouvir ${ }^{221}$

Nesse caso o substantivo precedido de preposição encerra a primeira linha e abre a segunda, ao passo que o verbo no Hifil imperativo começa a primeira linha e termina a segunda. No caso, como apontado por Watson, o paralelismo quiasmático é gramático, mas também semântico. (Cf. Ibid., p. 202)

Mas Watson, como Berlin e O'Connor, também prevê que o padrão quiasmático pode emergir além do par de linhas. Sobre o uso do quiasmo, inclusive, ele menciona que o mesmo aparece na poesia acadiana e ugarítica, mas não tão desenvolto como em hebraico. (Cf. Ibid.)

A tipologia desenvolvida por Watson, primariamente, prevê quatro espécies de quiasmos semânticos no par de linhas. O primeiro tipo seria o já visto quiasmo de 'espelho'. Watson ilustra com Is 22:22 (cf. lbid., p. 203):

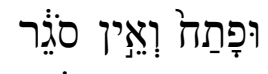

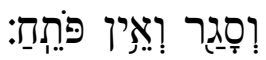

Ele abrirá e ninguém fechará, e ele fechará e ninguém abrirá. ${ }^{222}$

No trecho acima há uma situação especial. O verbo que abre a primeira linha é o mesmo que fecha a segunda linha e o que fecha a primeira linha é o que abre a segunda, tudo com a manutenção do mesmo substantivo no meio dos dois verbos. Entretanto, se olharmos unicamente para o verbo, veremos que, gramaticalmente o par de linhas oferece uma outra leitura: as duas linhas são abertas por verbos no $Q a l$ perfeito na terceira pessoa masculino do

\footnotetext{
${ }^{221}$ A divisão em versos segue a sugestão de Watson. (1984, p. 202) Sua tradução do hebraico foi: "Broadcast in Judah / and in Jerusalem proclaim!"

${ }^{222}$ A divisão em versos segue a sugestão de Watson. (1984, p. 203) Sua tradução do hebraico foi: "He shall open and no one will shut, / he shall shut and no one will open."
} 
singular, enquanto o segundo verbo de ambas está no Qal particípio ativo, ou seja, temos abc//abc, sendo 'b' o substantivo nos dois casos.

O segundo tipo de quiasmo seria o 'completo'. Aqui Watson parece criar uma pequena distinção entre a espécie 'espelho' e a 'completo', já que sua definição é muito próxima. Quanto ao quiasmo 'espelho', ele diz: "a segunda linha repete os componente da primeira em sequência reversa"; 233 e no quiasmo 'completo' define: "todos os elementos compreendidos no segundo cólon estão dispostos na ordem reversa do primeiro". ${ }^{224}$ (Cf. Ibid., p. 203)

O exemplo relacionado por Watson para o quiasmo 'completo', Jr 2:19, se avizinha do anterior (cf. Ibid.):

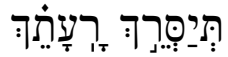

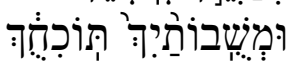

castigar-te-á tua maldade,

e tua apostasia e reprovará; ${ }^{225}$

Quiasmo de 'membros divididos' é outro tipo relacionado por Watson. Nesse caso ocorre uma variação do quiasmo 'completo', ou seja, em vez de abc//c'b'a', temos abc//b'c'a' e similares, com a alteração de posição de um dos elementos. Isso ocorre em Pv 7:21 (cf. Ibid.):

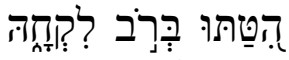

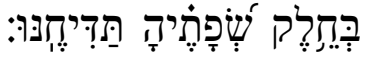

Ela o persuade com seu discurso sedutor com a sedução dos seus lábios ela o obriga. ${ }^{226}$

Por fim, Watson oferece o último tipo, o quiasmo 'parcial', que, resumidamente, é quando um dos elementos aparenta estar em elipse em uma das linhas, como em SI 143:1 (cf. Ibid., p. 203-204):

\footnotetext{
${ }^{223}$ "[...] the second line repeats the components of the first in reverse sequence [...]."

224 "[...] all the elements comprising the second colon are set out in reverse order of the first."

${ }^{225}$ A divisão em versos segue a sugestão de Watson. (1984, p. 203) Sua tradução do hebraico foi: "You will be punished by your wickdness, / your defections will convict you;"

${ }^{226}$ A divisão em versos segue a sugestão de Watson. (1984, p. 203) Sua tradução do hebraico foi: "She led him on with her many persuasions, / by her smooth talk she pressed him."
} 
YHWH ouve minha oração,

inclina teus ouvidos para minhas súplicas

Sobre quiasmo, Schökel atesta: "são normalmente achados em um espaço restrito; os elementos repetidos são achados próximos uns dos outros". ${ }^{227}$ Ele ilustra o conceito com Ct 6:3 (cf. Schökel, 2000, p. 79):

Eu sou do meu amado

e meu amado é meu ${ }^{228}$

Outro exemplo dado por Schökel e que abrange um espaço maior, quatro linhas, é SI 113:2-3 (cf. Ibid., p. 59):

Seja o nome de YHWH abençoado

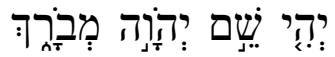

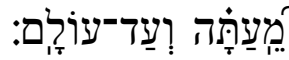

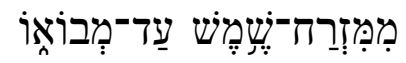

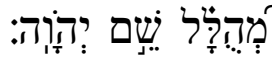
de agora e até a eternidade.

Do nascer do sol até seu ocaso é louvado o nome de YHWH. ${ }^{229}$

Nota-se um quiasmo gramatical: os dois verbos, הלל e estão no particípio Pual, o primeiro fechando a primeira linha e o segundo abrindo a última linha. Ademais, a expressão construta שֶׁם יהוה antecede o primeiro verbo na primeira linha e o sucede na última linha. Já as linhas centrais guardam pouca semelhança gramatical, a não ser pelo uso da expressão

\footnotetext{
227 "[...] are normally found in a restricted space; the repeated elements are found near each other."

${ }^{228}$ A tradução de Schökel do hebraico foi: "I am my beloved's, and my beloved is mine."

${ }^{229}$ A divisão em versos segue a sugestão de Schökel. (2000, p. 59) Sua tradução do hebraico foi: "Blessed be the name of the Lord / from this time forth and for evermore! / From the rising of the sun to its setting / the name of the Lord is to be praised."
} 
conjuntiva עד. Entretanto, possuem um paralelismo semântico em virtude do merisma ${ }^{230}$ de ambas.

Schökel admite que possa haver um posicionamento quiasmático de elementos a uma certa distância e que, tanto o quiasmo de elementos próximos, quanto o de termos distantes é um fenômeno frequente na PHB. (Cf. Ibid., p. 79)

Wendland e Zogbo também introduzem o quiasmo como uma variação do paralelismo e também consideram que pode acontecer tanto em um par de linhas, quanto em um poema inteiro. Um exemplo citado de um quiasmo que abrange todo um poema é Ec 3:1-8, com uma série de paralelismos quiasmáticos diferentes (cf. Wendland e Zogbo, 2000, p. 31-32):

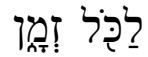

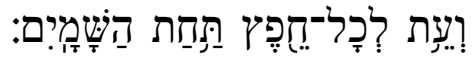

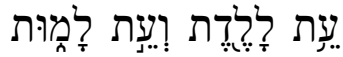

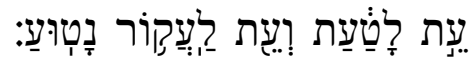

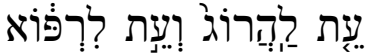

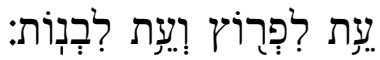

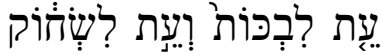

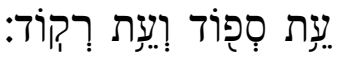

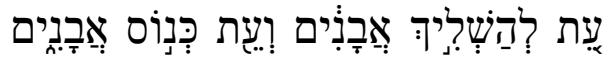

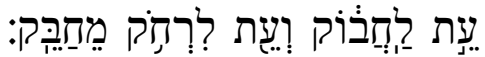

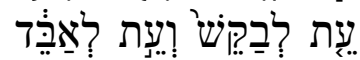

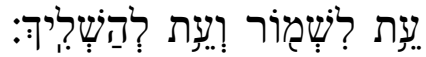

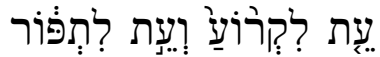

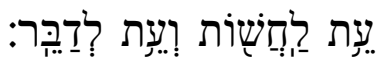

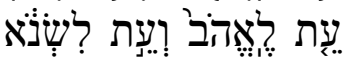

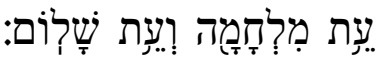

v.1 Para tudo existe uma hora

e um tempo para todo deleite debaixo do sol.

v.2 Um tempo para nascer e um tempo para morrer.

Um tempo para plantar e um tempo para arrancar o que foi plantado.

v.3 Um tempo para matar e um tempo para curar.

Um tempo para quebrar e um tempo para construir.

v.4 Um tempo para chorar e um tempo para rir.

Um tempo para lamentar e um tempo para dançar.

${ }^{230}$ Merisma é um tipo de sinédoque, quando os limites de alguma coisa da mesma categoria são colocados lado a lado para expressar totalidade. (Cf. Salisbury, 2004, p. 17) Será explicada e exemplificada mais à frente. 
v.5 Um tempo para jogar fora pedras e um tempo para apanhar pedras.

Um tempo para abraçar e um tempo para evitar abraçar.

v.6 Um tempo para procurar e um tempo para perder.

Um tempo para manter e um tempo para jogar fora.

v.7 Um tempo para rasgar e um tempo para costurar.

Um tempo para silenciar e um tempo para falar.

v.8 Um tempo para amar e um tempo para odiar.

Um tempo para guerra e um tempo para paz. ${ }^{231}$

Nas duas primeiras linhas, Wendland e Zogbo assinalam um padrão paralelístico quiasmático já que a primeira linha contém o substantivo זמן, relativo a tempo, enquanto a segunda linha se inicia com outro substantivo relativo a tempo, עת ${ }^{232}$ Ainda apontam quiasmo no fechamento do poema (Ec 3:8), nas duas últimas linhas, já que "tempo de amar", que abre a 15a linha, é positivo e "tempo para paz", que fecha a 16믈 também, ao passo que "tempo para odiar", que fecha a 15a , é negativo e "tempo para guerra", no início da 16 ${ }^{\underline{a}}$ linha, idem. (Cf. Ibid., p. 31)

Aliás, justamente baseados nessa alternância de ideias positivas e negativas, Wendland e Zogbo estruturam os quiasmos em todo o texto: $3^{\underline{a}}$ e $4^{\underline{a}}$ linha se iniciam com ideias positivas ("tempo de nascer" e "tempo de plantar") e fecham com ideias negativas ("tempo para morrer" e "tempo para arrancar o que foi plantado"), ao mesmo tempo em que da $5^{\underline{a}}-8^{\underline{a}}$ linha a primeira ideia é negativa ("tempo de matar", "tempo de quebrar", "tempo de chorar", "tempo de lamentar") e a segunda positiva ("tempo de curar", "tempo para construir", "tempo para rir" e "tempo para dançar"). Ter-se-ia o quiasmo 'positivo-negativo $x$ negativo-positivo'. (Cf. Ibid.)

Continuando, da $9^{a}$ à $12^{a}$ linha o primeiro aspecto de cada uma é positivo ("tempo para jogar fora pedras", "tempo para abraçar", "tempo para procurar", "tempo para manter") e o segundo negativo ("um tempo para apanhar pedras", "um tempo para evitar abraçar", "um tempo para perder", "um tempo para jogar fora"), enquanto que na $13^{\text {a }}$ e $14^{\text {a }}$ há a inversão, primeiro o negativo ("tempo para rasgar", "tempo para silenciar") e depois o positivo

\footnotetext{
${ }^{231}$ A divisão em versos segue a sugestão de Wendland e Zogbo. (2000, p. 31-32) Em virtude da análise deles seguir de acordo com os versos, apresentamos os mesmos na tradução.

232 Nesse caso, o primeiro substantivo, זמן, é masculino e o segundo, עת, feminino, o que envolveria um quiasmo de gênero, mas todos outros substantivos (שמים , חפץ , כל ) são masculinos também.
} 
("tempo para costurar", "tempo para falar"). Assim, o mesmo quiasmo anterior, 'positivo-negativo x negativo-positivo', é repetido. (Cf. Ibid., p. 32)

Conclusão, o padrão quiasmático cria um quiasmo estrutural em todo o poema de Ec 3:2-8, a saber, 'positivo-negativo x negativo-positivo': são duas linhas com 'positivo-negativo' seguidas de quatro linhas 'negativo-positivo', com um inverso na sequência, já que são quatro linhas 'positivo-negativo' e depois duas 'negativo-positivo'. O último verso (as duas últimas linhas) traz esse quiasmo estrutural em sua composição interna. Eles colocam de maneira visual (cf. Ibid.):

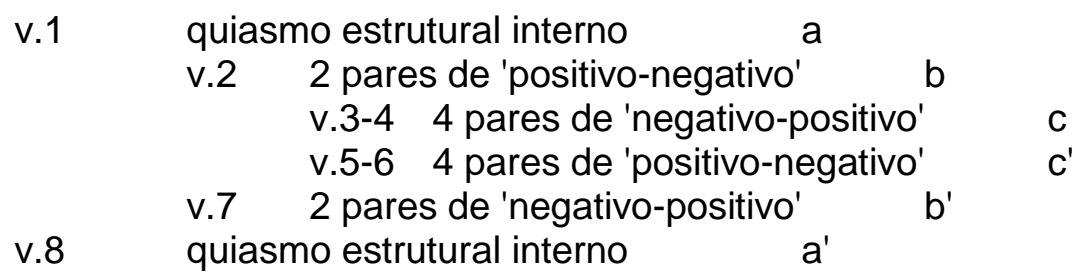

O quiasmo acima apresentado por Wendland e Zogbo realça uma de suas convicções: "estruturas quiasmáticas não contêm sempre paralelos perfeitos em forma e significado". (Cf. Ibid., p. 30)

Quanto a essa ideia, Watson parece ser contrário. Ao tratar de paralelismo quiasmático em seções grandes, como o do poema analisado por Wendland e Zogbo, ele estabelece uma série de quatro controles para que o verdadeiro quiasmo seja percebido: ele precisa ser estrito, abranger todo o texto, repetir palavras e estruturas, ter uma base clara. (Cf. Watson, 1994, p. 355-356)

Isso porque o quiasmo, segundo ele, pode ser confundido com outros elementos poéticos, como o refrão ou a repetição de palavras-chave. Ao mesmo tempo, o quiasmo pode se aproveitar desses mesmos elementos para se estabelecer. (Cf. Ibid., p. 383-385) 
Ilustrando seu ponto com o mesmo texto empregado por Wendland e Zogbo, Watson esboça uma outra estrutura alinhada com seus controles (cf. Ibid., p. 366-367): $:^{233}$

$$
\begin{aligned}
& \text { v.1 } \\
& \text { v.2 'positivo-negativo' A } \\
& \text { 'positivo-negativo' } \\
& \text { v.3 'negativo-positivo' B } \\
& \text { v.4 'negativo-positivo' } \\
& \text { v.5 } \\
& \text { 'negativo-positivo' } \\
& \text { v.5 'positivo-negativo' B' } \\
& \text { v.7 'negativo-positivo' } \quad A^{\prime} \\
& \text { 'positivo-negativo' } \\
& \text { 'positivo-negativo' } \\
& \text { 'negativo-positivo' } \\
& \begin{array}{ll}
\text { v.8 'positivo-negativo' } \\
\text { 'negativo-positivo' }
\end{array}
\end{aligned}
$$

Watson ainda estabelece as funções principais do uso do quiasmo. (Cf. Ibid., p. 368-373) Dentre essas funções, ele destaca que o paralelismo quiasmático indica o ponto central do poema. Esse ponto central pode representar duas coisas: ou o clímax do poema, ou seu ponto de mudança. (Cf. Ibid., p. 370)

David Dorsey relaciona 'padrão simétrico' a quiasmo e sustenta que é um componente comum na BH. Segundo ele, versos, seções e mesmo livros são organizados nesse padrão de simetria. Dorsey relaciona dois tipos de quiasmo: o simétrico ${ }^{234}$, com centro duplo, representado pela estrutura abc//c'b'a'; e o quiasmo assimétrico, com centro único, representado pela estrutura a-b-c-b'-a'. (Cf. Dorsey, 1999, p. 30-31)

Um exemplo dado por Dorsey do quiasmo simétrico é o já citado texto de Is $22: 22$ (cf. Ibid., p. 31):

\footnotetext{
${ }^{233}$ Mesmo aplicando seus controles, Watson exclui o primeiro verso e ignora a primeira parte do quinto verso.

${ }^{234}$ Como já visto, chamado por O'Connor e Watson, por exemplo, de quiasmo de espelho.
} 
a. Ele abrirá

b. e ninguém fechará,

b'. e ele fechará

a'.e ninguém abrirá. ${ }^{235}$

Como exemplo de um quiasmo assimétrico, Dorsey relaciona a seção de Juízes 3:7 até 16:31236 (cf. Ibid., p. 31):

a. Otniel e sua boa esposa (3:7-11)

b. Eúde e a vitória nos vaus do Jordão (3:12-31)

c. Débora: o crânio inimigo esmagado pela mulher (4:1-5:31)

d. Gideão: ponto de mudança (6:1-8:32)

c'. Abimeleque: crânio de juiz esmagado pela mulher (8:33-10:5)

b'. Jefté e a guerra civil nos vaus do Jordão (10:6-12:15)

a'. Sansão e suas más esposas (13:1-16:31)

Dentre as funções do quiasmo destacadas por Dorsey, está também o conceito de que ele aponta para o clímax ou ponto de mudança do poema (ou da seção, ou do livro). O adendo feito por Dorsey é que em um quiasmo simétrico ou assimétrico o centro dele é o centro do poema, visto que todas as suas partes simétricas apontariam para a única não simétrica. (Cf. Ibid.) 0 centro ou clímax, é o ponto alto do poema e foi arranjado quiasmaticamente pelo autor para que assim fosse. (Cf. Ibid., p. 40-41)

De maneira distinta de Watson, Dorsey parece buscar o quiasmo e em vez de controles, apresenta categorias que ligariam as partes do texto em um quiasmo (em poemas maiores ou mesmo livros inteiros), com um total de quinze: repetição verbatim, repetição quase verbatim, repetição de lugares, repetição de participantes, repetição de tempo, repetição de gênero, repetição de velocidade da ação, repetição de forma literária, repetição de atmosfera, repetição de tópico ou tema, repetição de cláusulas de início, repetição de palavras-chave ou frases, recorrência de sinônimos, repetição de motivochave, similaridade estrutural. (Cf. Ibid., p. 32-33)

\footnotetext{
${ }^{235}$ A divisão em versos segue a sugestão de Dorsey. (1999, p. 31) Sua tradução do hebraico foi: "he shall open / and no one will shut / he shall shut / and no one will open." A representação visual da estrutura foi mantida.

${ }^{236}$ Dorsey não transcreve todo o texto em hebraico e nem registra palavras ou expressões do hebraico. Nós também não o faremos. Os nomes seguem a tradução da ARA.
} 
Com todas essas categorias, a posição de Dorsey quanto ao quiasmo fica explícita na declaração:

Quanta repetição entre unidade é suficiente para criar um paralelo? Uma única palavra, por exemplo, é suficiente para conectar duas unidades não-adjacentes? Possivelmente - se a palavra é um termo chamativo que carrega algum peso temático em ambas as passagens e ocorre em nenhum outro lugar do contexto. ${ }^{237}$ (Ibid., p. 33)

A questão levantada por Dorsey sobre a quantidade de repetição necessária para gerar quiasmo é repetida por Roberts, mas com resposta oposta. Para ele os exemplos mais claros de quiasmo ocorrem com a repetição léxica completa e em textos relativamente curtos, como em Is 6:10 (cf. Roberts, 2001, p. 85):

faz insensível o coração desse povo,

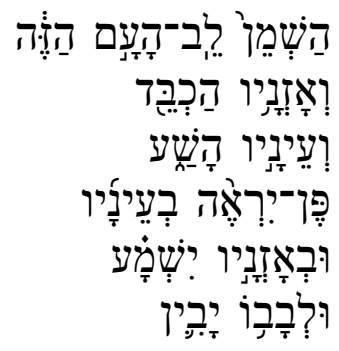

e seus ouvidos faz pesados,

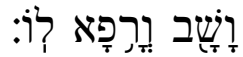
e seus olhos faz selados, para que eles vejam com seus olhos e com seus ouvidos escutem e com o coração entendam

e voltem e sejam curados.

Ainda que a última linha não seja paralela e sim complementar, toda a construção inicial é revertida. O que Roberts procura alertar é que a "tentação de identificar estruturas quiasmáticas em largas porções poéticas somente em termos de correspondência temática tem se provado grande". ${ }^{238}$ (Ibid., p. 85)

\footnotetext{
237 "How much repetition between units is enough to create a match? Is a single word, for example, enough to connect two nonadjacent units? Possibly - if the word is a striking term that carries some thematic weight in both passages and occurs nowhere else in the context."

${ }^{238}$ "[...] the temptation to identify chiastic structures in large poetic texts solely on the basis of thematic correspondence has proven to be very great."
} 
Suas considerações ainda levam em conta que a repetição, especialmente em PHB, é altamente recorrente e facilita o talho de estruturas quiasmáticas destacando alguns termos e ignorando outros. Ele ainda aponta que a presença de um incluso ${ }^{239}$ acaba sendo um convite ao preenchimento de um completo quiasmo que não está presente. (Cf. Ibid.)

A conclusão de Roberts sobre quiasmo, que também representa a conclusão do autor desse trabalho, é que

quanto menor a unidade textual sob consideração, e quanto maior a intensidade léxica da repetição, maior a probabilidade que um quiasmo esteja realmente presente como um elemento estrutural. De maneira inversa, quanto mais larga a unidade e quanto mais dependente a análise é do resumo temático, maior o perigo de que o quiasmo tenha sido criado pelo intérprete. ${ }^{240}$ (Ibid., p. 85-86)

\subsection{MÉTRICA}

A discussão sobre a métrica na PHB é antiga e abrange séculos (cf. Vance, 1997, p. 48; Kugel, p. 1981, p.71), desde a época de Filo, Josefus e Jerônimo (cf. Leatherman, 1998, p. 2), grandemente influenciada pela métrica grega e latina. Mas é a partir de Lowth e de seu conceito de parallelismus membrorum que a questão passa a ser sistematicamente discutida. (Cf. Vance, 1997, p. 2)

Lowth, em sua terceira leitura chega a afirmar categoricamente que a poesia hebraica é métrica. (Cf. Lowth, s/d, 32) O título dessa leitura é, inclusive, The Hebrew Poetry is Metrical. (Ibid., p. xv) Lowth diferencia a métrica hebraica da métrica da poesia grega e latina (cf. Ibid., p. 32-36), expondo que ela seria marcada pelo paralelismo dos membros da linha (cf. Vance, 1997, p. 3) mas,

\footnotetext{
${ }^{239}$ Conhecido como inclusio ou paralelismo envelope é quando uma palavra, frase ou conceito é repetido no início e no final da unidade de discurso, ou estrofe. Geralmente se dá pela repetição exata de uma linha ou par de linhas nas extremidades da unidade, como em Ct 2:1013. (Cf. Salisbury, 2004, p. 11)

240 "[...] the smaller the textual unit under consideration, and the greater the intensity of lexical repetition, the greater the likelihood that chiasmus is actually present as a structuring device. Conversely, the larger the unit and the more dependent the analysis is on the thematic summary, the greater the danger the chiasmus has been created by the interpreter."
} 
embora assumisse a existência da métrica, ele evitou estabelecer um sistema métrico, insistindo que o mesmo havia se perdido. (Cf. Leatherman, 1998, 26)

Gray parece resumir o debate da seguinte forma: "métrica na literatura Hebraica é obscura: as leis da métrica hebraica têm sido e são motivo de disputa e em alguns momentos, a própria existência da métrica no Antigo Testamento tem sido questionada". ${ }^{241}$ (Gray, 1915, p. 47) A questão real, então, segundo Roberts, é se realmente existiria algum sistema definido de métrica na PHB. (Cf. Roberts, 2001, p. 60)

Mesmo assim, alguns sistemas métricos foram sugeridos ao longo do tempo, como o acentual, o silábico, etc. Apresentamos a seguir as principais teorias.

\subsubsection{QUANTITATIVO}

Este sistema se baseia no cumprimento da sílaba (longa ou curta), que é determinado pelo tempo que se demora para pronunciar cada uma. A sílaba longa, teoricamente, demoraria o dobro de tempo para ser pronunciada em relação à sílaba curta. Esse sistema é análogo ao usado na poesia grega e latina e, ao utilizá-lo, se assume que a PHB é similar a ambas. (Cf. Vance, 1997, p. 49)

Uma série de intelectuais antigos seguiu esse sistema, dentre eles, Filo de Alexandria, Josefo e Orígenes. (Cf. Ibid., p. 49-56) Kosmala expressa sua preocupação e desagravo por essa similaridade dizendo:

Olhamos para a poesia hebraica da mesma maneira com que nos aproximamos da poesia grega ou latina: escaneamos os versos, contamos as sílabas julgando-as pelo cumprimento de suas vogais ou pelos acentos na suposição a antiga poesia hebraica estava seguindo as mesmas regras da poesia grega

241 "[...] metre in Hebrew literature is obscure: the laws of Hebrew metre have been and are matters of dispute, and at times the very existence of metre in th Old Testament has been questioned." 
ou latina, ou de qualquer arte poética moderna. Bem - ela não está! ${ }^{242}$ (Kosmala, 1964, p. 424)

\subsubsection{ACENTUAL}

O sistema métrico acentual conta o número de sílabas acentuadas em uma linha. O número de sílabas não acentuadas é irrelevante e muito variável, mas o número de sílabas acentuadas deve ser fixo. (Cf. Vance, 1997, p. 101) É o sistema mais comumente usado na PHB. (Cf. Roberts, p. 60)

Foi a partir do século XVIII que esse sistema se desenvolveu, principalmente graças aos trabalhos de Julius Ley, Karl Budde e Eduard Sievers (cf. Ibid.), sendo que Ley foi considerado, já em sua época, como o "fundador ciência métrica". (Cf. Vance, 1997, p. 109)

Ley, inclusive, faz uma distinção entre paralelismo e métrica, dizendo que o paralelismo é um guia da métrica, mas não é sua lei, pois mesmo quando não há paralelismo, a métrica permanece mantendo o balanço, a simetria e a proporção entre as linhas. (Cf. Ibid., p. 120) Pode-se notar que, a partir desse tipo de conclusão, parece haver um distanciamento entre métrica e paralelismo.

De maneira semelhante, Gray diz:

[...] paralelismo é mais geralmente incompleto; e, ademais, junto com linhas completamente paralelas e linhas incompletamente paralelas vão ocorrer, frequentemente linhas não conectadas pela presença de algum termo paralelo. $\mathrm{E}$ ainda assim, do mesmo modo em que paralelos incompletos, e em pares não paralelos, vai geralmente ser encontrado, consistentemente mantido, o mesmo tipo de ritmo como naquelas que são completamente paralelas. ${ }^{243}$ (Gray, 1915, p. 123)

\footnotetext{
242 "We looked upon Hebrew poetry in the same way as we approached Greek and Latin poetry: we scanned the verses, we counted the syllables judging them by the length of their vowels or their stresses on the assumption that ancient Hebrew poetry was following the same rules as Greek or Latin poetry or any modern poetic art. Well-it does not!"

243 "[...] the parallelism is more often incomplete; and, moreover, along with lines completely parallel and lines incompletely parallel there frequently occur also lines unconnected by the presence in them of any parallel terms. And yet, alike in the incompletely parallel, and in the
} 
A afirmação de Gray é relevante não apenas por manter a tendência de distanciamento entre os conceitos de paralelismo e métrica, mas também por se referir a ritmo em detrimento de métrica. (Cf. Vance, 1997, p. 164)

Schökel também evita o uso do termo 'métrica' e serve-se do conceito de ritmo, até fazendo relação com a música. (Cf. Schökel, 2000, p. 34-35) Quanto ao sistema acentual, Schökel é enfático ao pontuar que "é o mais convincente para explicar e ouvir o ritmo poético hebraico". ${ }^{244}$ (Ibid., p. 45)

Uma constante nesse tipo de sistema é a crítica à vocalização Massorética (cf. Vance, 1997, p. 172), a qual não impede que se estabeleça um padrão de acentuação para o par de linhas. Esse padrão acentual é, na verdade, uma relação de possibilidades e que, conforme o pesquisador, muda de ênfase, por exemplo: Mowinckel relaciona o paralelo 4:4 (quatro acentos em cada linha) como o 'normal' (cf. Ibid, p. 173), já Roberts (que se apoia em Freedman) e Schökel listam o padrão 3:3 como o mais comum na PHB. (Cf. Roberts, 2001, p. 61; Schökel, 2000, p. 36)

Watson aponta essa inconsistência:

O mais notável aspecto da métrica hebraica quando descrita em termos acentuais (a parte dos diferentes caminhos de escanear dos estudiosos) é que nenhum único poema é consistentemente escrito em um padrão métrico. Até mesmo Lamentações não se utiliza da métrica qinah (3:2) por todo texto. ${ }^{245}$ (Watson, 1984, p. 98)

\subsubsection{SILÁBICO}

non-parallel couplets, there will often be found, consistently maintained, the same kind of rhythm as in those that are completely parallel."

244 "[...] is the most convincing to explain and listen to Hebrew poetic rhythm."

245 "The most noticeable aspect of Hebrew metre when described in accentual terms (aside from different ways of scanning by scholars) is that no single poem is consistently written in one metrical pattern. Even Lamentations does not use qinah (3:2) metre throughout." 
O verso silábico é medido pelo número de sílabas na linha, independente da quantidade ou acento. O sistema é mais inflexível e não prevê variações no número de sílabas fora do padrão métrico. (Cf. Vance, 1997, p. 189)

Freedman e Cross, os principais adeptos desse sistema, constroem sua argumentação a partir dos trabalhos de Ley, Budde e Sievers (cf. Ibid., p. 202), e, fazendo conexão com a poesia egípcia e mesopotâmica, em especial a ugarítica, eles afirmam haver uma regularidade considerável e acrescentam:

Essa regularidade repousa em algum lugar entre um simples acento métrico (isto é, pareando sílabas acentuadas sem considerar o número de sílabas não acentuadas), e uma complexa métrica envolvendo contagem de sílabas e divisão em pés métricos. ${ }^{246}$ (Cross e Freedman, 1975, p. 8-9)

Em outro momento, Freedman faz uma declaração clara:

Sem negar nem a importância da sílaba acentuada para determinar o ritmo, nem a possível aplicação de um mais preciso sistema quantitativo para o verso hebraico, somos persuadidos que as sílabas não-acentuadas desempenham um papel na poesia hebraica junto com a sílaba acentuada, e que contando o número total de sílabas nas linhas e em unidades maiores produz um quadro mais confiável da estrutura métrica do que qualquer outro procedimento agora em uso. ${ }^{247}$ (Freedman, 1980, p. 42)

Geller, que também acredita que o sistema métrico silábico é mais útil e funcional ao estudar a PHB, exibe uma reflexão que parece constante: "[...] está claro que a introdução da métrica abre a porta para incerteza adicional, a qual, claro, reflete nossa ignorância sobre a verdadeira natureza da métrica hebraica [...]". ${ }^{248}$ (Geller, 1979, p. 9)

\footnotetext{
246 "This regularity lies somewhere between a simple stress metre (i.e., matching accented syllables without regard to the number of unstressed syllables), and a complex meter involving syllable count and division into metrical feet."

247 "Without denying either the importance of stressed syllables for determining rhythm, or the possible application of a more precise quantitative system to Hebrew verse, we are persuaded that unstressed syllables played a role in Hebrew poetry along with stressed syllables, and that counting the total number of syllables in lines and larger units produces a more reliable picture of the metrical structure than any other procedure now in use."

248 "[...] it is clear that the introduction of meter opens the door to additional uncertainty, which, of course, reflects our ignorance of the true nature of Hebrew metrics [...]."
} 


\subsubsection{SINTÁTICO}

Uma das alternativas para o sistema métrico acentual é a aproximação sintática e O'Connor fez a mais "sofisticada" e extensiva tentativa de formulá-la. (Cf. Roberts, 2001, p. 65) Esse sistema métrico sintático consistiria, basicamente, de quatro aspectos: a ordem linear das palavras; a categorização morfológica das palavras em cada parte do discurso (linha); agrupamento das palavras em constituintes estruturais da sentença e; papel funcional da frase. (Cf. Cloete, 1989, p. 50)

Em primeiro lugar, O’Connor reconhecia que era impossível determinar a possível intenção do autor quanto à estrutura do verso e construiu seu método focando apenas o texto. (Cf. Leatherman, 1998, p. 99)

Sua postulação, entretanto, evita o uso do termo "métrica":

O elemento da estrutura do verso hebraico que Lowth acreditava estar totalmente perdido, ele chamava de métrica. Devemos argumentar que as regularidades que ele e seus sucessores observaram como fonológicas são, de fato, sintáticas. Descrições da relação entre cláusula e distribuição frasal e a forma da linha são mais precisas e dão conta de uma maior variedade de elementos do verso do que qualquer tratamento fonológico proposto. ${ }^{249}$ (O'Connor, 1980, p. 4)

Dessa afirmação, se deduz duas coisas principais: que O'Connor entendia que a sintaxe opera como um tipo de métrica poética; e que a sintaxe é a chave para a estrutura do verso hebraico. (Cf. Leatherman, 1998, p. 103) A posição de O'Connor fica mais clara na seguinte citação:

O sistema que descrevemos será da mesma espécie com uma métrica, a qual Lotz descreve como 'a regulação numérica de certas propriedades da forma linguística' do verso [...]. Nós

\footnotetext{
249 "The feature of Hebrew verse structure Lowth believed hopelessly lost he called meter. We shall argue that the regularities he and his successors have regarded as phonological are in fact syntatic. Descriptions of the relation between clause and phrase distribution and line shape are more precise and account for a wider range of features of the verse than any phonological treatment proposed."
} 
decidimos não chamar o sistema de métrica; nos referiremos aos seus componentes como restrições e ao todo como restritivo. ${ }^{250}$ (O'Connor, 1980, p. 67)

A afirmação de O'Connor é basicamente que o verso hebraico é regular e que a regularidade dele pode ser descrita sintaticamente, pela forma e medida das restrições em cada linha. (Cf. Leatherman, 1998, p. 105)

\subsubsection{NÃO HÁ MÉTRICA, HÁ PARALELISMO}

Kugel argumenta enfaticamente contra a ideia de métrica na PHB. Parte de sua argumentação é que os que primeiro atribuíram a ideia de métrica ao texto bíblico foram judeus helenizados e cristãos que falavam grego. Estes dois grupos, segundo ele, procuraram imputar à PHB a 'excelência' da poesia grega. (Cf. Kugel, 1981, p. 301) Uma de suas afirmações categóricas quanto ao tema é: "O coração da métrica essencial no hebraico é agora, e sempre foi, a suposição dos metricistas". ${ }^{251}$ (Cf. Ibid., p. 300)

Para ele, a busca constante e a diversidade de teorias apontam para um mesmo fim, o de que não existe métrica. Ao mesmo tempo, sugere que o "paralelismo é a única métrica da poesia bíblica", ${ }^{252}$ ressaltando que as ideias (paralelismo, poesia e métrica) devem ser entendidas de maneira não tradicional. (Cf. Ibid., p. 301)

Adele Berlin, de forma parecida a Kugel, aponta a falta de concordância em torno de um sistema métrico e as deficiências em manter o mesmo na análise de um grande número de textos. Ela afirma: "Parece melhor, portanto, abandonar a busca por métrica na poesia da Bíblia" ${ }^{253}$ (Berlin, 1996, p. 308), opinião compartilhada por Alter. (Cf. Alter, 1985, p. 9)

\footnotetext{
250 "The system we describe will be of the same sort as a meter, which Lotz defines as 'the numerical regulation of certain properties of the linguistic form' of verse [...]. We have decided not to call the system a meter; we shall refer to its components as constraints and to the whole as a constriction."

251 "The heart of the metrical crux in Hebrew is now, and always has been, the assumptions of the metricists."

${ }_{252}$ "parallelism is the only meter of biblical poetry."

253 "It seems best, therefore, to abandon the quest for meter in the poetry of the Bible."
} 
Entretanto, ainda que rejeite a ideia de métrica, Berlin reafirma 0 conceito de ritmo. Para ela a PHB apresenta certo ritmo, ainda que esse ritmo não esteja relacionado com medidas de regularidade. Esse ritmo é resultado da concisão das linhas paralelas, mas mais do que isso: "O número de pensamentos e, portanto, de palavras e acentos em cada linha de um paralelismo tendem a ser parecidos" ${ }^{254}$ (Berlin, 1996, p. 308) A conclusão de Berlin é: "Esse ritmo, um sub-produto do paralelismo, pode ser visto como o aspecto 'métrico' da poesia bíblica". ${ }^{255}$ (Berlin, 1996, p. 309)

Ainda nessa relação sobre ritmo e métrica, Petersen e Richards apontam as diferenças de uso dos dois conceitos. Enquanto a métrica provê uma unidade geral ao poema, o ritmo na PHB seria mais complexo e envolveria não só unidade, mas variação. Assim, ao invés de esperar uniformidade entre todas as linhas de um poema, como se esperaria do uso da métrica, o poema hebraico bíblico revela um delicado balanço entre regularidade e variação. $O$ resultado, segundo eles é que, ao ler PHB deve-se buscar a "regularidade e variedade rítmica, não previsibilidade métrica" ${ }^{256}$ (Petersen e Richards, 1992, p. 47)

Sem falar em ritmo, mas em uma crítica à busca por um padrão métrico, Meir Weiss escreveu:

A tendência em direção à esquematização pode ser vista nas várias rígidas teorias da métrica poética bíblica. Ao invés de nadar com a corrente do poema e ser elevado por suas ondas, estudiosos têm firmemente resistido a qualquer movimento do local de onde seus 'esquemas' têm os colocado - testifique as muitas emendas textuais metri causa. ${ }^{257}$ (Weiss, 1984, p. 242243)

Nota-se, pela argumentação dos autores citados, que há uma rejeição pela ideia de métrica fixa e elaborada, mas parece haver uma tendência em

\footnotetext{
254 "The number of thoughts and, therefore, of words and of stresses in each line of a parallelism tends to be about the same [...]."

255 "This rhythm, a by-product of parallelism, may be viewed as the 'metrical' aspect of biblical poetry."

256 "[...] rhythmic regularity and variety, not metric predictability."

257 "The tendency towards schematization may be seen in various rigid theories of Biblical poetic meter. Instead of swimming with the current of the poem and being lifted up its waves, scholars have firmly resisted any motion from the spot where their 'schemes' have placed them - witness the many textual emendations metri causa."
} 
entender a métrica como um produto do balanço ou ritmo produzido pelo paralelismo e sem uma lei organizacional rígida.

\subsection{Pares de PalaVRas}

Em seu texto sobre a PHB, Lowth chamava atenção para os termos aralelos, tanto palavras quanto sentenças (cf. Lowth, s/d, p. 204-205), mas foi com a descoberta das relações entre a poesia ugarítica e a hebraica que as primeiras tratativas sobre esses termos, ou pares de palavras paralelas, que apareciam frequentemente na $\mathrm{BH}$, começaram surgir. (Cf. Berlin, 1996, p. 305)

Ginsberg, em 1934, aponta que as semelhanças entre a poesia ugarítica e a hebraica vão além do paralelismo e contemplam algumas expressões que parecem fixas. Posteriormente, Cassuto apresenta, inclusive, uma lista de pares fixos de palavra apontando que o uso desse recurso seria fruto de uma espécie de convenção. (Cf. Yoder, 1971, p. 470-471)

A definição de um par de palavras 'tradicional' é quando quaisquer termos da mesma classe gramatical ocorrem em paralelo mais de uma vez. (Cf. Ibid., p. 472)

Listas de pares de palavras e suas ocorrências, tanto na poesia ugarítica, quanto na hebraica, são comuns em diversos trabalhos. (Cf. Yoder, 1971, p. 473-487; Watson, 1994, p. 262-312; Watson, 1984, p. 128-143; etc.) Exemplificando o que seria um par de palavras, os termos 'olhos' e 'coração' (לב e aparecem em paralelo em diversos textos, entre os quais os listados abaixo (cf. Watson, 1994, p. 285-287):

a) Is $44: 18$

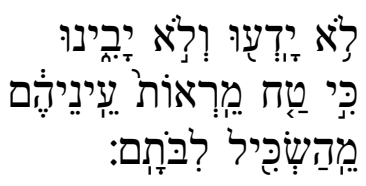

Não conhecem e não discernem, pois cobriu seus olhos para que não vissem 
seus corações para que não entendessem. ${ }^{258}$

b) Pv 4:21

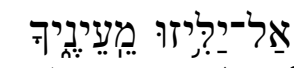

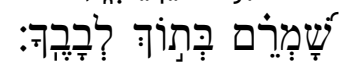

Não os deixem escapar dos teus olhos, mantenha-os dentro do teu coração. ${ }^{259}$

c) Ec $2: 10$

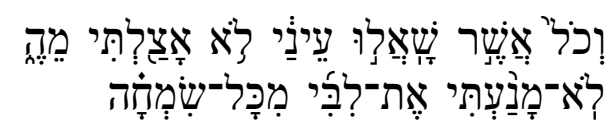

e tudo que buscaram meus olhos não afastei deles, não afastei do meu coração toda alegria. ${ }^{260}$

d) SI 131:1

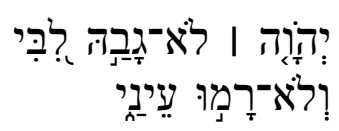

YHWH, não está elevado meu coração,

e não estão erguidos meus olhos ${ }^{261}$

e) Jó 15:12

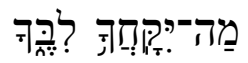

\footnotetext{
${ }^{258}$ A divisão em versos segue a sugestão de Watson. (1994, p. 285) Sua tradução do hebraico foi: "They do not know or understand / for too blinded are their eyes to see, / their hearts to perceive."

${ }^{259}$ A divisão em versos segue a sugestão de Watson. (1994, p. 286) Sua tradução do hebraico foi: "Do not let them (my words) deviate from your eyes, / keep them within your heart."

${ }^{260}$ A divisão em versos segue a sugestão de Watson. (1984, p. 286) Sua tradução do hebraico foi: "Everything my eyes demanded I did not refuse them, / I did not deny my heart any pleasure."

${ }^{261}$ A divisão em versos segue a sugestão de Watson. (1984, p. 287) Sua tradução do hebraico foi: "Yahweh / my heart is not haughty, / my eyes are not raised high."
} 
Por que te leva o teu coração?

E por que acendem os teus olhos? ${ }^{262}$

Esses termos, ou palavras, que ocorrem em paralelo estariam em um estoque. Ao compor seu poema, o poeta faria uso desses pares de palavras do estoque a fim de construir o paralelismo e tornar o poema mais acessível aos ouvintes. Essa ideia advém, principalmente, da teoria de que a PHB seria, primariamente, oral, e, por isso, recheada de fórmulas prontas. (Cf. Watson, 1984, p. 78-82; ${ }^{263}$ Berlin, 1985, p. 65-66; Watters, 1976, p. 117)

Essa abundância de pares de palavras no texto da $\mathrm{BH}$ levou os estudiosos a declararem que a PHB era uma edificação baseada em fórmulas e que as mesmas desempenhariam uma função equivalente à métrica na organização do poema. (Cf. Berlin, 1985, p. 66) Weiss explica:

\begin{abstract}
Esses critérios da crítica da forma para definir os vários gêneros literários estão baseados na suposição fundamental que as formas essenciais da literatura israelita evoluíram no estágio da tradição oral, já que a transmissão oral do assuntosujeito tradicional, baseada unicamente na memória, só teria sido possível se um certo esquema e formas de expressão estivessem aderidas à. ${ }^{264}$ (Weiss, 1984, p. 56)
\end{abstract}

Berlin sugere que 0 uso dos pares de palavras tem origem psicolinguística, especificamente na área focada no processo de associação de palavras. Assim, o uso dos pares de palavras seria nada mais do que o produto da normal associação de palavras feita por qualquer falante. (Cf. Berlin, 1985, p. 67)

Usualmente, certas palavras provocam a associação com um certo número de outras palavras. Por exemplo, quando se diz 'homem', a associação

\footnotetext{
${ }^{262}$ A divisão em versos segue a sugestão de Watson. (1984, p. 287) Sua tradução do hebraico foi: "Why is your heart enraged, / and why do your eyes blink?"

${ }^{263}$ Watson defende a hipótese de que a PHB tem origem oral e apresenta uma série de argumentos a favor dessa teoria, dentre os quais, os pares de palavras. (Cf. Watson, 1984, p. 66-86)

264 "These form-critical criteria for defining the various literary genres are based on the fundamental assumption that the essential forms of Israelite literature evolved at the stage of oral tradition, since oral transmission of traditional subject-matter, based solely on memory, would have been possible only if a certain schemata and forms of expression were adhered to."
} 
(resposta) mais comum é 'mulher', mas também, em menor número, 'menino'. Linguistas ranqueiam essas associações estatisticamente. Nesse caso, a associação de uma palavra com outra também evidencia o pano de fundo pessoal. (Cf. Ibid., p. 71)

O'Connor declara:

\begin{abstract}
O exercício psicoterapêutico de livre associação revela, se isso não é óbvio, que qualquer palavra em uma língua pode ser pareada com outra. Sem tomar em consideração a utilidade psicológica, o exercício vai provocar muitos complexos de palavra que estão relacionados com a estrutura do mundo como percebido através do meio da linguagem. ${ }^{265}$ (O'Connor, 1980, p. 96)
\end{abstract}

Ou seja, não há um "estoque" de pares de palavras ou fórmulas, mas uma associação normal de palavras que ocorre frequentemente e podem ser geradas por qualquer falante de uma língua: "todos os pares de palavras hebraicos - podem ser entendidos como produto da normal associação linguística". ${ }^{266}$ (Berlin, 1985, p. 68)

Sem se utilizar diretamente da nomenclatura "pares de palavras", ou explicar o fenômeno em termos de associação normal de palavras, Weiss também parece ser contrário à ideia de que a PHB fosse delimitada por palavras pareadas. Ele declara: "Finalmente, o poeta, combinando palavras para fazer a sentença, não as vê como símbolos inanimados, mas como criaturas vivas, que mantêm relações necessárias de atração e repulsão mútuas". ${ }^{267}$ (Weiss, 1984, p. 76) Weiss enfatiza que o intérprete da PHB não deve se prender a modos esquemáticos ao explicar as palavras pareadas, mas procurar o significado de cada uma e da combinação delas em cada poema especificamente. (Cf. Ibid., p. 76-77)

\footnotetext{
265 "The psychotherapeutic exercise of free association reveals, if it is not obvious, that any single word in a language can be paired with another. Irrespective of its psychological usefulness, the exercise will elicit many word complexes which are related to the structure of the world as it is perceived through the medium of language."

266 "[...] all Hebrew words pairs - can be understood as the product of normal linguistic association."

267 "Finally, the poet, combining words to make up a sentence, does not view them as inanimate symbols, but rather as living creatures, who maintain necessary relations of mutual attraction and repulsion."
} 
Melamed possui uma abordagem diferenciada ao alegar que os pares de palavras na PHB são, na verdade, um rompimento de estereótipos. Ele cita o

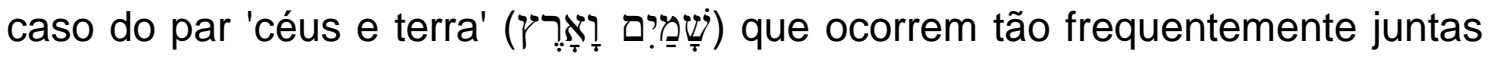
( $\mathrm{Gn}$ cerca de 30 vezes na $\mathrm{BH}$, como $\mathrm{Gn} 1: 1$; etc.), mas quando em textos poéticos, se separam, quebrando, ou adiando, o encontro do par. Deste modo, criam uma equivalência paralelística, como em Dt 32:1 (cf. Melamed, 1961, p. 140-142):

a) Gn $1: 1$

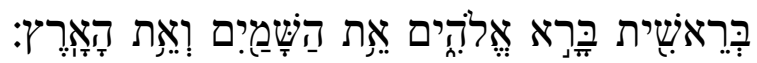

No princípio criou Deus os céus e a terra.

b) Dt $32: 1$

Dai ouvidos, céus, e eu falarei;

e escuta, terra, as palavras da minha boca.

A conclusão de Berlin e desse trabalho sobre o tópico, que parece ser partilhada também por Watson (cf. Watson, 1994, p. 268) é:

Não é o par de palavras que cria paralelismo. É o paralelismo que ativa pares de palavras. Já que paralelismo é essencialmente uma forma de projetar equivalências, ele produz equivalentes em todos os níveis linguísticos. ${ }^{268}$ (Berlin, 1985, p. 79)

\subsection{MetÁFora}

\footnotetext{
268 "It is not word pairs that create parallelism. It is parallelism that activates word pairs. Since parallelism is essentially a form of projecting equivalences, it produces equivalents on all linguistic levels."
} 
Poesia não é apenas verbal, mas também visual (cf. Salisbury, 2004, p. 4): "Em um sentido mais amplo, poesia é imagem". ${ }^{269}$ (Watson, 1984, p. 251) Uma imagem pode resumir o sentido do poema (cf. Ibid., p. 253) ou ser o fundamento sobre o qual o poema será construído, dando mais ênfase à mensagem do poeta. (Cf. Rogers, 2010, p. 16) Assim, um poeta que não vive em um ambiente rural pode, por exemplo, se utilizar de imagens agrícolas e rurais para escrever seu poema, afinal "a criação literária nunca é um mero registro de eventos". ${ }^{270}$ (Weiss, 1984, p. 52)

Como coloca Schökel: "Ambos, o leitor e o intérprete da Bíblia precisam despertar sua imaginação quando lerem ou estudarem poesia bíblica. O que foi escrito com imaginação, precisa também ser lido com imaginação". ${ }^{271}$ (Schökel, 2000, p. 104) A imagem, "talvez a essência da poesia" (Ibid., p. 95), conduz às seguintes reflexões:

a) O espírito humano experimenta a realidade através dos sentidos e então tenta transformar suas experiências em palavras descrevendo os objetos percebidos. A descrição pode ser detalhada e lenta, ou pode ser limitada a um par de bem escolhidas e decisivas características. b) O espírito humano passa por experiências, faz descobertas e estabelece relacionamentos entre diferentes coisas, achando harmonia e unidade na pluralidade do que vê. c) $A$ imaginação assume 0 controle da experiência e a transforma em um novo e coerente sistema. d) O espírito humano vai através do que pode ser percebido com os sentidos somente para ir além, ele penetra o que pode ser percebido para descobrir algo mais. e) O espírito humano procura a ajuda da experiência sensorial para se aproximar com ela de algo que é transcendente, de modo a expressar o que não pode ser expresso. ${ }^{272}$ (lbid.)

\footnotetext{
269 "In the larger sense, poetry is imagery [...]."

270 "[...] the literary creation is never a mere record of events."

271 "Both the reader and the interpreter of the Bible must alert their imagination when they read or study biblical poetry. What has been written with imagination, must also be read with imagination [...]."

272 "a) The human spirit experiences reality through the senses and then tries to transform its experiences into words by describing the objects perceived. The description may be detailed and leisurely, or it may be limited to a couple of well-chosen and decisive features. b) The human spirit undergoes experiences, makes discoveries and establishes relationships between different things, finding harmony and unity in the plurality it sees. c) The imagination takes over experience and transforms it into a new and coherent system. $d$ ) The human spirit goes through what can be perceived with the senses only to go beyond it, it penetrates what can be perceived in order to discover something more. e) The human spirit seeks the help of sense experience in order to approach with it something which is transcendent, in order to express what cannot be expressed."
} 
Berlin também argumenta que nenhuma discussão sobre PHB pode excluir a importância da imagem, ou metáfora, que é frequentemente tomada como a "essência da poesia". Ela declara: "Poesia enxerga o mundo metaforicamente; oferece uma maneira alternativa de ver a realidade". ${ }^{273}$ (Berlin, 2004, p. 2101)

A metáfora, palavra de origem grega, consiste em descrever ou apresentar uma realidade em termos que sugerem uma outra. Mas a definição de metáfora é motivo de grande discussão, sendo possível encontrar mais de cem abordagens diferentes do tema. Fundamentalmente, entretanto, a metáfora funciona de maneira semelhante ao paralelismo, pois cria um relacionamento entre palavras, frases, linhas, etc., estabelecendo equivalência através da justaposição de imagens. (cf. Rogers, 2010, p. 12) Por isso, é dito que a metáfora e o paralelismo são duas faces da mesma moeda (Ibid., p. 82)

Esse relacionamento entre paralelismo e metáfora é de tal alcance que "linhas paralelas sempre têm o potencial de serem entendidas metaforicamente - essa é a natureza do paralelismo". ${ }^{274}$ (Berlin, 1985, p. 100) Ou seja, de certa forma, "a metáfora é a forma básica do paralelismo". ${ }^{275}$ (Landy, 1984, p. 80)

Então, assim como o paralelismo, a metáfora é composta de dois elementos principais, que podem ser chamados de 'teor' e 'veículo'. (Cf. Long, 1993, p. 1) Logo, em SI 23:1 (cf. Rogers, 2010, p. 13), YHWH (יהוה) é o 'teor' e "meu pastor" (רְּצִ é o 'veículo. Em outras palavras, o sujeito principal é YHWH e o sujeito secundário é "meu pastor", ou ainda, o foco é YHWH e o quadro é "meu pastor". (Cf. Long, 1993, p. 1-2)

Antes de prosseguir, é necessário indicar que a diferenciação feita entre metáfora e símile, sendo a segunda uma espécie de comparação direta, com o uso de preposições comparativas ('como', etc.), não é tão clara no hebraico bíblico, visto que as preposições inseparáveis são, por vezes, omitidas. Há,

\footnotetext{
273 "Poetry envisions the world metaphorically; it offers an alternative way of seeing reality." 274 "Parallel lines always have the potential to be understood metaphorically - this is the nature of parallelism [...]."

${ }_{275}$ "[...] the basic form of parallelism is metaphor."
} 
portanto, uma coincidência entre ambas. (Cf. Salisbury, 2004, p. 16; Rogers, 2010, p. 13)

Abaixo apresentamos uma série de exemplos de metáfora funcionando lado a lado com o paralelismo:

a) Pv 26:9 (cf. Berlin, 1985, p. 100)

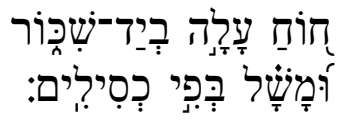

como galho que ascende nas mãos do bêbado, é um provérbio na boca dos tolos. ${ }^{276}$

b) Ec 7:1 (cf. Ibid., p. 101)

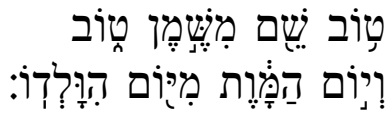

bom nome é melhor que óleo bom,

e o dia da morte do que o dia do seu nascimento. ${ }^{277}$

c) SI 52:6 (cf. Schökel, 2000, p. 108)

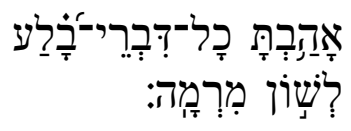

Tu amas todas as palavras que devoram, língua enganosa.

d) SI 52:10 278 (cf. Wendland e Zogbo, 2000, p. 43)

\footnotetext{
${ }^{276}$ A divisão em versos segue a sugestão de Berlin. (1985, p. 100) Sua tradução do hebraico foi: "A thorn comes to the hand of a drunkard; / And a proverb to the mouth of fools."

${ }^{277}$ A divisão em versos segue a sugestão de Berlin. (1985, p. 101) Sua tradução do hebraico foi: "Better a name than good oil; / And one's death-day than one's birth-day."

${ }^{278} \mathrm{Na}$ ARA, SI 52:8.
} 
e eu sou como uma árvore de azeitona verde, na casa de Deus. ${ }^{279}$

e) SI 18:3 (cf. Watson, 1984, p. 265)

YHWH minha rocha e meu forte,

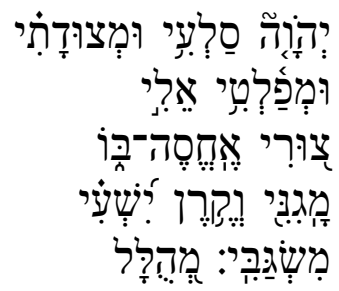

e meu salvador meu Deus,

minha rocha em quem me refugio,

meu escudo e o chifre da minha salvação

meu baluarte que é digno de louvor . ${ }^{280}$

Benjamin Harshav ${ }^{281}$ oferece algumas noções importantes para eliminar certas pré-concepções sobre metáfora. Uma delas é que a metáfora não pode ser limitada a uma palavra, ou sentença. (Cf. Harshav, 2007, p. 33) Ele diz:

Se uma metáfora é uma relação entre dois termos, qualquer desses termos pode cobrir muito mais do que uma palavra em um texto. É, frequentemente, uma relação sem limite definido ao invés de uma unidade fixa. Uma sentença inteira pode ser literal quando lida independentemente e tornar-se metafórica em seu contexto mais amplo. [...] O ponto é que metáfora não é uma unidade linguística, mas um padrão textual-semântico [...]. ${ }^{282}$ (Ibid., p. 34)

A colocação de Harshav demonstra-se relevante especialmente quando se tem em vista o livro de Cântico dos Cânticos, como enfatiza LaCocque: "O Cântico dos Cânticos é amplamente metafórico". ${ }^{283}$ (Cf. LaCocque, 1998, p. 24)

\footnotetext{
${ }^{279}$ A divisão em versos segue a sugestão de Zogbo e Wendland. (2000, p. 43) Sua tradução do hebraico foi: "But I am like a green olive tree / in the house of God."

${ }^{280}$ A divisão em versos segue a sugestão de Watson. (1984, p. 265) Sua tradução do hebraico foi: "Yahweh is my rock and my fortress, / my God is my haven, / my mountain where I take refuge; / my shield and my saving horn, / my stronghold, worthy of praise."

${ }_{281}$ Antigamente, Hrushovski. (Cf. Alter, 2011, p. 227)

282 "If a metaphor is a two-term relation, any of its terms may cover much more than a word in a text. It is often an open-ended relation rather than a fixed unit. A whole sentence may be literal when read independently and become metaphorical in its wider context. [...] The point is that metaphor is not a linguistic unit but a text-semantic pattern [...]."

283 "The Song of Songs is largely metaphorical."
} 
Alter também ressalta isso: "[...] a beleza distintiva de Cântico dos Cânticos é a elaboração extravagante da metáfora [...]". ${ }^{284}$ (Alter, 1985, p. 196) $)^{285}$

A conclusão é que a metáfora é de importância destacada, assim como o paralelismo, na análise da PHB e, em especial, de CdC.

\subsection{PRINCíPIO GeRAL: TENSÃo}

Daniel Grossberg apresenta uma nomenclatura física para descrever um princípio geral da poesia: a tensão entre forças centrífugas e centrípetas. Em cada poesia existem elementos de unidade (força centrípeta) e de descontinuidade (força centrífuga). O poeta se utiliza dessas 'forças' para criar complexidade, beleza e dinâmica. No extremo centrípeto estão todos os recursos poéticos que criam unidade textual, coesão ou progressão. E no extremo centrífugo estão todos os recursos poéticos que criam descontinuidade, segmentação e divisão. (Cf. Grossberg, 1989, p. 5-7)

Grossberg, entretanto, não busca dividir os elementos poéticos nas duas categorias, ou seja, os que unem e os que provocam quebra no texto. $\mathrm{Na}$ verdade, segundo ele, os elementos, após identificados, precisam ser analisados sob a ótica de seu efeito na estrutura do poema. (Cf. Ibid., p. 8)

Ao aplicar seu conceito sobre o livro de CdC, Grossberg deduz que, "muitas das mesmas forças para a unidade são, paradoxalmente, forças para a desunidade também", ${ }^{286}$ o que, talvez, segundo ele, explique as diferentes conclusões sobre a estrutura de CdC entre os estudiosos. (Cf. Ibid., p. 14)

Watson, em uma revisão sobre abordagens posteriores a publicação do seu 'manual' de PHB (Classical Hebrew Poetry), aponta que abordagens estéticas levando em conta a obra poética como um todo e não apenas identificando elementos são importantes. Essas abordagens estéticas, segundo

284 "[...] the distinctive beauty of the Song of Songs is the flamboyant elaboration of the metaphor [...]."

${ }^{285}$ Long, em sua tese doutoral, lista a ocorrência de 52 símiles e 153 metáforas. (Cf. Long, 1993, p. 108, 328)

286 "[...] many of the same forces for unity are paradoxically forces for disunity as well." 
Watson, não deixam de lado os elementos poéticos, mas os estudam a partir de seu efeito coesivo no texto. Ele cita nominalmente o trabalho de Grossberg como um exemplo dessa abordagem mais ampla. (Cf. Watson, 1993, p. 375376)

Salisbury, ao invés dos termos físicos, trata das forças de continuidade e descontinuidade. Haveria dois tipos de continuidade: coesão e progressão. Coesão seria composta de elementos poéticos que unem o texto (repetição, inclusão, etc.). Já progressão é quando um tema, pensamento ou evento perpassa a linha principal e encharca o poema. Também haveria dois tipos de descontinuidade: segmentação e proeminência. O primeiro, segmentação, descreveria a força que quebra o texto em partes e sub-unidades (mudança geográfica, mudança de personagem, etc.). A segmentação na fluidez do texto poético pode, justamente, apontar para a seção proeminente, ou pico temático do poema. (Cf. Salisbury, 2004, p. 5)

Todo poema seria construído sobre a utilização da regularidade e da variação, ou seja, as duas forças (ou o princípio de oposição) estariam constantemente trabalhando em todos os níveis da obra poética: "Os poetas hebreus usam combinações únicas de uniformidade e diferença para enfatizar seu ponto. Quando padrões regulares são interrompidos, o leitor/ouvinte sabe que é hora de prestar atenção especial". ${ }^{287}$ (Ibid.)

A conclusão é que a PHB está alicerçada nesta tensão e a análise da mesma deve ter em conta este princípio geral, pois qualquer tipo de quebra de gênero, número, etc., pode ser intencional. (Cf. Dorsey, 1999, p. 21-22)

\section{Capítulo 4}

287 "Hebrew poets use unique combinations of sameness and difference to emphasize their point. When regular patterns are interrupted, the reader/hearer knows it is time to pay special attention." 


\section{Elementos Pó́ticos Diversos}

A PHB abriga uma série de outros elementos poéticos significativos que, embora não desempenhem um papel tão distintivo, demonstram a habilidade do poeta e, em certos casos, podem ser determinantes na estruturação de um poema. (Cf. Salisbury, 2004, p. 5)

\subsection{LiNHA, BicóLON E ESTROFE}

A unidade básica da poesia é a linha, também chamada de cólon, mas não em raras ocasiões o poeta pode balancear as duas metades da linha em paralelismo interno. As linhas são costumeiramente costuradas em pares, ao que se dá o nome de bicólon, mas monocólon (linha isolada e semiindependente), tricólon (costura de três linhas) ou tetracólon (quatro linhas) também aparecem. ${ }^{288}$ (Cf. Watson, 1984, p. 11-15)

Estrofes são unidades maiores do poema, compostas da junção das unidades menores, os bicólons. Elas são grupos de linhas poéticas ligadas por um tema comum, significado ou estrutura. Em algumas definições, entretanto, muitos estudiosos igualam as estrofes aos bicólons (ou tricólons, etc.), ou se utilizam de outra nomenclatura, como stanza, o que torna a definição dos termos controversa. ${ }^{289}$ (Cf. Ibid., p. 160-163)

Um exemplo de estrofe está no SI 121 (cf. Wendland e Zogbo, 2000, p. 53-54):

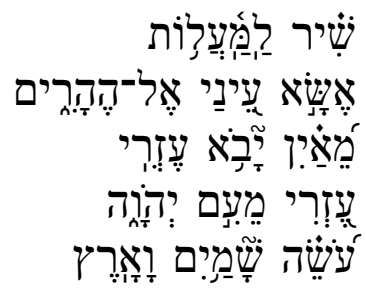

\footnotetext{
${ }^{288}$ Existem diversas técnicas para apontar a divisão em linhas, ou cólons. Além dessas diferentes técnicas, as nomenclaturas também divergem de autor para autor. Ver, entre outros, Korpel e De Moor (1988, p. 1-61); O'Connor (1980, p. 297-360).

${ }_{289}$ Para uma discussão detalhada sobre a nomenclatura e o uso na PHB e em outras línguas (ugarítico e acadiano), ver Watson (1984, p. 160-188).
} 


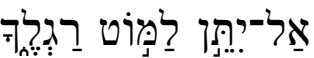

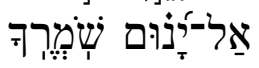

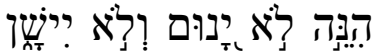

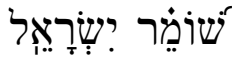

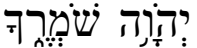

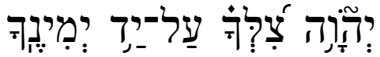

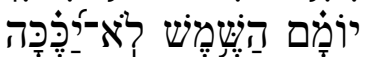

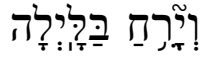

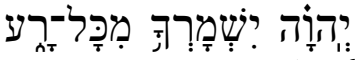

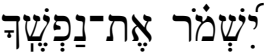

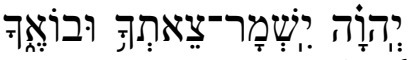

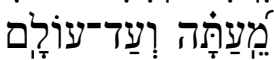

Cântico de subida:

Ergo meus olhos para os montes

de onde vem o meu socorro.

Meu socorro vem de YHWH,

fazedor dos céus e da terra.

Não deixará que vacilem teus pés, não cochilará aquele que te guarda.

Eis que não cochila nem dorme

o guarda de Israel.

YHWH é teu guardador,

YHWH é tua sombra sobre tua mão direita.

Pelo dia o sol não te castigará

e a lua a noite.

YHWH te guardará de todo o mal, ele guardará tua alma.

YHWH guardará tua saída e tua entrada,

desde esse tempo até o sempre. ${ }^{290}$

No salmo em questão, de acordo com Wendland e Zogbo, a primeira das quarto estrofes é formada pelos primeiros dois versículos, que estão unidos pela palavra-chave 'socorro'. Já a segunda estrofe também é formada por dois versículos unidos pelo tema de YHWH como guardador e com as palavras-chave 'dormir' e 'cochilar'. A terceira estrofe introduz YHWH como agente direto e o segundo bicólon é uma especificação do primeiro. A última

${ }^{290}$ A divisão dos versos e estrofes segue a sugestão de Wendland e Zogbo. (2000, p. 53-54) 
estrofe enfatiza a ideia da proteção divina e o segundo bicólon expande a promessa do primeiro bicólon dessa estrofe. (Cf. Ibid., p. 54)

O exemplo acima e a divisão de Wendland e Zogbo demonstram que a divisão de estrofes é, sobretudo, semântica. Segundo Paul Raabe, a estrutura superficial e o conteúdo semântico não podem ser divorciados um do outro. (Cf. Raabe, 1990, p. 183) Sobre isso Watson escreve:

É geralmente concordado que (a) a divisão em estrofe tende a ser baseada no conteúdo, (b) que há certos marcadores de estrofe mostrando quando as estrofes começam e/ou terminam e (c) não há regras duras ou rápidas que possam ser aplicadas. É, em certa extensão, uma questão de sentir. ${ }^{291}$ (Watson, 1984, p. 163)

\subsection{ACRóstico}

Um elemento estrutural de fácil reconhecimento. Quando uma série de linhas ou estrofes cujas letras iniciais formam o alfabeto Hebraico. Por exemplo, SI 25, 34, 37, 11, 112, 119, 145, Pv 31:10-31, Na 1:2-8 (meio acróstico) ou os quatro capítulos do livro de Lamentações. No SI 119 cada estrofe não somente é iniciada por uma das letras do alfabeto hebraico em sequência, mas é também composta de oito linhas e cada uma delas começa com a mesma letra do alfabeto. (Cf. Ibid., 192-195)

\subsection{Refrão}

O refrão é um subtipo do paralelismo, onde uma unidade textual (palavra-chave, linha ou mesmo uma estrofe inteira) é repetida ao longo do poema, servindo como marcação textual. (Cf. Ibid., p. 295) Serve para enfatizar uma ideia, como no SI 136:

\footnotetext{
291 "It is generally agreed that (a) stanza division tends to be based on content, (b) that there are certain stanza-markers showing where stanzas begin and/or end and (c) there are no hard and fast rules which can be applied. It is, to some extent, a matter of feel."
} 
Louvai a YHWH pois é bom, pois para sempre é Sua misericórdia. Louvai o Deus dos deuses, pois para sempre é Sua misericórdia. Louvai o Senhor dos senhores, pois para sempre é Sua misericórdia. ${ }^{292}$

Também pode ser utilizada ao mesmo tempo como fator de unidade/coesão textual e segmentação do texto, como em Ct 2:16 (cf. Ibid., p. 296):

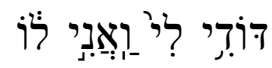

Meu amado é meu e eu sou dele.

O refrão acima acontece de maneira invertida em Ct 6:3:

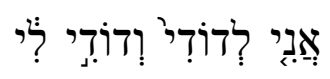

Eu sou do meu amado e meu amado é meu.

E mais uma vez, de maneira abreviada, em Ct 7:11:

Eu sou do meu amado.

\subsection{INCLUSÃO}

Também um subtipo do paralelismo, mas diferente do refrão, se repete apenas duas vezes, marcando início e final de estrofe. A inclusão, também

${ }^{292}$ Colocamos apenas os três primeiros versículos para ilustrar (SI 136:1-3). 
chamada de paralelismo envelope, é a repetição de uma palavra, conceito ou grupo de palavras no início e no final de uma unidade poética. Geralmente, as mesmas palavras são repetidas nas extremidades causando uma sensação de déjà-vu. Este recurso facilita a estruturação do poema na medida em que representa uma quebra de seção. (Cf. Ibid., p. 282-283)

Ct 2:10-13 contém um paralelismo envelope que exemplifica bem o que é o fato. Ali, o possível tricólon abaixo é repetido na abertura e no fechamento do convite do amado para a amada (cf. Ibid., p. 368):

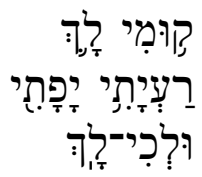

Levanta-te

minha amada, minha bela

e venha ${ }^{293}$

Schökel também aponta que o recurso da inclusão é uma técnica frequente para "marcar os limites do poema" e acrescenta que é fortalecido quando mais do que apenas uma palavra é repetida (cf. Schökel, 2000, p. 78), como no exemplo acima.

\subsection{ELIPSE}

Elipse é a omissão de uma partícula, palavra ou mesmo grupo de palavras de uma unidade textual aonde sua presença era esperada. 0 contexto, ao mesmo tempo que demanda sua presença, supre sua ausência como em Os 5:8, onde o verbo "tocar" (תקע) está ausente da segunda linha do par, mas sua presença fica implícita (cf. Watson, 1984, p. 304):

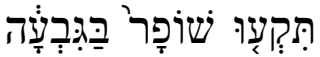

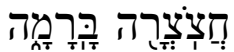

\footnotetext{
${ }^{293}$ A divisão em versos segue a sugestão de Watson (1984, p. 368). Sua tradução do hebraico
} foi:"Up now / my pretty darling, / come on!" 
Frequentemente o termo omitido da segunda linha do par é o verbo e por isso o a elipse também é chamada de 'supressão do verbo'. Sua intenção é adicionar concisão ao poema e criar uma variação do paralelismo. (Cf. Salisbury, 2004, p. 12)

\subsubsection{ELIPSE RÍtMicA ${ }^{295}$}

Um tipo de variação da elipse. Ocorre quando uma palavra ou frase é omitida da segunda linha do par, mas outra é acrescentada para manutenção de um certo ritmo e de um balanço entre as linhas. Por exemplo, em Pv 6:5 o verbo da primeira linha é omitido na segunda, mas um substantivo é acrescentado (cf. Ibid., p. 12):

Salva-te como uma gazela da mão como o pássaro da mão do caçador. ${ }^{296}$

\subsection{Aliteração 297}

\footnotetext{
${ }^{294}$ A divisão em versos segue a sugestão de Watson (1984, p. 304). Sua tradução do hebraico foi: "Bolw the trumpet in Gibeah, / the horn in Ramah."

${ }^{295}$ Galbraith aponta o uso dessa variante da elipse como uma prova do distanciamento da PHB dos modelos antigos de poesia, já que a poesia ugarítica, por exemplo, não apresenta esse tipo de recurso. (Cf. Galbraith, 1981, p. 168)

${ }^{296}$ A divisão em versos segue a sugestão de Salisbury (12). Sua tradução do Hebraico foi: "Save-yourself like a gazelle from the hand, / like a bird form the hand of the fowler."

${ }^{297}$ Adele Berlin e Patrick Hunt preferem o uso do termo consonância. (Berlin, 1985, p. 103-104; Hunt, 2008, p. 62)
} 
Uma repetição proposital da mesma consoante ou de consoantes de som similar. (Cf. Ibid., p. 13) Seu uso é frequente na PHB e ocorre, geralmente, em trechos pequenos e não se limita às consoantes do início de uma palavra, como em Ct 1:1, aonde o som do $ש$ se repete e o do 7 também (cf. Wendland e Zogbo, 2000, p. 37):

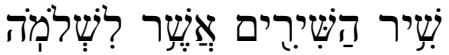

Cântico dos cânticos que é de Salomão.

Em alguns casos, a repetição do som se dá ao longo de um trecho maior e visa criar coesão, o que, por vezes, chega a ser uma rima, como em Êx 15:12-13 (cf. Alter, 1985, p. 53):

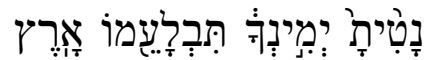

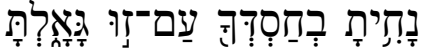

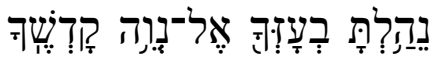

Tu estendeste Tua mão direita, engoliu-os a terra.

Tu conduziste na Tua misericórdia, povo que Tu resgataste.

Tu escoltaste na Tua força para a morada da Tua santidade. ${ }^{298}$

Nesse caso, a terminação de segunda pessoa masculino singular cria uma aliteração com a consoante palatal $\supset$ (na forma final) que se aproxima do efeito da rima, mas nesse caso também há a repetição das consoantes guturais $\pi$ e $\pi$, que acentuam, de alguma maneira, o som de $\supset .{ }^{299}$ Além disso, há uma aliteração das dentais $\Omega$ e $7^{300}$

\subsection{ASSONÂNCIA}

\footnotetext{
${ }^{298}$ A divisão em versos segue a sugestão de Alter (1985, p. 51). Sua tradução do hebraico foi: "You stretched out Your hand; the earth swallowed them.// You led in Your kindness; the people You redeemed.// You guided them in Your strength; to Your holy abode."

299 Greenberg aponta que o falante não-oriental não faz distinção entre $\pi$ e ว. (Greenberg, 1965 , p. 12) Na gramática de Joüon e Muraoka é indicada a similaridade do som de ambas. (Joüon e Muraoka, 2009, p. 25)

300 Para classificação das consoantes usadas nesse trabalho, consultar Blau (2010, p. 63-69).
} 
Similar à aliteração, é definida pela repetição de vogais. Ocorre quando uma série de palavras contém um "distintivo som vocálico" ou uma sequência específica desses sons. Mas, como há uma certa relação entre vogais e consoantes (as terminações masculinas e femininas, por exemplo), acaba por ocorrer uma sobreposição entre assonância e aliteração. (Cf. Watson, 1984, p. 222-223)

O exemplo anterior, de Êx 15:12-13, explicita isso, já que há uma ênfase no uso do qamáts gadól ${ }^{301}$, além da sequência vocálica nas duas primeiras palavras das duas primeiras linhas: qamáts gadól - riríq gadól - qamáts gadól. (Cf. Alter, 1985, p. 53)

Adele Berlin, no entanto, argumenta que o papel das vogais na construção do texto hebraico é totalmente secundário, se tiver algum. Ela também ressalta que o texto hebraico bíblico não possuía vogais e que, por isso, era conhecido como uma língua consonantal. (Cf. Berlin, 1985, p. 104) Revell também pondera sobre as incertezas da vocalização, mas alega não haver motivos suficientes para desconsiderar a existente. (Cf. Revell, 1981, p. 197-198)

Em todo caso, a própria leitura e análise do texto em estudo apontará se a assonância é um elemento proeminente e determinante para a construção do poema ou apenas um recurso estilístico (cf. Wendland e Zogbo, 2000, p. 39), como no exemplo mencionado acima.

\subsection{RIMA}

Uma palavra rima com a outra quando as duas soam iguais, quer dizer, quando há identidade sonora. Essa identidade pode apresentar diversos níveis. Esse recurso, no entanto, não é frequente na PHB. (Cf. Watson, 1984, p. 229; Wendland e Zogbo, 2000, p. 39; Salisbury, 2004, p. 14)

O mesmo exemplo de Êx 15:12-13 citado acima é um caso de rima (cf. Alter, 1985, p. 53):

301 Transliteração vocálica conforme proposta em Kirshbaum et al (2009, p.19). 


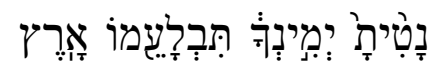

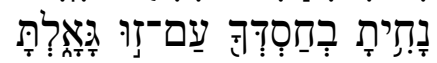

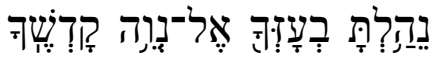

Tu estendeste Tua mão direita, engoliu-os a terra.

Tu conduziste na Tua misericórdia, povo que Tu resgataste.

Tu escoltaste na Tua força para a morada da Tua santidade. ${ }^{302}$

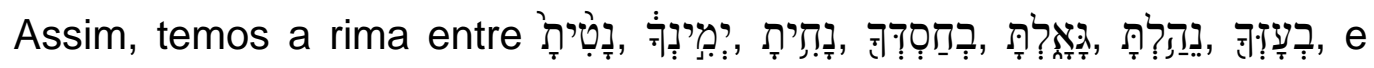

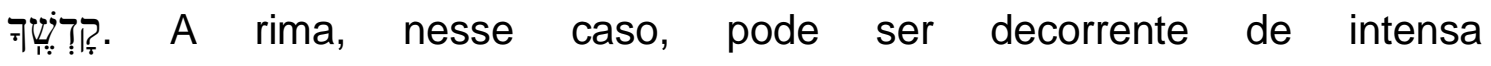
aliteração/assonância ou pode ser o inverso, ou seja, a busca pela rima gerou a aliteração e a assonância presentes aqui. Schökel, entretanto, descreve esse tipo de rima, feita por morfemas, como uma rima pobre e considera que a rima rica é muito rara em hebraico. (Cf. Schökel, 2000, p. 23)

\subsection{ONOMATOPEIA}

Segundo Watson, onomatopeia "pode ser definida como a imitação de um som dentro das regras da linguagem". ${ }^{303}$ (Cf. Watson, 19884, p. 234) Ele ainda menciona que cada língua tem suas próprias palavras que imitam sons e que acabam sendo exploradas na literatura, incluindo poesia. (Cf. Ibid.)

Schökel parece definir quase da mesma maneira, dizendo: "é a imitação de um som usando as qualidades fônicas de uma língua". ${ }^{304}$ (Schökel, 2000, p. 26) Essa imitação visa intensificar a imagem poética, relacionando o som e 0 sentido no quadro pintado pelo poeta. (Cf. Salisbury, 2004, p. 14)

Um caso onomatopaico é encontrado em Cântico dos Cânticos 1:2, na primeira parte do verso (cf. Hunt, 2008, p. 62):

\footnotetext{
302 A divisão em versos segue a sugestão de Alter (1985, p. 51). Sua tradução do hebraico foi: "You stretched out Your hand; the earth swallowed them.// You led in Your kindness; the people You redeemed.// You guided them in Your strength; to Your holy abode."

303 "[...] can be defined as the imitation of a sound within the rules of the language [...]".

304 "is an imitation of a sound using the phonic qualities of a language".
} 
Ele me beija com os beijos de sua boca.

No verso em questão, o uso de consoantes bilabiais (๖ e $\Xi$ ), uma consoante sibilante (ש) e uma uvular explosiva (ק) dão a sensação de reprodução do barulho de um beijo. (Cf. Ibid.) Apesar de a construção acima se utilizar de mais de uma palavra para dar a sensação do som de um beijo, em outras partes de Cântico dos Cânticos nota-se o uso do que seria uma onomatopeia regular (uma palavra reproduzindo um som). Em 2:8 o poeta utiliza o particípio pi el de para, sonoramente, criar a sensação de saltar, já que entre uma consoante líquida (מ) e uma sibilante (צ), ele coloca duas explosivas ( $\fallingdotseq$ e $\Xi$ ), justamente como se descrevesse, sonoramente, um salto. (Cf. Ibid., p. 63)

\subsection{Jogo de PALAVRAS}

A ambiguidade fonética, gramatical e lexical das palavras demonstra sua polivalência e é nela que se baseia o jogo de palavras. A polivalência pode ser de dois tipos: homônima e polissêmica. O tipo homônimo ocorre quando há uma identidade sonora, ou mesmo similaridade na raiz, mas diferença de significados. Já o tipo polissêmico implica que a mesma palavra pode ter diversos significados. (Cf. Watson, 1984, p. 237)

O jogo de palavras polissêmico, ou polissemia, também recebe o nome de paralelismo Janus e como já foi visto anteriormente nesse trabalho, não será analisado aqui. Já o jogo de palavras homônimas é chamado, por alguns, como paranomasia ${ }^{305}$, ou trocadilho, ou ainda, paralelismo sonoro. (Cf. Hunt, 2008, p. 37-40; Watson, 1984, p. 238)

Por exemplo, Jó 3, no final do verso 22 e no início do verso 23, apresenta um jogo de palavras que demonstra a polivalência homônima: 0

\footnotetext{
${ }^{305}$ Schökel usa o termo paranomasia para se referir ao jogo de palavras envolvendo nomes próprios, mas parece ser o único a fazer isso. (Cf. Schökel, 2000, p. 30)
} 
poeta usa קָָָּר (cova) no final de um verso e começa o próximo verso com (homem). (Cf. Alter, 1985, p. 77-78) Em Cântico dos Cânticos 4:11 há um jogo de palavras interessante entre o substantivo נפת (mel) e o verbo נטף (pingar; destilar), que aponta não só um paralelismo sonoro, como também uma aliteração, o que é frequente em se tratando desse recurso poético. (Cf. Hunt, 2008, p. 39)

\subsection{Metonímia}

O uso de um paralelismo, sutil, de sinônimos (cf. Schökel, 2000, p. 69) em que uma palavra é substituída por outra, mas continua subentendida (cf. Hunt, 2008, p. 37), como em Cântico dos Cânticos 7:6, onde o substantivo tranças (רהטים) é usado, mas a ideia é de algemas. No Salmo 46:10 uma série de substantivos são usados em paralelo, como sinônimos de guerra (מלחמוֹת): arco (קשת)), lança (ענית) e carruagens (עגלוֹת). (Cf. Salisbury, 2004, p. 17)

\subsection{SinÉDOQUE}

Quando uma parte representa o todo, ou seja, "onde o texto sugere a totalidade" focando em apenas uma ou mais partes dessa totalidade sem, contudo, se referir à sua completude. (Cf. Hunt, 2008, p. 57) O uso da sinédoque é interessante por revelar a parte que representa o todo, mas também por manter o todo oculto, ou seja, o que está ausente do texto é o mais importante, mas ao mesmo tempo a parte que o faz presente o contém, de certa forma. (Cf. Ibid., p. 58)

Portanto, no caso que parece mais simples, partes do corpo podem se referir ao corpo inteiro, como em Provérbios 23:15, onde coração (לב) é, claramente, parte do todo. Há ainda os casos em que o nome de uma cidade se refere a todos seus habitantes ou ao país, como em Ec 1:1, onde Jerusalém 
é uma sinédoque de Israel, o que fica claro em Ec 1:12. (Cf. Salisbury, 2004, p. 17)

\subsection{Merisma}

Quando a totalidade é expressa em apenas duas de suas partes limítrofes e que podem ou não ser 'opostos polares'. (Cf. Ibid.) O aspecto binário é importante, pois o merisma é uma espécie de divisão do todo em duas partes. (Cf. Schökel, 2000, p. 83) O merisma, como a sinédoque, é uma forma de mencionar o todo sem mencioná-lo. (Cf. Watson, 1984, p. 321)

O SI 121:6 possui dois merismas - dia e noite, sol e lua - como vemos:

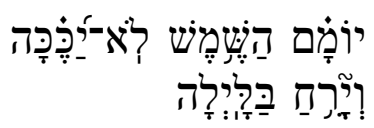

Pelo dia o sol não te castigará e a lua a noite.

O uso dos merismas pelo poeta visa afirmar e reafirmar a proteção de YHWH em todos os momentos diários. Aqui, os merismas são enfatizados pela elipse do verbo.

Outro, dentre diversos casos, é o de ls 1:6, na primeira parte do verso, onde lemos (cf. Watson, 1984, p. 321):

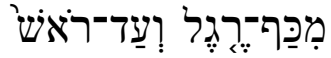

da sola do pé até a cabeça

\subsection{Personificação ou Prosopopeia}

Uma atribuição é feita, imbuindo de personalidade algo que é impessoal, ou seja, uma figura de linguagem em que coisas inanimadas são representadas ou ditas como se fossem pessoas. (Cf. Hunt, 2008, p. 50-51) Schökel é mais específico e prefere se referir à personificação quando 
tratando-se de qualidade abstrata agindo como ser humano. (Cf. Schökel, 2000, p. 123)

Alguns usos da personificação acabam sendo usados em largas porções, como a mulher-sabedoria e a mulher-estúpida no livro de Provérbios. (Cf. Salisbury, 2004, p. 18) No SI 85:11 a misericórdia (חסד) e a fidelidade (אמת) se encontram, e a justiça (צדק) e a paz (שלוֹם) se beijam. (Cf. Schökel, 2000, p. 123) Já em Ct 1:6 o sol parece ter a iniciativa de queimar a personagem feminina e, em certo sentido, também pode ser entendido como um antropomorfismo (cf. Hunt, 2008, p. 51):

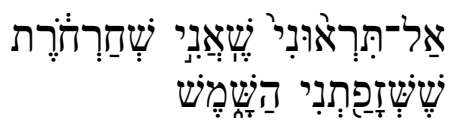

Não me olhes, pois estou morena, pois queimou-me o sol.

A personificação dentro do estudo da PHB e no restante do texto bíblico apresenta dificuldades, visto que parece estar presente constantemente. Schökel, ao mesmo tempo em que alerta para essa realidade, admite que com a ausência de critérios claros e objetivos, "é melhor exagerar o número de personificações do que subestimá-las". ${ }^{306}$ (Schökel, 2000, p. 124)

\subsection{ANTROPOMORFISMO}

Schökel coloca da seguinte forma: "Poesia bíblica é basicamente poesia religiosa. Ela fala sobre Deus através da experiência humana de Deus. [...] Em um sentido amplo, tudo que nós dizemos sobre Deus é antropomorfismo, pois humaniza Deus". ${ }^{307}$ (Ibid., p. 128) Assim, embora se coloque diferenças entre personificação e antropomorfismo, a sugestão é que se use o segundo para os casos que se referem a divindade. (Cf. Salisbury, 2004, p. 18)

\footnotetext{
306 "[...] it is better to exaggerate the number of personification than to underestimate them." 307 "Biblical poetry is basically religious poetry. It speaks of God through the human experience of God. [...] In the broad sense everything we say about God is anthropomorphism, for it humanizes God."
} 
No SI 98:1 temos um dos inúmeros exemplos em que a divindade é descrita com traços humanos, no caso com mão (direita) e braço (cf. Wendland e Zogbo, 2000, p. 44):

Salmo, cantai a YHWH um cântico novo,

pois maravilhas Ele fez, trouxe auxílio para Ele Sua mão direita e o braço da Sua santidade.

Em outra passagem, SI 78:65, a dividande, de quem é dito que não dorme (SI 121:4), desperta do sono como um homem forte que quer beber (cf. Schökel, 2000, p. 131):

E acordou, como de um sono, o Senhor, como um homem forte gritando por vinho.

\subsection{OXIMORO}

É a junção de duas palavras, ou expressões, que são semanticamente incompatíveis e que, ligadas, não possuem nenhuma referência à realidade, ou seja, não podem ser interpretadas literalmente. (Cf. Watson, 1984, p. 312) O oximoro, que também é chamado de paradoxismo, pode ser utilizado para produzir ironia (cf. Schökel, 2000, p. 161), ou produzir "choque intelectual" no leitor/ouvinte a fim de causar reflexão, como em Pv 28:19 (cf. Salisbury, 2004, p. 19): 
Jó 3:11 também apresenta um oximoro em sua construção. Nesse verso o lugar da vida é proposto como um túmulo; o nascer (sair do ventre) ligado com o morrer, criando um duplo paradoxismo (cf. Fokkelman, 1998, p. 166):

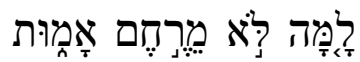

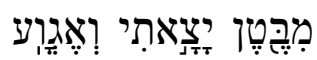

Por que não do útero morri?

e do ventre saí e faleci?

\subsection{ANÁFORA}

Uma espécie de repetição técnica, onde uma palavra ou grupo de palavras é reproduzida no início de cada linha do poema. (Cf. Watson, 1984, p. 276, n 6) Robert Alter chama a atenção para essa "repetição incrementada", pois a palavra ou frase repetida é complementada por palavras ou frases diferentes, criando uma tensão permanente entre "similaridade e diferença, reiteração e acréscimo". (Alter, 1985, p. 64)

Alter ainda argumenta que, como a cada palavra ou frase repetida um novo complemento é adicionado, o significado da repetição nunca é igual, pois a "cor", ou tonalidade, do que está rodeando a anáfora é sempre diferente. (Cf. Ibid.) Ele cita o SI 13:2 como um exemplo do uso da anáfora (cf. Ibid., p. 6364):

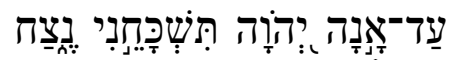

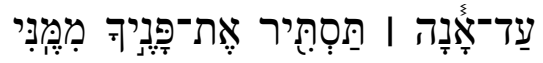

Até quando YHWH, se esquecerás de mim para sempre? Até quando esconderás Tua face de mim?

\subsection{HIPÉRBOLE}


O uso do discurso exagerado em algum sentido é um recurso retórico típico do estilo da literatura do Oriente Médio antigo. Seu uso cria imagens vívidas e causa impacto no leitor/ouvinte. Muitas vezes ocorre ao lado de metáforas e símiles e dessa forma é abundante no texto bíblico, principalmente em comparações. (Cf. Watson, 1984, p. 316-317; Schökel, 2000, p. 168)

Em Cântico dos Cânticos, por exemplo, as metáforas e comparações estão carregadas de sentido hiperbólico, muito por causa do foco dos amantes em enaltecerem um ao outro. Alguns exemplos são (cf. Hunt, 2008, p. 44-47):

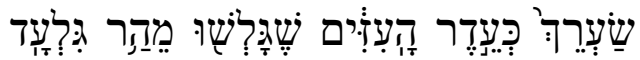

seu cabelo como um rebanho de cabras que descem do monte de Gileade (Ct 4:1)

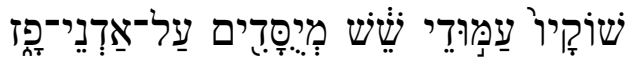

suas pernas são colunas de alabastro colocadas sobre bases de ouro (Ct 5:15)

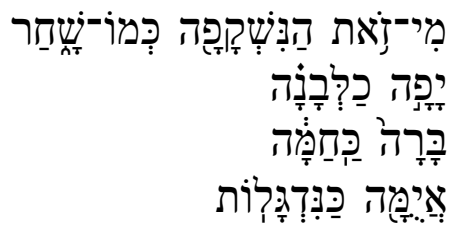

Quem é essa que olha para baixo como o amanhecer, bela como a lua, brilhante como o sol, terrível como um exército com bandeiras? (Ct 6:10)

\subsection{EUFEMISMO}

O eufemismo é o uso do discurso indireto, ou seja, quando procura se dizer algo de maneira sutil, discreta. Geralmente, em uma construção 
eufemística, acaba por se fazer emprego da perífrase também. A função é evitar indelicadeza, mas também adornar o texto. (Cf. Hunt, 2008, p. 35)

Essa figura de linguagem é problemática por não haver concordância sobre aquilo que está velado no texto ou mesmo sobre as possíveis referências linguísticas de uma palavra. (Cf. Ibid.) Por exemplo, em Cântico dos Cânticos 4:16, no final do verso, a personagem feminina convida o amado para vir ao jardim e comer os frutos do mesmo:

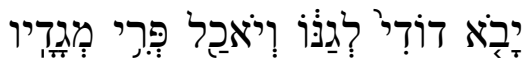

que venha meu amado para seu jardim e coma os frutos excelentes dele.

O uso de metáforas nos versos anteriores, em que o amante compara a amada a um jardim (v. 12) e menciona os frutos da amada ( $v$ 13), parece criar uma possibilidade de duplo entendimento nesse verso, e parece apontar não só para o que foi dito, literalmente, mas para aquilo que ficou não dito, principalmente. (Cf. Bloch e Bloch, 1998, p. 14)

Enfim, a linguagem de Cântico dos Cânticos, recheada de referências a flores, frutos, perfumes, etc., está conectada com a associação desses elementos à sexualidade e fertilidade em diversas línguas e costumes ao longo dos tempos. (Cf. Hunt, 2008, p. 104-105)

Outro verso que parece fazer um uso de eufemismo é Ct 7:3 ${ }^{308}$, na primeira parte do verso, onde se lê:

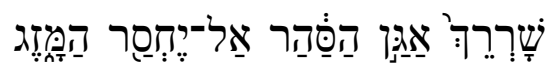
teu umbigo é tigela oval, nunca falta vinho misto.

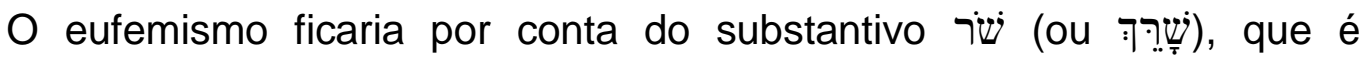
traduzido por umbigo (cf. Stoop-van Paridon, 2005, p. 366; Long, 1993, p. 264265; etc.), mas que alguns alegam ser uma referência à vulva. (Cf. Alter, 1985,

${ }^{308} \mathrm{Na}$ ARA, Ct 7:2. 
p. 197; Landy, 1983, p. 89-90; Pope, 1977, p. 617-618; etc.) Embora a discussão seja primariamente linguística, pode-se abordar a metáfora do verso pelo aspecto visual, ou seja, o umbigo é, de certa forma, um eufemismo do orgão genital feminino. (Longman III, 2001, p. 194-195; Exum, 2005, p. 233234; Long, 1993, p. 265-266)

\subsection{SARCASMO E IRONIA}

As duas figuras de linguagem são similares e se interpõem. $O$ sarcasmo é o uso de linguagem irônica ou depreciativa com o fim de insultar ou escarnecer. O intuito é depreciar. (Cf. Salisbury, 2004, p. 20) Quando a zombaria advém de alguém próximo, seu efeito é "mais penetrante, mais doloroso, parte mais o coração", por isso não é surpresa que a divindade, por exemplo, direcione sarcasmo ao povo, como em Jr 7:21 (cf. Schökel, 1984, p. 160):

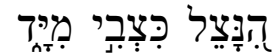

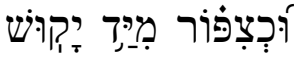

Salva-te como uma gazela da mão como o pássaro da mão do caçador. ${ }^{309}$

A ironia é a percepção de incongruência e pode ser verbal ou situacional. A intenção no uso da ironia é humorística e o caso mais comum é quando se usa uma palavra querendo significar exatamente o seu oposto. (Cf. Salisbury, 2004, p. 20-21) Essa figura de linguagem é mais comum na Bíblia Hebraica do que se reconhece e isso acontece por diversas razões, mas especialmente porque 0 texto hebraico não apresenta marcações extralinguísticas que tornem claro os momentos irônicos. Assim, nota-se sua utilização apenas quando o sentido literal de um texto não faz sentido (no caso verbal) ou pelo contexto se subentende um caso de ironia. (Cf. Watson, 1984,

\footnotetext{
309 Sua tradução foi: "Add your burnt offerings to your sacrifices and eat the flesh!" (Schökel,
} 1984, p. 160) 
p. 306-307) Carolyn Sharp coloca da seguinte maneira: "Ironia persuade por desinformar de maneira complexa. [...] a audiência precisa perceber que a comunicação não é confiável em algum aspecto crucial". ${ }^{310}$ (Sharp, 2009, p. 1)

Em Provérbios, uma das vítimas da ironia/sarcasmo é o ocioso (ou vagabundo), como em Pv 26:15 (cf. Schökel, 2000, p. 165):

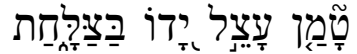

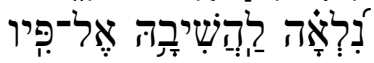

O vagabundo enterra sua mão no prato cansa-o trazê-la de volta a sua boca. ${ }^{311}$

Cântico dos Cânticos 8:8-10 há uma construção irônica, já que os irmãos da mulher, a quem chamam de "irmãzinha", dizem que ela não possui seios ( $v$. 8) e se propõe a fazê-la mais valiosa construindo um acampamento de prata sobre ela (v.9). Logo na sequência, entretanto, ela mesmo se pronuncia e diz que seus seios são como torres aos olhos do amado. (Cf. Hunt, 2008, p. 63)

\subsection{PalaVRas-chaVe}

As palavras-chave são aquelas que se sobressaem no texto por seu significado em relação ao discurso feito ou por sua repetição exaustiva. Seu uso produz um nível considerável de coesão e unidade textual e pode marcar também o início ou final de seções (quando mudam as palavras-chave ou quando uma que está sendo usada deixa de sê-lo). A palavra-chave não precisa necessariamente ser repetida (às vezes podem ser sinônimos), mas sua aparição precisa ser marcante. (Cf. Watson, 1984, p. 287-288)

A função desse elemento poético, além da unidade, é direcionar o leitor/audiência para o tema principal do poema e indicar uma possível estrutura, já que tudo circularia em torno dessa palavra-chave. (Cf. Dorsey,

\footnotetext{
310 "Irony persuades by misdirecting in a complex way. (...) the audience needs to perceive that communication is unreliable in some crucial respect."

${ }^{311}$ A divisão em versos segue a sugestão de Schökel (1984, p. 165). Sua tradução foi: "The idler puts out his hand to the dish / but is too tired to raise it to his mouth."
} 
1999, p. 32-33) Em Cântico dos Cânticos, uma série de palavras-chave se repete ao longo do poema: vinho, filhas de Jerusalém, etc. (Cf. Murphy, 1979, p. 439-440)

\subsection{MUdANÇA DE PESSOA}

A mudança de pessoa no meio de um discurso poético (da primeira pessoa do singular para a segunda ou terceira, sempre se referindo ao mesmo agente, ou feminino e masculino) é um recurso frequente e marca, entre outras coisas, o início de uma nova seção e fim da precedente, além de, em alguns casos, indicar o ápice do poema. Essa mudança pode ocorrer abruptamente. (Cf. Dorsey, 1999, p. 21-23; Wendland e Zogbo, 2000, p. 50-53)

Meir Sternberg, inclusive, menciona a mudança de pessoa (e também de espaço, de tempo e de gênero) como uma marca distintiva entre poesia e narrativa bíblica. (Cf. Sternberg, 1987, p. 72) Um exemplo de mudança de pessoa pode ser notado no SI 46, onde, rodeado por referências a Deus na terceira pessoa, repentinamente, a voz do próprio Deus se faz ouvir, acrescentando ao poema dramaticidade e indicando seu ponto alto (cf. Salisbury, 2004, p. 27):

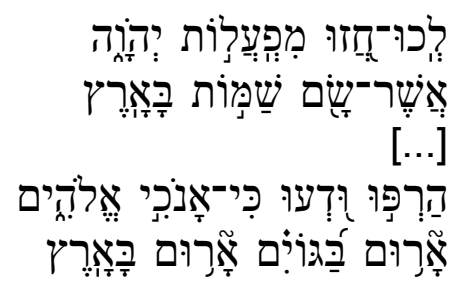

Vinde, vede as obras de YHWH, que colocou desolações na terra.

$[\ldots]$

Aquietai-vos e sabei que Eu sou Deus, exaltado entre as nações, exaltado na terra. ${ }^{312}$

${ }^{312} \mathrm{SI} 46: 9$ e 11. 


\section{CONCLUSÃo}

No primeiro capítulo desse trabalho, a proposta foi a de apresentar um panorama geral do debate a respeito da PHB e foi demonstrado que, apesar da argumentação de James Kugel contra a ideia de poesia na $\mathrm{BH}$, grande parte 
dos estudiosos entende existir tal conceito e que o mesmo não se restringe ao uso da palavra 'poesia'.

Ao mesmo tempo, a ausência de formulações sobre poesia serve, justamente, para estimular o esforço e a imaginação do estudioso em descortinar o que está implícito nos próprios poemas. (Cf. Lichtenstein, 1984, p. 108) Ou seja, sem 'Poética', resta ao poema bíblico estabelecer sua própria definição e descrição em si mesmo.

Essa definição passa, como visto, em um primeiro momento, pela diferenciação entre prosa e poesia, aonde se concluiu que a poesia não é totalmente dividida pela prosa, como se houvesse um muro entre elas (cf. Buber e Rosenzweig, 1994, p. 130), mas que se dá pela concentração de certos elementos, como o paralelismo, talvez o elemento poético mais relevante.

No segundo capítulo, conforme a sugestão inicial, foi traçado um recorte histórico de análise do paralelismo, iniciando com Lowth $(\mathrm{s} / \mathrm{d})$, na chamada época moderna do estudo de poesia bíblica (cf. Harris, 2004, p. 1) - ainda que, como demonstrou-se brevemente, o conceito de paralelismo seja anterior.

Nesse recorte histórico, revelou-se a evolução do estudo do paralelismo desde Lowth. Em um primeiro momento houve a busca por definições e nomenclaturas para descrever a 'descoberta'. Decorrente dessa primeira fase, a segunda trouxe um certo questionamento da terminologia inicial, embora os estudiosos desse período tenham reafirmado o conceito do paralelismo enfaticamente, principalmente pela comparação entre o texto da $\mathrm{BH}$ com outros manuscritos antigos, em sumério e acadiano. Também nesse período iniciouse a expansão terminológica do paralelismo, que com Lowth se limitava a três (sinônimo, antitético e sintético).

Ainda no início da década de 80, O'Connor busca romper com o padrão que vinha se estabelecendo no estudo do verso hebraico e inova nas nomenclaturas e nas descrições dos fenômenos poéticos da BH. Entretanto, sua inovação terminológica não encontra eco posterior. James Kugel, também no início da mesma década, produz um arrazoado que questiona mais do que nomenclaturas e definições, mas o próprio conceito de poesia dentro do texto hebraico bíblico. Contudo, as afirmações quanto à inexistência da PHB, que tornam Kugel único e sem precedentes, parecem contrastar com sua 
reafirmação do conceito de paralelismo, ainda que ele deixe claro sua insatisfação com os enunciados anteriores do mesmo.

Aparentemente na contramão de O'Connor e Kugel, Wilfred Watson produz um manual de PHB, mais preocupado com o estilo do que com aspectos linguísticos e literários. Watson aproxima-se da PHB com metodologia clara e busca definir os elementos dela de maneira ampla e precisa. Cada um dos elementos poéticos da $\mathrm{BH}$ é analisado sob a ótica comparativa (poesia ugarítica e acadiana) e ilustrado com uma gama de exemplos textuais.

Robert Alter e Meir Weiss, que também produziram estudos na década de 80, buscam simplificar. Suas descrições do paralelismo e da PHB são elaboradas em termos gerais e sem o uso de vasta terminologia sendo que Weiss, inclusive, critica abertamente o uso da mesma. Alter analisa porções variadas de textos poéticos da $\mathrm{BH}$ e procura demonstrar sempre uma de suas principais teses: o paralelismo é uma estrutura de intensificação, ou seja, não há um paralelo exato, mas um incremento do que é dito. As conclusões de Alter se aproximam, como visto, das de Kugel.

Ainda na prolífica década de 80, Adele Berlin desenvolve seu argumento sobre o paralelismo a partir de uma perspectiva linguística, tendo as teorias de Jakobson como base. Suas conclusões e exemplos buscam apontar o grande alcance do paralelismo na linguagem, já que ele ativaria os principais aspectos da linguagem. A partir de Berlin, os estudos sobre PHB e paralelismo são reafirmações ou ampliações do que já havia sido dito.

No capítulo terceiro, demonstrou-se que o uso do paralelismo produz (ou realça) alguns produtos: quiasmo, métrica, pares de palavras e metáfora. $A$ intenção foi indicar que tanto diretamente, como no caso do quiasmo, um tipo de paralelismo específico, quanto indiretamente, como no caso da metáfora, que existe por si só, o paralelismo acaba por direcionar/influenciar o funcionamento de outros elementos poéticos importantes e, em certo sentido, essenciais para o funcionamento da PHB.

No último capítulo listou-se uma série de elementos poéticos que ocorrem dentro da $\mathrm{BH}$ e que são importantes para a compreensão da poesia hebraica. Ali, o importante foi destacar definições simples e exemplos que ilustrassem as mesmas. 
Como parte das conclusões desse trabalho, entendemos que a PHB não é separada da prosa bíblica por "uma parede não escalável" (Buber e Rosenzweig, 1994, p. 130), o que quer dizer que, embora partilhem de elementos estruturais comuns, como o paralelismo, a diferenciação se dá pela presença mais marcante e intensa dos mesmos no caso da PHB. Também concluímos que se nos prendermos a categorias e gêneros no sentido da literatura ocidental clássica perderemos o sentido da poética hebraica. (Cf. Fisch, 1990, p. 4)

Concluímos que o paralelismo, apontado por Weiss e outros como o elemento mais característico da poesia bíblica, é um recurso amplo e complexo. Ele não somente organiza e dá ritmo ao texto poético da $\mathrm{BH}$, como, além disso, acentua a presença de outros recursos poéticos. Mas mesmo apontando a variedade de partes componentes da Poesia Hebraica Bíblica, é importante terminarmos por ressaltar que "o fenômeno da poesia bíblica continua maior do que a soma de suas partes". (Lichtenstein, 1984, p. 124)

\section{REFERÊNCIAS BIBLIOGRÁFICAS}

AleXANDER, Patrick et al. SBL Handbook of Style: for ancient near eastern, biblical, and early Christian studies. Peabody, MA: Hendrickson Publishers, 1999.

Alter, Robert. The Poetic and Wisdom. In: BARTON, John (ed.) The Cambridge Companion to Biblical Interpretation. New York: Cambridge University Press, 1998. p. 226-240. 
As Características da Antiga Poesia Hebraica. In: Alter, Robert e KeRMODE, Frank (eds.) Guia Literário da Bíblia. Trad. Raul Fiker. São Paulo: Editora Unesp, 1997. p. 653-666.

The Art of Biblical Poetry. New York: Basic Books, 1985.

Andersen, Francis I.; Forbes, A. Dean. Prose Particle Counts of the Hebrew Bible. In: MeYERS, Carol L. e O'CONNOR, M. (eds.) The Word of the Lord Shall Go Forth: essays in honor of David Noel Freedman in celebration of his sixtieth birthday. Winona Lake, IN: Eisenbrauns, 1983. p. 165-183.

ARANDA, Mariano Gómez. El Comentario de Abraham Ibn Ezra al Libro de Job: edición crítica, tradución y estudio introductorio. Madrid: Consejo Superior de Investigaciones Científicas, 2004. (Literatura Hispano-Hebrea, 6).

BARTON, John. Reading the Old Testament: method in biblical study. $2^{a}$ ed. Louisville, KY: Westminster John Knox Press, 1996.

Berlin, Adele. Reading Biblical Poetry. In: Berlin, Adele e Brettler, Marc Zvi (eds.) The Jewish Study Bible. New York: Oxford University Press, 2004. p. 2097-2104.

Introduction to Hebrew Poetry. In: The New Interpreter's Bible. v. 4. Nashville: Abingdon Press, 1996. p. 301-315.

University Press, 1985.

. Poetics and Interpretation of Biblical Narrative. Sheffield, England: Almond Press, 1983. (Bible and Literature Series, 9).

BLAU, Joshua. Phonology and Morphology of Biblical Hebrew: an introduction. Winona Lake: Eisenbrauns, 2010. (Linguistic Studies in Ancient West Semitic)

Bloch, Ariel; BLOCH, Chana. The Song of Songs: a new translation with an introduction and commentary. Los Angeles: University of California Press, 1998.

Briggs, Charles A. Hebrew Poetry. In: Hebraica, vol. 2, $n^{\circ}$ 3. Chicago: The University of Chicago Press, 1886. p. 164-170.

Brown, F.; Driver, S.; Briggs, C. The Brown-Driver-Briggs Hebrew and English Lexicon. Peaboy, MA: Hendrickson Publishers, 2000.

Buber, Martin; RosenzWeIG, Franz. Scripture and Translation. Indianapolis: Indiana University Press, 1994. (Indiana Studies in Biblical Literature).

ClineS, David J. A. (ed.) The Concise Dictionary of Classical Hebrew. Sheffield: Sheffield Phoenix Press, 2009.

The Parallelism of Greater Precision. In: FolLIS, Elaine R. (ed.) Directions in Biblical Hebrew Poetry. Sheffield, England: Sheffield Academic Press, 1987. p. 77-100. (Journal for the Study of the Old Testament Supplement Series, 40). 
CLOETE, Walter Theophilus Woldemar. Versification and Syntax in Jeremiah 2-25: syntactical constraints in hebrew colometry. Atlanta: Scholars Press, 1989. (SBL Dissertation Series, 117).

CoOPER, Alan. Two Types of Linguistic Poetics. In: WeIss, Meir. The Bible from within: the method of total interpretation. Jerusalem: The Magna Press, 1984.

CRoss, Frank Moore. Studies in the Structure of Hebrew Verse: the prosody of Lamentations 1:1-22. In: MEYERS, Carol L. e O'CONNOR, M. (eds.) The Word of the Lord Shall Go Forth: essays in honor of David Noel Freedman in clebration of his sixtieth birthday. Winona Lake, IN: Eisenbrauns, 1983. p. 129155.

Cross, Frank Moore; Freedman, David Noel. Studies in Ancient Yahwistic Poetry. Missoula, MT: Scholars Press, 1975. (SBL Dissertation Series, 21).

CuRTIS, Edward L. Some Features of Hebrew Poetry. In: The Old Testament Student, vol. 5, $\mathrm{n}^{\circ}$ 1. Chicago: The University of Chicago Press, 1885. p. 1-8.

DORSEY, David A. The Literary Structure of the Old Testament: a commentary on Genesis-Malachi. Grand Rapids, Ml: Baker Books, 1999.

DotAN, Aron (ed.) Biblia Hebraica Leningradensia: prepared according to the vocalization, accents, and masora of Aaron ben Moses ben Asher in the Leningrad Codex. Peabody, MA: Hendrickson Publishers, 2001.

Elliger, K. e RUdolph, W. (eds.) Biblia Hebraica Stuttgartensia. 5 $5^{\text {a }}$ ed. Stuttgart: Deutsche Bibelgesellschaft, 1997.

Exum, J. Cheryl. Song of Songs: a commentary. Louisville: Westminster John Knox Press, 2005. (The Old Testament Library)

FISCH, Harold. Poetry with a Purpose: biblical poetics and interpretation. Indianapolis: Indiana University Press, 1990.

FOKKELMAN, J. P. Reading Biblical Poetry: an introductory guide. Louisville, KY: Westminster John Knox Press, 2001.

Major Poems of the Hebrew Bible: at the interface of hermeneutics and structural analysis. vol 1: Ex 15, Deut 32, Job 3. Assen: Van Gorcum, 1998.

Freedman, David Noel. Pottery, Poetry, and Prophecy: studies in early Hebrew poetry. Winona Lake, IN: Eisenbrauns, 1980.

Galbraith, Jeffrey Alan. A Quantitative Analysis of the Parallelistic Structures in Hebrew Poetry. 1981. 206 f. Tese (Ph.D. em Antigo Testamento) - Boston University, Boston, 1981.

Geller, Stephen A. Parallelism in Early Biblical Poetry. Missoula, MT: Scholars Press, 1979. (Harvard Semitic Monographs, 20)

Gillingham, S. E. The Poems and Psalms of the Hebrew Bible. New York: Oxford University Press, 1994. (The Oxford Bible Series) 
GRAY, George Buchanan. The Forms of Hebrew Poetry: considered with special reference to the criticism and interpretation of the Old Testament. s/l: Hodder and Stoughton, 1915.

Greenberg, Moshe. Introduction to Hebrew. Englewood Cliffs, NJ: PrenticeHall, 1965.

Grossberg, Daniel. Centripetal and Centrifugal Structures in Biblical Poetry. Atlanta: Scholars Press, 1989. (SBL Monographs Series, 39).

Halabé, Rahel. Biblical Hebrew the Practical Way. Jerusalem: The Hebrew University Magna Press, 2011.

HARRIS, Robert A. Discerning Parallelism: a study in northern French medieval Jewish biblical exegesis. Providence, RI: Brown University, 2004. (Brown Judaic Studies, 341).

HARSHAV, Benjamin. Explorations in Poetics. Stanford, CA: Stanford University Press, 2007.

HeIDEGGER, Martin. On the Way to Language. New York: HarperOne, 1982.

Holladay, William L. 'Hebrew Verse Structure' Revisited (I): which words "count"? In: Journal of Biblical Literature, vol. 118, $\mathrm{n}^{\circ} 1$. Atlanta: Society of Biblical Literature, 1999. p. 19-32.

HRUSHOVSKI, Benjamin. Note on the Systems of Hebrew Versification. In: CARMI, T. (ed.) The Penguin Book of Hebrew Verse. Londres: Penguin Books, 1981. p. 57-72.

HUNT, Patrick. Poetry in the Song of Songs: a literary analysis. New York: Peter Lang, 2008. (Studies in Biblical Literature, vol. 96)

Jakobson, Roman. Lingüística, Poética e Cinema. São Paulo: Editora Perspectiva, 1970.

. Grammatical Parallelism and its Russian Facet. In: Language, vol 42, $\mathrm{n}^{\circ}$ 2. Washington: The Linguistic Society of America, 1966. p. 399-429.

JeRO, Christopher. The Verbal System of Biblical Hebrew Poetry: the morphosyntactic role of internal aspect. 2008. 220 f. Tese (Ph.D. em Religião) Hebrew Union College, Institute of Jewish Religion, Cincinnati, 2008.

JoüON, P.; MuRAOKA, T. A Grammar of Biblical Hebrew. 2 ${ }^{a}$ ed. Roma: Gregorian \& Biblical Pres, 2009.

KIRSChbaum, Saul; Blatyta, Dora Fraiman; Langer, Eliana Rosa; AraúJo, Reginaldo Gomes de. Transliteração do Hebraico para Leitores Brasileiros. São Paulo: Ateliê Editorial, 2009.

KoeHler, Ludwig; Baumgartner, Walter. The Hebrew and Aramaic Lexicon of the Old Testament: Study Edition. 2 vol. Boston: Brill, 2001.

KORPEL, Marjo C. A.; DE MOOR, Johannes C. Fundamentals of Ugaritic and Hebrew Poetry. In: MeER, Willem van der e Moor, Johannes C. de (eds.) The 
Structural Analysis of Biblical and Canaanite Poetry. Sheffield, England: Sheffield Academic Press, 1988. p. 1-61. (Journal for the Study of the Old Testament Supplement Series, 74).

Kosmala, Hans. Form and Structure in Ancient Hebrew Poetry: a new approach. In: Vetus Testamentum, vol. 14, $\mathrm{n}^{\circ}$ 4. Leiden: Brill, 1964. p. 423445.

KRAŠOVEC, Jože. Antithetic Structure in Biblical Hebrew Poetry. Leiden: Brill, 1984. (Supplements to Vetus Testamentum, XXXV)

KUGEL, James L. The Idea of Biblical Poetry: parallelism and its history. New Haven: Yale University Press, 1981.

LACOCQUE, André. Romance She Wrote: a hermeneutical essay on Song of Songs. Eugene, OR: Wipf \&Stock Publishers, 1998.

LAFERRIÈRE, Daniel. Sign and Subject: semiotic and psychoanalytic investigations into poetry. Lisse, England: The Peter de Ridder Press, 1978. (Studies in Semiotics, 14).

LANDY, Francis. Poetics and Parallelism: some comments on James Kugel's The Idea of Biblical Poetry. In: Journal for the Study of the Old Testament, vol 28. 1984. p. 61-87.

Paradoxes of Paradise: identity and difference in the Song of Songs. Sheffield: The Almond Press, 1983. (Bible and Literature Series)

Leatherman, Donn W. An Analysis of Four Current Theories of Hebrew Verse Structure. 1998. 455 f. Tese (Ph.D. em Religião) - Faculty of Religious Studies, McGill University, Montreal, 1998.

LiCHTEnSteIn, Murray H. Biblical Poetry. In: Holtz, Barry W. (ed.) Back to the Sources: reading the classic Jewish texts. New York: Simon \& Schuster Paperbacks, 1984. p. 105-127.

LONG, Gary Alan. Simile, Metaphor, and the Song of Songs. 1993. $380 \mathrm{f}$. Tese (Ph.D. em Near Eastern Languages and Civilizations) - The University of Chicago, Chicago, 1993.

LONGMAN III, Tremper. Song of Songs. Grand Rapids, MI: William B. Eerdmans Publishing Company, 2001. (The New International Commentary on the Id Testament)

LOWTH, Robert. Lectures on the Sacred Poetry of the Hebrews. London: Kessinger Publishing, s/d.

LUCAS, Ernest C. Exploring the Old Testament: a guide to the Psalms \& Wisdom literature. v. 3. Downers Grove, IL: InterVarsity Press, 2003.

LUNN, Nicholas P. Word-Order Variation in Biblical Hebrew Poetry: differentiating progmatics and poetics. Eugene, OR: Wipf \& Stock Publishers, 2006. (Paternoster Biblical Monographs). 
MEEK, Theophile James. The Structure of Hebrew Poetry. In: The Journal of Religion, vol. 9, $\mathrm{n}^{\circ}$ 4. Chicago: The University of Chicago Press, 1929. p. 523550.

MeIR, Amira. On the Study of Pentateuchal Poetry. In: ElLENS, J. Harold et al (eds.) God's Word for Our World: biblical studies in honor of Simon John De Vries. vol 1. New York: T\&T Clark International, 2004. p. 96-113.

Melamed, E. Z. Break-Up of Stereotype Phrases as an Artistic Device in Biblical Hebrew. In: RABIN, Chaim (ed.) Scripta Hierosolymitana: Studies in the Bible. v. 8. Jerusalem: The Magna Press, 1961. p. 115-153.

Merwe, Christo H. J. Van Der; Naudé, Jackie A.; Kroeze, Jan H. A Biblical Reference Grammar. Sheffield: Sheffield Academic Press, 1999. (Biblical Languages: Hebrew, 3).

MURPHY, Roland E. The Song of Songs: a commentary on the book of Canticles or the Song of Songs. Minneapolis: Fortress Press, 1990. (Hermeneia).

The Unity of the Song of Songs. In: Vetus Testamentum, vol. 29, $\mathrm{n}^{\circ}$ 4. Leiden: Brill, 1979. p. 436-443.

NicCaccl, Alviero. The Biblical Verbal System in Poetry. In: Fassberg, Steven E. E HURVITZ, Avi (eds.) Biblical Hebrew in Its Northwest Semitic Setting: typological and historical perspectives. Jerusalem: Magna Press, 2006. p. 247268.

Analysing Hebrew Poetry. In: Journal for the Study of the Old Testament, vol. 74. Sheffield, England: Sheffield Academic Press, 1997. p. 7793.

NOEGEL, Scott B. Janus Parallelism in the Book of Job. Sheffield, England: Sheffield Academic Press, 1996. (Journal for the Study of the Old Testament Supplement Series, 223).

e Rendsburg, Gary A. Solomon's Vineyard: literary and linguistic Studies in the Song of Songs. Atlanta: Society of Biblical Literature, 2009. (Ancient Israel and Its Literature, 1).

O'CONNOR, M. Hebrew Verse Structure. Winona Lake, IN: Eisenbrauns, 1980.

The Contours of Biblical Hebrew Verse: an afterword to 'Hebrew Verse Structure'. In: O'CONNOR, M. Hebrew Verse Structure. $2^{\mathrm{a}}$ ed. Winona Lake, IN: Eisenbrauns, 1997. p. 631-650.

OGden, Graham S. Poetry, Prose, and their Relationship: some reflections based on Judges 4 and 5. In: WENDLAND, Ernst R. (ed.) Discourse Perspectives on Hebrew Poetry in the Scriptures. New York: United Bible Society, 1994. p. 1-27. (UBS Monographs Series, 7).

Overland, P. Chiasm. In: Longman III, Tremper e EnNs, Peter (eds.) Dictionary of the Old Testament: wisdom, poetry \& writings. Downers Grove, IL: IVP Academic, 2008. p. 54-57. 
OWENS, John Joseph. Analytical Key to the Old Testament. 4 vol. Grand Rapids, MI: Baker Book House, 1989.

PARTRIDGE, Kathryn J. A Discourse Study of Tense Aspect in Narrative Sections of Hebrew Poetry. 1995. 142 f. Dissertação (Master of Arts em Lingüística) - The University of Texas, Arlington, 1995.

Petersen, David L.; Richards, Kent Harold. Interpreting Hebrew Poetry. Minneapolis: Fortress Press, 1992. (Old Testament Series).

POPE, Marvin H. Song of Songs: a new translation with introduction and commentary. New York: Doubleday, 1977. (The Anchor Bible, vol 7c)

RAABE, Paul, R. Psalm Structures: a study of Psalms with Refrains. Sheffield, England: Sheffield Academic Press, 1990. (Journal for the Study of the Old Testament Supplement Series, 104).

Revelt, E. J. Pausal Forms and the Structure of Biblical Poetry. In: Vetus Testamentum, vol. 31, n² 2. Boston: Brill, 1981. p. 186-199.

RoBerTS, D. Phillip. "Let me see your form": seeking poetic structure in the "Song of Songs". 2001. 810 f. Tese (Ph.D. em Teologia) - Westminster Theological Seminary, Glenside, PA, 2001.

Rogers, Nancy Louise. Poetic Revelation: the relationship between parallelism and metaphor in Biblical Hebrew Poetry. 2010. 227 f. Tese (Ph.D. em Teologia) - Fordham University, New York, 2010.

RotH, Wolfgang M. W. The numerical sequence $x / x+1$ in the Old Testament. In: Vetus Testamentum, vol. 12, $n^{\circ}$ 3. Leiden: Brill, 1962. p. 300-311.

Salisbury, Murray. Biblical Hebrew Poetry. In: Biblical Hebrew Poetry, Hebrew University of Jerusalem, Jerusalem, 04-29/07, 2004. (Apostila de aula)

SCHÖKEL, Luis Alonso. A Manual of Hebrew Poetics. Roma: Editrice Pontificio Istituto Biblico, 2000. (Subsidia Biblica, 11).

Dicionário Bíblico Hebraico-Português. Trad. Ivo Storniolo e José Bortolini. São Paulo: Paulus, 1997.

SHARP, Carolyn J. Irony and Meaning in the Hebrew Bible. Bloomington: Indiana University Press, 2009. (Indiana Studies in Biblical Literature)

Sternberg, Meir. The Poetics of Biblical Narrative: ideological literatures and the drama of reading. Bloomington: Indiana University Press, 1987.

Stoop-VAN PARIDON, P. W. T. The Song of Songs: a philological analysis of the Hebrew book Shir HaShirim. Herent: Peeters, 2005. (Ancient Near Eastern Studies, supplement 17).

TATU, Silviu. The Qatal//Yiqtol (Yiqtol//Qatal) Verbal Sequence in Semitic Couplets: a case study in systemic functional grammar with applications on the Hebrew psalter and ugaritic poetry. Piscataway, NJ: Gorgias Press, 2008. (Gorgias Ugaritic Studies, 3). 
Tsumura, David Toshio. Vertical Grammar of Parallelism in Hebrew Poetry. In: Journal of Biblical Literature, vol. 128, $\mathrm{n}^{\circ}$ 1. Atlanta: Society of Biblical Literature, 2009. p. 167-181.

TUCKER JR, W. D. Psalms 1: book of. In: LONGMAN III, Tremper e ENNS, Peter (eds.) Dictionary of the Old Testament: wisdom, poetry \& writings. Downers Grove, IL: IVP Academic, 2008. p. 578-583.

VANCE, Donald R. Toward a Poetics of Biblical Hebrew Poetry: the question of meter. 1997. 521 f. Tese (Ph.D. em Teologia) - Faculties of The lliff of Theology e The University of Denver, Denver, 1997.

WATSON, Wilfred G. E. Traditional Techniques in Classical Hebrew Verse. Sheffield, England: Sheffield Academic Press, 1994. (Journal for the Study of the Old Testament Supplement Series, 170).

. Problems and Solutions in Hebrew Verse: a survey of recent work. In:

Vetus Testamentum, vol. 43, n 3. Boston: Brill, 1993. p. 372-384.

Classical Hebrew Poetry: a guide to its techniques. Sheffiled, England: Sheffield Academic Press, 1984.

WATTERS, William R. Formula Criticism and the Poetry of the Old Testament. Berlin: Walter de Gruyter, 1976.

WEISS, Meir. The Bible from within: the method of total interpretation. Jerusalem: The Magna Press, 1984.

WendLand, Ernst R. The Discourse Analysis of Hebrew Poetry: a procedural outline. In: WendLAND, Ernst R. (ed.) Discourse Perspectives on Hebrew Poetry in the Scriptures. New York: United Bible Society, 1994. p. 1-27. (UBS Monographs Series, 7).

WendLand, Ernst R.; ZogBo, Lynell. Hebrew Poetry in the Bible: a guide for understanding and for translating. New York: United Bible Societies, 2000.

YODER, Perry B. A - B Pairs and Oral Composition in Hebrew Poetry. In: Vetus Testamentum, vol. 21, $n^{\circ}$ 4. Boston: Brill, 1971. p. 470-489. 